\title{
Rwanda: Enhanced Initiative for Heavily Indebted Poor Countries- Completion Point Document
}

This paper was prepared by staff of the International Monetary Fund and the World Bank in connection with the Executive Board's consideration of Rwanda's Enhanced Initiative for Heavily Indebted Poor Countries. It is based on the information available at the time it was completed on March 25, 2005. The views expressed in this document are those of the staff team and do not necessarily reflect the views of the government of Rwanda or the Executive Board of the IMF.

The policy of publication of staff reports and other documents by the IMF allows for the deletion of market-sensitive information.

To assist the IMF in evaluating the publication policy, reader comments are invited and may be sent by e-mail to publicationpolicy@imf.org.

Copies of this report are available to the public from

International Monetary Fund • Publication Services

$70019^{\text {th }}$ Street, N.W. • Washington, D.C. 20431

Telephone: (202) 623-7430 • Telefax: (202) 623-7201

E-mail: publications@imf.org • Internet: http://www.imf.org

Price: $\$ 15.00$ a copy

\section{International Monetary Fund Washington, D.C.}





\section{INTERNATIONAL MONETARY FUND AND \\ INTERNATIONAL DEVELOPMENT ASSOCIATION}

\section{RWANDA \\ Enhanced Heavily Indebted Poor Countries (HIPC) Initiative Completion Point Document}

Prepared by the Staffs of the International Monetary Fund and the International Development Association

Approved by Sharmini Coorey and Mark Plant (IMF)

and Gobind Nankani and Danny Leipziger (IDA)

March 25, 2005

Contents Page

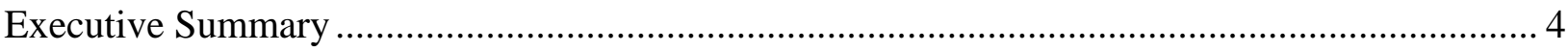

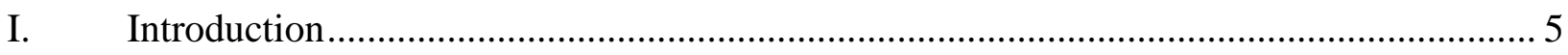

II. Progress on the Conditions For Reaching the Completion Point ................................. 5

A. Rwanda's Poverty Reduction Strategy and Use of Enhanced HIPC Debt Relief.......... 6

B. Macroeconomic Stability ................................................................................. 9

C. Structural Reforms in the Tea Sector .................................................................. 11

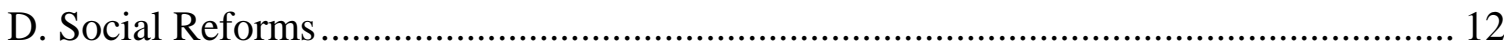

E. Reform Progress Beyond Completion Point Triggers ............................................ 13

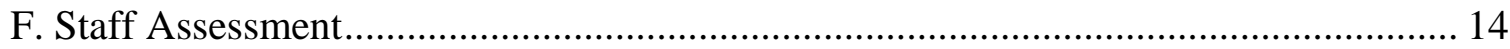

III. Delivery of Debt relief and Long-term Debt Sustainability ....................................... 14

A. Reconciliation of Decision Point Debt Data ..................................................... 14

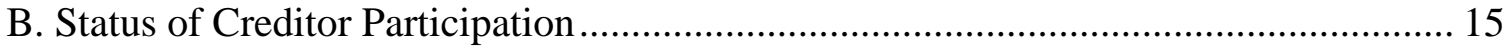

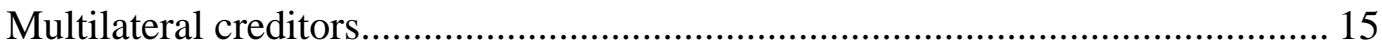

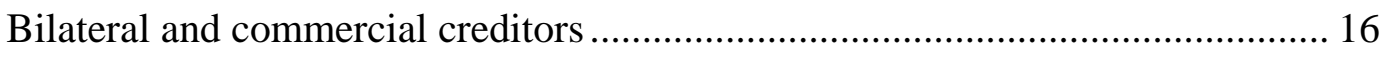

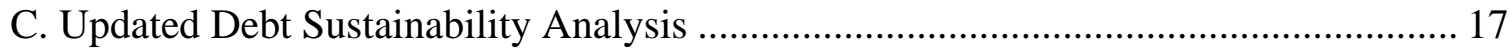

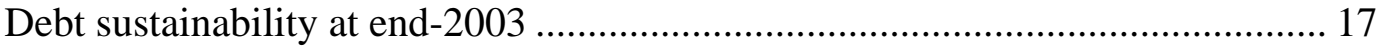

Debt sustainability over the period 2004-23 ................................................ 18

D. Sensitivity Analysis and Long-Term Debt Sustainability ..................................... 20

Scenario 1: Terms of trade shock .............................................................. 20

Scenario 2: Reduction of external grants .................................................. 21

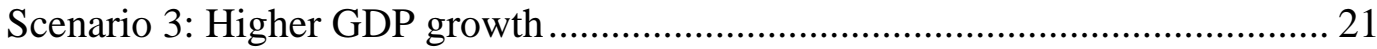

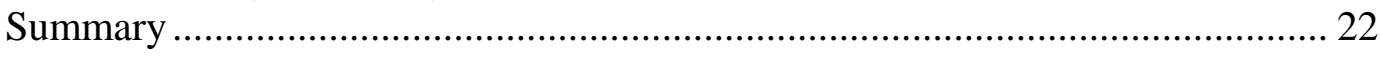


IV. Consideration of a Topping-Up of Enhanced HIPC Initiative Assistance ........................... 22

A. Decomposition of the Increase in the NPV of Debt-to-Exports Ratio......................... 23

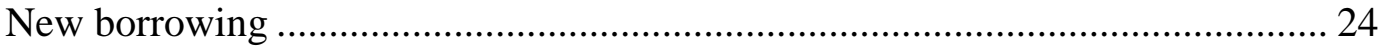

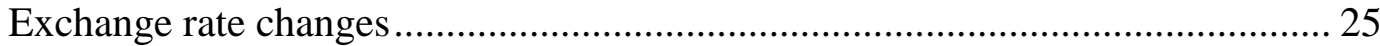

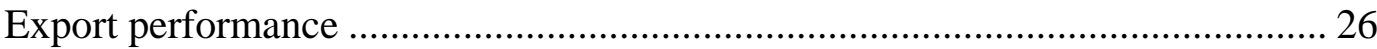

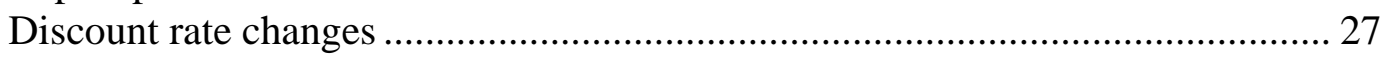

B. Other Considerations Affecting Rwanda's Economic Circumstances....................... 30

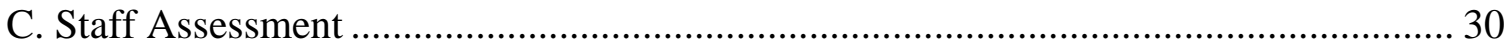

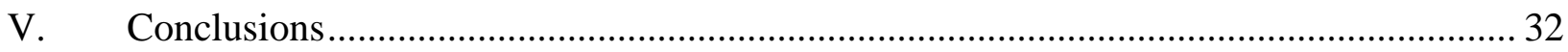

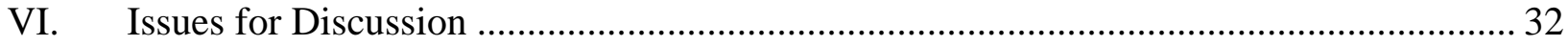

A. Policy Coordination and Debt Strategy ........................................................... 57

B. Data Recording and Reporting .......................................................................... 58

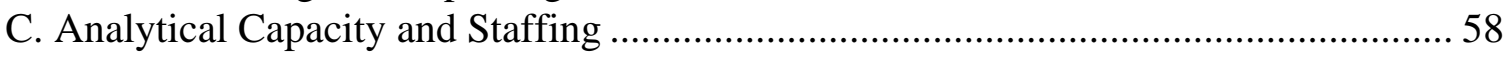

Boxes

1. Status of Triggers for the HIPC Floating Completion Point .........................................

2. Selected Structural Reforms, 2000-04 ............................................................................ 14

3. Macroeconomic Assumptions Underlying the Debt Sustainability Analysis at the

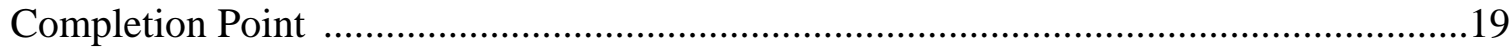

4. Factors Underlying Rwanda's Export Performance ..................................................28

Figures

1. Projected NPV of Debt-to-Exports Ratio, 2003-19 ................................................19

2. Percentage Deviation of Export Volumes from Decision Point

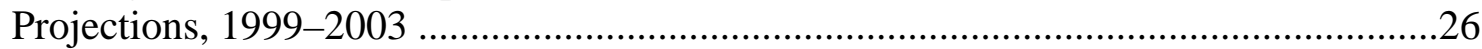

3. Percentage Deviation of Export Prices from Decision Point Projections, 1999-2003 ................................................................................27

4. Change in Export Prices Since Decision Point, (Moving Price Indices

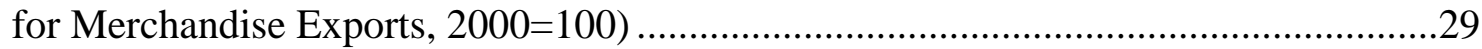

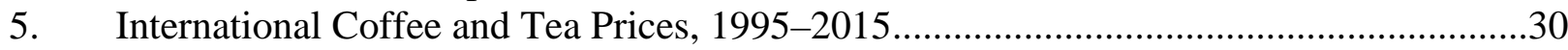

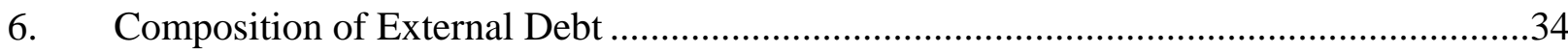

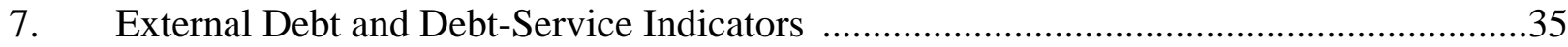

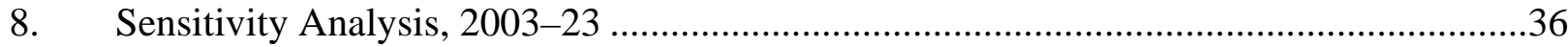

Tables

1. Priority Spending, 1998-2004 f........................................................................... 9

2. Selected Economic and Financial Indicators, 1999-2004 ….......................................10

3. Breakdown of the Increase of NPV of Debt-to-Exports Ratio ..................................25

4. Structure of External Debt by Currency Denomination ..................................................26

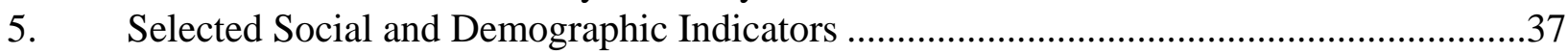

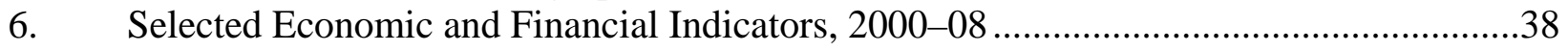


7. Observance of Quantitative and Structural Performance Criteria and Benchmarks Under PRGF Arrangement, 2001-04 ............................................................................39

8. Nominal and Net Present Value of External Debt Outstanding at End-1999 ...................42

9. Status of Creditor Participation for HIPC Assistance as Approved at the Decision

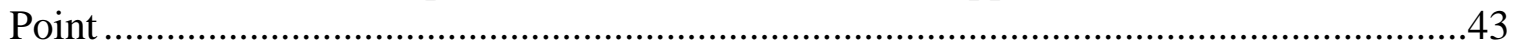

10. Delivery of IDA Assistance Under the Enhanced HIPC Initiative.................................44

11. Delivery of IMF Assistance Under the Enhanced HIPC Initiative................................45

12. Paris Club Creditors' Delivery of Debt Relief Under Bilateral Initiatives Beyond

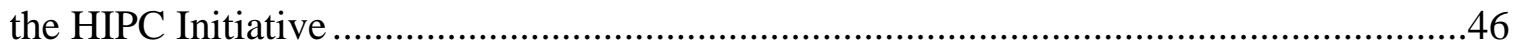

13. Discount Rate and Exchange Rate Assumptions at the Decision Point and at the Completion Point ..................................................................................................4

14. Nominal and Net Present Value of External Debt Outstanding at End-2003 ..................48

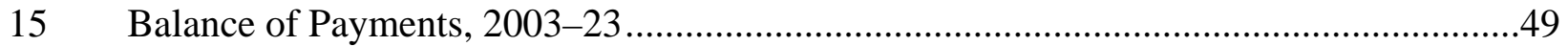

16. Main Assumptions Used for the DSA at the Completion Point, 2003-23 ......................50

17. Net Present Value of External Debt, 2003-23 .........................................................51

18. External Debt Service After Full Implementation of Debt-Relief Mechanisms,

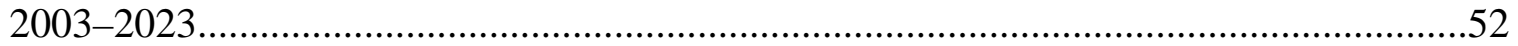

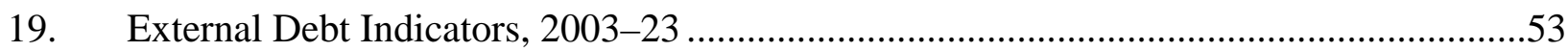

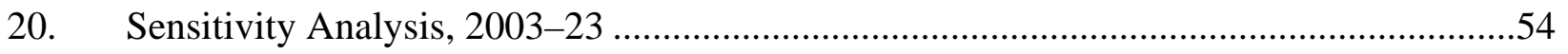

21. Enhanced HIPC Initiative Assistance Levels and Possible Topping-Up at

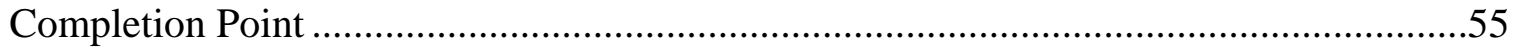

22. HIPC Initiative: Status of Country Cases Considered Under the Initiative,

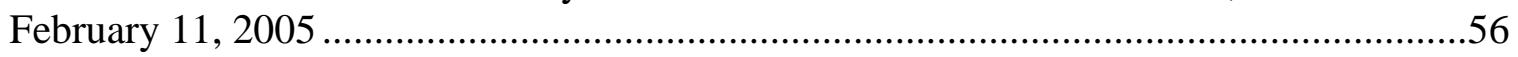

Appendices

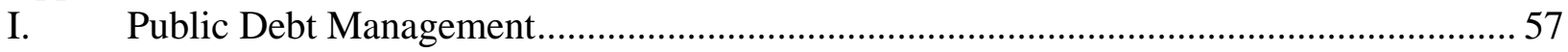

A. Policy Coordination and Debt Strategy ........................................................... 57

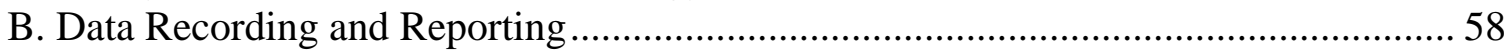

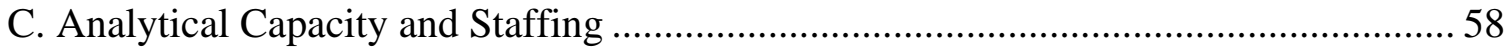

II. Debt Sustainability Analysis for Low Income Countries ....................................... 60 


\section{Executive Summary}

- In December 2000, the Executive Boards of the IMF and IDA agreed that Rwanda had met the requirements to reach the decision point under the enhanced HIPC Initiative. The debt sustainability analysis (DSA) based on end1999 data indicated at the time that a debt relief of US\$452.4 million in net present value terms (NPV) was required under the Initiative, to lower the NPV of debt-to-exports ratio to 150 percent.

- The staffs of IDA and the IMF are of the opinion that Rwanda has made satisfactory progress to reach the completion point under the HIPC

Initiative. All triggers have been met, except for the one with respect to the tea sector, which has not been fully implemented. In view of the strong performance in most policy areas, particularly in education and health where the completion point triggers have been surpassed, and given the completion of the fourth review under the PRGF arrangement, the staffs recommend a waiver of the trigger related to the tea sector.

- $\quad$ The staffs now project a substantial worsening of debt indicators compared with the projections made at the decision point. An updated DSA based on end-2003 data indicates that the NPV of debt-to-exports ratio at end-2003 after full delivery of HIPC assistance stood at 326 percent compared with 193 percent projected at the decision point. Moreover, despite ambitious assumptions regarding the degree of grant financing ( 83 percent of total financing with the remainder filled by loans on standard IDA terms), the revised ratio would peak at 343 percent in 2004 before declining to 171 percent by 2023. At the decision point the ratio was expected to drop below the 150 percent HIPC threshold in 2008 and stay below that threshold throughout the forecast period.

The staffs are of the view that the substantial deterioration in Rwanda's NPV of debt-to-exports ratio, compared with the decision point projections, is primarily attributable to fundamental changes in the country's economic circumstances due to exogenous factors. Lower export prices, changes in crosscurrency exchange rates, and a lower-than-expected concessionality of new borrowing were all unambiguously exogenous and outside the control of the authorities. Moreover, staffs have presented additional analysis establishing lower discount rates as an exogenous and fundamental factor causing a deterioration in Rwanda's NPV of debt-to-exports ratio. All these factors account for more than 50 percent of both the unanticipated and the total increase and thus provide sufficient justification for topping-up of debt relief at the completion point. In addition, the unanticipated increase of import prices compared with decision point projections can be expected to have a lasting negative impact on Rwanda's terms of trade and, consequently, its capacity to repay its debt. Taken together, these facts support the case that Rwanda meets the requirements for topping-up of HIPC assistance at the completion point. 


\section{INTRODUCTION}

1. In December 2000, the Executive Boards of the International Monetary Fund (IMF) and the International Development Association (IDA) agreed that Rwanda had met the requirements to reach the decision point under the Enhanced Heavily Indebted Poor Countries (HIPC) Initiative. ${ }^{1}$ At that time, a set of triggers was established for Rwanda to reach the floating completion point. This paper assesses Rwanda's progress in meeting those triggers, and seeks the Boards' approval of the HIPC completion point, including a waiver of one of the completion point triggers, and a topping-up of assistance under the Initiative.

2. At the decision point, the debt relief required to lower the NPV of debt-toexports ratio to the $\mathbf{1 5 0}$ percent threshold under the Enhanced HIPC Initiative was estimated to be US\$452.4 million in NPV terms. This relief represented a 71.3 percent reduction of Rwanda's debt, in NPV terms, after full use of traditional debt relief mechanisms. The Boards of the IMF and IDA also agreed to provide Rwanda with interim debt relief until Rwanda reached the floating completion point. As of end-2004, the IMF has delivered interim assistance in the amount of US\$20 million in nominal terms, and IDA has provided interim relief in the amount of US\$56.5 million. Rwanda has also benefited from interim debt relief from the African Development Bank Group (AfDB), the Arab Bank for Economic Development in Africa (BADEA), the OPEC Fund for International Development (OPEC Fund), the European Union, and Paris Club creditors.

3. The rest of the paper is organized as follows. Section II assesses Rwanda's progress in meeting the conditions for reaching the completion point. Section III discusses the current status of the delivery of HIPC debt relief and presents the results of an updated DSA based on end-2003 data. Section IV discusses considerations for a topping-up of the assistance under the Enhanced HIPC Initiative. The conclusions are summarized in Section V. Section VI presents issues for discussion.

\section{Progress on the Conditions For Reaching the Completion Point}

\section{Rwanda has made satisfactory progress in meeting the conditions for} reaching the completion point (Box 1). As set out in the decision point document, the conditions for reaching the completion point were (i) completion of a full Poverty Reduction Strategy Paper (PRSP), with satisfactory implementation for at least one year and budgetary savings from the HIPC Initiative used to increase expenditures in poverty reduction programs; (ii) maintenance of macroeconomic stability; (iii) progress in the reform of the tea sector; and (iv) the implementation of key social measures in education, health, and HIV/AIDS and the adoption and implementation of a gender action plan. All triggers have been met, except for the one with respect to the tea sector. Progress in the reforms of the tea sector has been satisfactory, but the trigger was not fully met as the

\footnotetext{
${ }^{1}$ See http://www.imf.org/external/np/hipc/2000/rwa/rwadp.pdf and http://www.worldbank.org/hipc, "Rwanda-Enhanced Heavily Indebted Poor Countries (HIPC) Debt Initiative Decision Point Document".
} 
authorities did not receive acceptable bids for the sale of one tea factory. The following sections present progress made by the government in fulfilling the completion point triggers.

\section{A. Rwanda's Poverty Reduction Strategy and Use of Enhanced HIPC Debt Relief}

\section{Following extensive consultations with civil society and other stakeholders,} the authorities finalized the PRSP in June 2002. ${ }^{2}$ The PRSP identifies six broad areas as priorities: (i) rural development and agricultural transformation; (ii) human development; (iii) economic infrastructure; (iv) good governance; (v) private sector development; and (vi) institutional capacity building.

\section{Implementation of the PRSP has been broadly satisfactory as described in} the annual progress reports (APRs). ${ }^{3}$ Using a wide set of financial, economic, and social indicators, the APRs highlighted improved performance in the social sectors, particularly in education and health, and progress in strengthening the overall institutional and legal framework, including in the financial sector. Great strides have also been made in donor coordination and dissemination of information. On the latter, steps have been taken to improve the capacity of the media to broaden participation and increase the dissemination of information by granting more private radio licenses. Moreover, the government enhanced the teaching capacities and curriculum at the School of Journalism and is developing a strategic plan for the media that was finalized at end-2004. However, the APRs also acknowledged policy slippages in 2003, slow progress in agricultural transformation and decentralization, as well as weaknesses in sectoral monitoring and reporting.

\section{Priority spending almost doubled between 1998 and 2001, when Rwanda} started to receive HIPC relief (Table 1). Specifically, priority spending stood at 2.8 percent of GDP in 1998 and increased to 4.0 percent by 2000, with more than 80 percent of expenditure going to education during those years. By 2001, priority spending had increased to 5.3 percent of GDP. This contrasts with an average of

\footnotetext{
${ }^{2}$ See "Rwanda-Poverty Reduction Strategy Paper_Joint Staff Assessment," Country Report No. 04/274 and www.worldbank.org Report No. 28350-RW (5/18/2004).

${ }^{3}$ See "Rwanda-Poverty Reduction Strategy Paper First Annual Progress Report—Joint Staff Assessment," Country Report No. 04/274 and IDA Report No. 28350-RW; and "Poverty Reduction Strategy Paper Second Annual Progress Report_Joint Staff Advisory Note" www.imf.org; and IDA No.-31679-RW, March 2005. In light of policy slippages in the second half of 2003, a supplement to the second APR covering the last six months of 2004 was issued on March 10, 2005, to document a one-year track record of satisfactory implementation of the PRSP (2004).
} 


\section{Box 1. Status of HIPC Completion Point Triggers}

\begin{tabular}{|l|}
\hline \multicolumn{1}{|c|}{ Triggers } \\
\hline PRSP: \\
(i) Completion of a full PRSP and satisfactory \\
implementation for at least one year as \\
evidenced by the Joint Staff Assessment of \\
the first annual progress report.
\end{tabular}

(ii) Budgetary savings from the Enhanced HIPC debt relief used to increase expenditures on poverty-reducing programs.

Macroeconomic framework: Maintenance of satisfactory macroeconomic stability as evidenced by satisfactory performance under the PRGF arrangement.

Structural reform: Progress in the reform of the tea sector, including privatization of at least two of the nine state-owned tea factories/estates in accordance with the strategy agreed in the context of the IDA's Economic Recovery Credit.

\section{Education sector:}

(i) increasing net primary school enrollment from 69 percent in 1999 to the target of 73 percent in 2001.

(ii) making operational at least 6 primary teacher training centers offering full-time and in-service training programs.

(i) the establishment of the framework for community participation in support of primary and secondary education.
Met. The full PRSP was finalized in June 2002 and discussed by the Boards in July 2002. The first PRSP Annual Progress Report (APR) was completed in June 2003 and the Joint Staff Assessment submitted to the Boards in May 2004. The second PRSP APR, covering mid2003 to mid-2004, was issued in November 2004 and a supplement to the APR covers the second half of 2004. A Joint Staff Advisory Note (JSAN) is issued together with this completion point document.

Met. Priority programs have been identified based on PRSP priorities. Increases in expenditures have been made for these programs in the budgets for 2001-04.

Met. Rwanda has broadly maintained macroeconomic stability since the decision point. In completing the fourth review under the PRGF arrangement, Rwanda has shown a satisfactory track record of policy implementation.

Not fully met. The reform of the policy and regulatory framework for tea is proceeding satisfactorily, although the authorities were not able to complete the sale of one tea factory despite good faith efforts.

A law to redefine the role of the state marketing board (OCIR-Thé) was adopted in 2003. OCIR-Thé's transition to this new role is ongoing. Prices are now negotiated between farmers and factories, based on production costs and world market conditions.

The sale transfer of Pfunda tea factory was completed in November 2004. Mulindi tea factory reached the point of sale in November 2004. However, during the negotiations, the government assessed that the proposed terms of sale were not beneficial to the industry and the economy. A new invitation to bid for Mulindi will be launched in 2005 with Phase II of the privatization covering 4 additional factories. Currently, the government is in the process of choosing the firm to act as transaction advisor for the second phase of privatization. Technical proposals have been received from potential firms, and are being assessed. Once a firm is chosen, the bidding process for the second phase will be launched and bidding is expected to start in the second half of 2005.

Met. Net primary school enrollment of 73 percent was achieved in 2001. Net enrollment is currently at 95 percent.

Met. In 2001/02, 11 Teacher Training Centers offering full time and in-service training became operational. However, their programs will need to be upgraded following the Teacher Deployment and Management reform expected in 2005-06.

Met. In 2001, the Ministry for Education (MINEDUC) decentralized the system of education. The framework for community participation in support of primary and secondary education has been established and is now operational. 


\begin{tabular}{|c|c|c|}
\hline & $\begin{array}{l}\text { the design and implementation of a } \\
\text { capacity-building program for the } \\
\text { management of education at the central and } \\
\text { decentralized levels. }\end{array}$ & $\begin{array}{l}\text { Met. A framework for the capacity-building program has been } \\
\text { designed, and implementation initiated. It will be revised to reflect } \\
\text { the results of the ongoing civil service reform. }\end{array}$ \\
\hline \multicolumn{3}{|c|}{ Health Sector: } \\
\hline & $\begin{array}{l}\text { the full staffing and equipping of at least } \\
50 \text { percent of the district health centers; }\end{array}$ & $\begin{array}{l}\text { Met. Estimates suggest that, as of February } 2003 \text {, as much as } \\
70 \text { percent of health centers have been equipped and fully staffed. }\end{array}$ \\
\hline & $\begin{array}{l}\text { the adoption and implementation of national } \\
\text { plans to reduce morbidity and mortality due } \\
\text { to malaria, and reduce infant mortality and } \\
\text { maternal mortality; and }\end{array}$ & $\begin{array}{l}\text { Met. The Roll Back Malaria Strategic Plan for } 2004-10 \text { has been } \\
\text { developed in collaboration with donors. Implementation is ongoing } \\
\text { with good progress in providing subsidized treatment, supporting } \\
\text { distribution of impregnated bed nets, building on preventive treatment } \\
\text { through other programs, and addressing drug resistance. }\end{array}$ \\
\hline & & $\begin{array}{l}\text { To reduce infant and child mortality the government will: (i) continue } \\
\text { strengthening the Expanded Program of Immunization which is } \\
\text { one of the strongest in Africa with DPT3 (diphtheria, pertusis, } \\
\text { tetanus) coverage rates of over } 96 \text { percent; and (ii) enhance the } \\
\text { Integrated Management of Childhood Illnesses to strengthen the } \\
\text { quality of care for children under five at both the clinical and } \\
\text { community levels. } \\
\text { The government is implementing its national Reproductive Health } \\
\text { Policy which focuses on: good motherhood and infant health, family } \\
\text { planning, STI management, adolescent health, and prevention and } \\
\text { care of sexual violence and empowerment of women. }\end{array}$ \\
\hline & $\begin{array}{l}\text { adoption and implementation of a } \\
\text { framework for the coordination of public, } \\
\text { private, and NGO health providers. }\end{array}$ & $\begin{array}{l}\text { Met. A framework is in place which details the nature of cooperation } \\
\text { between the ministry of health (MOH) and the private sector. The } \\
\text { goal is to encourage greater participation and integration of the } \\
\text { private sector into health districts. To this end, the MOH plans to } \\
\text { strengthen its regulatory and supervisory capacities, and will continue } \\
\text { to rely on contracts which stipulate the roles and responsibilities of } \\
\text { each party. }\end{array}$ \\
\hline \multicolumn{2}{|r|}{$\begin{array}{l}\text { HIV/AIDS: } \\
\text { The adoption and implementation of a new } \\
\text { Strategy and Action Plan for HIV/AIDS control } \\
\text { and prevention. }\end{array}$} & $\begin{array}{l}\text { Met. The 2002-06 HIV/AIDS Strategic Plan was prepared in a } \\
\text { participatory fashion, validated by all key stakeholders in } 2002 \text { and } \\
\text { adopted by the Cabinet on February 19, 2003. Implementation is solid } \\
\text { with notable progress in decentralizing the program to the provinces, } \\
\text { mobilizing all segments of the population, improving sentinel } \\
\text { surveillance, expanding HIV testing and increasing access to ARV } \\
\text { (Anti-Retroviral) treatment. }\end{array}$ \\
\hline \multicolumn{2}{|r|}{$\begin{array}{l}\text { : } \\
\text { The adoption and implementation of the } \\
\text { Comprehensive Action Plan to eliminate gender } \\
\text { disparities. }\end{array}$} & $\begin{array}{l}\text { Met. A Gender Action Plan (2001-05) was adopted by Cabinet at } \\
\text { end- } 2000 \text { and a Comprehensive Gender Action Plan to eliminate } \\
\text { gender disparities in the law was adopted in 2003. Implementation of } \\
\text { the Plan is ongoing, including gender sensitive reforms of the } \\
\text { Constitution, the Land law and the adoption of an anti-discrimination } \\
\text { law (adopted by the National Assembly in October } 2001 \text { outlawing } \\
\text { discrimination against anybody, "whether based on ethnicity, color of } \\
\text { the skin, physical features, origin, sex, opinions, religions" (Law No } \\
47 / 2001) \text { ). }\end{array}$ \\
\hline
\end{tabular}




\begin{tabular}{|c|c|c|c|c|c|c|c|}
\hline \multicolumn{8}{|c|}{$\begin{array}{l}\text { Table 1. Rwanda: Priority Spending, 1998-2004 } \\
\text { (In percent of GDP, unless otherwise stated) }\end{array}$} \\
\hline & 1998 & 1999 & 2000 & 2001 & 2002 & 2003 & 2004 \\
\hline Total priority spending & 2.8 & 3.9 & 4.0 & 5.3 & 6.2 & 6.9 & 8.5 \\
\hline Education & 2.2 & 3.2 & 3.2 & 3.5 & 3.9 & 4.2 & 4.0 \\
\hline Health & 0.4 & 0.5 & 0.6 & 0.7 & 0.8 & 0.6 & 1.0 \\
\hline Agriculture & 0.0 & 0.0 & 0.0 & 0.2 & 0.3 & 0.2 & 0.2 \\
\hline Export promotion & 0.0 & 0.0 & 0.0 & 0.0 & 0.0 & 0.0 & 0.4 \\
\hline Transport and communication & 0.0 & 0.0 & 0.0 & 0.1 & 0.3 & 0.4 & 0.3 \\
\hline Infrastructure (energy and water) & 0.0 & 0.0 & 0.0 & 0.0 & 0.2 & 0.0 & 1.1 \\
\hline Common Development Fund (CDF) & 0.0 & 0.0 & 0.0 & 0.0 & 0.1 & 0.4 & 0.3 \\
\hline Other $1 /$ & 0.2 & 0.2 & 0.2 & 0.9 & 0.5 & 1.0 & 1.3 \\
\hline \multicolumn{8}{|l|}{ Memorandum items: } \\
\hline HIPC relief & 0.0 & 0.0 & 0.0 & 1.4 & 1.5 & 1.3 & 1.4 \\
\hline Total expenditure (billions of RF) & 117.4 & 126.5 & 131.7 & 158.1 & 174.6 & 216.0 & 275.4 \\
\hline Nominal GDP (billions of RF) & 621.3 & 644.9 & 705.7 & 754.3 & 825.0 & 905.3 & 1054.3 \\
\hline
\end{tabular}

Sources: Rwandese authorities; and IMF and IDA staff estimates.

1/ This category includes, inter alia, spending on internal affairs, local government, commerce, and youth and sports.

31/2 percent of GDP during 1998-2000, and represents an increase of 1.8 percentage points by 2001 relative to the average after the start of HIPC relief (which provided increased resources of, on average, 1.4 percentage points of GDP). Since 2001, the coverage of priority spending was extended and has increased again, by close to 60 percent, to reach 8.5 percent of GDP in 2004. This increase reflects a slightly higher allocation to education and health, as well as a focus on new priorities such as infrastructure and decentralization, and, in 2004, electricity and export promotion. Since 2002, priority spending has been guided by the PRSP.

\section{Substantial improvements in expenditure management are safeguarding} priority spending. Most importantly, since 1999, the government has maintained the policy of protecting social sector budget allocations from cuts during the course of the fiscal year; and military spending has progressively been reduced, which has also enabled a reallocation of resources to priority areas. Moreover, since the 2002 budget cycle, expenditures have been classified in all ministries according to programs and subprograms, expected outputs, activities and inputs; and, as of 2003, budget preparation has been based on sectoral strategy notes prepared by line ministries. Recent achievements in public expenditure management also include the adoption of a mediumterm economic framework linking the sectoral strategies to the budget, improvements to the cash management system, and computerization of budget preparation and reporting. While an organic budget law (recently submitted to parliament) is expected to further strengthen budgetary control and transparency, significant capacity building in line ministries and local government is needed for its implementation.

\section{B. Macroeconomic Stability}

9. Rwanda has broadly maintained macroeconomic stability since reaching the decision point (Table 2). After experiencing strong growth and low-consumer price 
inflation over the period 1999-2002, economic performance weakened in the second half of 2003, with bad weather leading to a poor harvest for major crops and looser-thanexpected fiscal and monetary policies causing inflationary pressures and an accelerated depreciation of the exchange rate. In 2004, driven by the construction and services sectors, growth resumed and consumer price inflation (excluding food and energy) was around a moderate 5 percent. The level of central bank reserves has continuously provided a comfortable cushion to absorb unexpected shocks.

Table 2. Rwanda: Selected Economic and Financial Indicators, 1999-2004

\begin{tabular}{|c|c|c|c|c|c|c|}
\hline & 1999 & 2000 & 2001 & 2002 & 2003 & 2004 \\
\hline \multicolumn{7}{|l|}{ GDP (percentage change) } \\
\hline Real GDP growth & 7.6 & 6.0 & 6.7 & 9.4 & 0.9 & 4.0 \\
\hline Consumer prices (end of period) & 2.1 & 5.8 & -0.2 & 6.2 & 7.7 & 10.2 \\
\hline \multicolumn{7}{|l|}{ Central government budget (percent of GDP) } \\
\hline Total revenue (excluding grants) & 9.9 & 9.7 & 11.4 & 12.2 & 13.5 & 13.9 \\
\hline Total expenditure and net lending & 19.6 & 18.7 & 21.0 & 21.2 & 23.9 & 26.1 \\
\hline Domestic fiscal balance (excluding demobilization spending) & -3.5 & -2.3 & -2.2 & -3.8 & -4.7 & -5.3 \\
\hline \multicolumn{7}{|l|}{ Money and credit (percentage change, end of period) } \\
\hline Domestic credit & 12.8 & 0.7 & 0.3 & -4.0 & 19.7 & -22.6 \\
\hline Broad money & 6.5 & 14.3 & 9.2 & 11.4 & 15.2 & 12.6 \\
\hline \multicolumn{7}{|l|}{ External trade (percentage change) } \\
\hline Export volume & 12.7 & 19.7 & 73.2 & -10.0 & -12.5 & 26.8 \\
\hline Import volume & -5.3 & -14.6 & 2.3 & -6.3 & 1.1 & 4.6 \\
\hline Terms of trade (deterioration -) & -16.5 & 7.1 & -37.9 & -24.0 & 4.1 & 13.2 \\
\hline \multicolumn{7}{|l|}{ Balance of payments (percent of GDP) } \\
\hline Current account balance (excluding official transfers) & -16.9 & -16.5 & -15.9 & -16.6 & -19.2 & -18.1 \\
\hline Gross reserves (in months of imports of goods and services) & 4.7 & 5.4 & 6.0 & 6.3 & 5.0 & 5.8 \\
\hline
\end{tabular}

Sources: Rwandese authorities; and IMF and IDA staff estimates and projections.

10. The authorities, by and large, pursued prudent macroeconomic policies apart from temporary slippages in the second half of 2003. Domestic revenue, as well as grants, was significantly higher than projected at the decision point. ${ }^{4}$ At the same time, the domestic fiscal deficit gradually widened due to a strong increase in expenditure, which was largely spent on PRSP priorities. The remaining financing gap was filled by new external concessional loans (slightly lower than anticipated at the decision point) and domestic borrowing that remained below 0.5 percent of GDP during 2000-04. Monetary and exchange rate policies were broadly geared to achieving the inflation and international reserves targets. However, in the second half of 2003, policy

\footnotetext{
${ }^{4}$ Driven by tax reforms (introduction of a value-added tax in 2001, income tax reforms in 2003, and an overhaul of the tax administration in 2004), the revenue ratio increased gradually to about 14 percent of GDP in 2004 from about 10 percent in 1999. Grants were on average higher by 4.5 percent of GDP per year compared with the decision point projections.
} 
implementation weakened, with unprogrammed government outlays, including on elections, goods and services, as well as a large hotel project. ${ }^{5}$

11. While there were slippages in the program in the second half of 2003, the implementation of the PRGF-supported program through end-2003 and in the course of 2004 was broadly on track. In 2001, delays in reaching agreement on the 2002 budget and the medium-term fiscal framework led to the expiration of the previous ESAF/PRGF without disbursement of the final tranche, and caused a temporary lapse in interim relief from the IMF under the HIPC Initiative. However, a new PRGF arrangement was approved in August 2002 and the first review completed in June 2003. The developments discussed in the preceding paragraph led to a delay in the IMF Board discussion of the second and third reviews, which were completed in June 2004. Since then, there has been considerable improvement in policy implementation, evidenced by the staff's recommendation to complete the fourth review, based on an established sixmonth track record of successful policy implementation.

\section{Structural Reforms in the Tea Sector}

\section{Progress in the reform of the tea sector has been satisfactory, although}

slower than anticipated. Steps have been taken to redefine the government's role in the tea sector, aimed at preparing the institutional framework to support a privatized tea industry. In particular, a law redefining the role of OCIR-Thé, the government body regulating the tea sector, was passed in 2003. Instead of being involved in all aspects of operation and finance, OCIR-Thé is now providing extension activities to improve the capacity of smallholders and facilitate their access to inputs. Most importantly, OCIRThé no longer sets prices, which are now determined based on negotiated agreements with farmers' associations and representatives from tea factories, and beginning in 2004, the government included a price premium for the quality of tea harvested in order to improve incentives to farmers. Moreover, OCIR-Thé will gradually start focusing on policy and strategy development, collection and dissemination of market information, enforcing standards, and providing incentives for improved tea quality and exports.

\section{Although substantial progress was made toward reforms in the tea sector,} the full privatization of two tea factories was only partially concluded; thus, the completion point trigger was not fully met. Both the Pfunda and Mulindi tea factories were brought to the point of sale. ${ }^{6}$ However, a sales agreement was reached only with

\footnotetext{
${ }^{5}$ The financing of a hotel project by the domestic banking sector contributed to a higher-than-programmed monetary expansion in the second half of 2003.

${ }^{6}$ Corresponding to the legal definition that was used under the tranche conditions for the Institutional Reform Credit. Specifically, "bring to the point of sale" would be defined as having: (i) completed an evaluation of the stocks of Mulindi tea factory, on the basis, inter alia, of an evaluation of its assets and liabilities; (ii) prepared a prospectus for distribution to prospective buyers; (iii) solicited offers for the purchase of share capital; (iv) evaluated any such offers and selected successful bidders; and (v) invited the successful bidders to enter into good faith negotiations.
} 
respect to Pfunda. For the Mulindi factory, the government and the investor could not reach an agreement, because the investor wanted to negotiate terms which went below the list price, to a level unacceptable to the government. Mulindi is to be put on the market again in 2005 , along with 4 other factories. ${ }^{7}$ The government is reviewing the privatization process and framework to inform the next round of tea factory privatizations. ${ }^{8}$

\section{Social Reforms}

\section{Rwanda has implemented all social sector reform triggers for reaching the completion point:}

- In the education sector, net primary school enrollment is now at 95 percent, substantially above the target of 73 percent, and nearly twice as many teacher colleges were made operational as was required under the trigger. Moreover, the framework for community participation of primary and secondary education is now operational and a sector-wide approach has been adopted for a framework to build capacity in the management of education at the primary and secondary levels, including a regular stock-taking exercise conducted jointly by the Ministry of Education (MINEDUC), provincial and district authorities, donors, and parentteacher associations. ${ }^{9}$

- In the health sector, the government has succeeded in staffing and equipping a significantly higher percentage of district health centers than required under the completion point trigger (70 percent instead of 50 percent). The Roll Back Malaria Strategic Plan for 2004-10 has been developed and adopted in collaboration with donors; implementation is ongoing with good progress in providing subsidized treatment, supporting distribution of impregnated bed nets, and addressing drug resistance. Moreover, with immunization rates now at 96 percent according to official WHO/UNICEF data, progress has been made in reducing the incidence of communicable diseases, and the share of births attended by qualified health personnel has increased by 3 percentage points. Finally, the management and governance framework to support a dynamic health system based on NGOs anchored in grassroots activities and focused on co-financing

\footnotetext{
${ }^{7}$ As part of the actions that were monitored under the World Bank's Institutional Reform Credit, the government's rationale for re-launching the bid for Mulindi was considered justifiable and progress in the sector judged satisfactory.

${ }^{8}$ The government will undertake a re-examination of the privatization of Pfunda and Mulindi, designed as pilots for privatization in the sector. Lessons learned will inform the process for privatizing the remaining tea factories including Mulindi, scheduled for privatization in 2005. The process to choose a firm that will oversee the privatization process has already been initiated. Once a firm is chosen, the bidding process for the second phase will be launched in the second half of 2005.

${ }^{9}$ A revised action plan that incorporates changes from the civil service reform related to teacher training, recruitment, deployment, and professional development is scheduled to be adopted by mid-2005.
} 
with strong community involvement has been implemented successfully. In particular, to strengthen capacity, a new incentive package has been designed to entice staff to move to rural areas.

- $\quad$ Regarding the fight against HIV/AIDS, a multi-sectoral approach has been adopted and the availability of essential drugs has been maintained at close to 90 percent of all available essential drugs over the past few years due to community-managed revolving drug funds and an independently managed central purchasing store.

- $\quad$ A Gender Action Plan (2001-05), adopted by Cabinet in 2000, is under implementation, including dissemination of information and sensitization of the government and NGOs. It has been complemented by a Comprehensive Gender Action Plan (adopted in 2003) to eliminate gender disparities in the legal framework.

\section{E. Reform Progress Beyond Completion Point Triggers}

\section{Progress made with structural and social reforms over and above the} completion point triggers is documented in the Annual Progress Reports (APRs), as well as in a supplementary note to the second APR and addressed in the Joint Staff Assessment (JSA) and a Joint Staff Advisory Note (JSAN) (Box 2). Particularly noteworthy was the progress in reestablishing the critical elements of an effective state through the adoption of a new Constitution in May 2003, followed by presidential elections in August and legislative polls in September-October. Moreover, substantial progress was made in addressing governance issues, including by strengthening the office of the Auditor General and overhauling tax policy and administration. Some of the reforms, notably the privatization of a commercial bank, were also supported under the recent Institutional Reform Credit, which assessed progress in government's overall reform program as satisfactory.

\begin{tabular}{|c|c|}
\hline \multicolumn{2}{|c|}{ Box 2: Selected Structural Reforms, 2000-04 } \\
\hline $\begin{array}{l}\qquad \text { Money and Banking } \\
\text { Introduction of weekly foreign exchange auctions (2001) } \\
\text { Full audits of three commercial banks (2002) } \\
\text { First external audits of the National Bank of Rwanda } \\
\text { (2002) } \\
\text { Privatization of two banks (2004) }\end{array}$ & $\begin{array}{l}\text { Computerization of tax data management (2000) } \\
\text { Introduction of Medium-Term Economic Framework } \\
(2000) \\
\text { Introduction of VAT (2001) } \\
\text { Revision of tax code (2002) } \\
\text { Creation of Large Taxpayer Department (2004) }\end{array}$ \\
\hline $\begin{array}{l}\text { Trade Relations } \\
\text { Entry into COMESA (2003) } \\
\text { Adoption of the Revised Internal Trade Act (2000) }\end{array}$ & $\begin{array}{l}\text { Privatization } \\
\text { Establishment of Private Sector Federation (2000) } \\
\text { Liberalization of the telecommunications sector (2001) } \\
\text { Private management of electricity utility (2003) } \\
\text { Establishment of Public Utilities Regulatory Agency } \\
(2002)\end{array}$ \\
\hline
\end{tabular}




\section{F. Staff Assessment}

16. In view of the strong performance in most policy areas, particularly in education and health where the completion point triggers have been surpassed, and given the completion of the fourth review under the PRGF arrangement, the staffs recommend a waiver for the nonobservance of the completion point trigger related to reforms in the tea sector that has not been fully met. In the case of the privatization of the Mulindi factory, the staffs assess that the authorities brought the factory in question to the point of sale and their rejection of the final bid was on reasonable grounds. Moreover, the staffs welcome the authorities' commitment to privatize all remaining factories and believe that the review of the privatization of Pfunda and Mulindi will result in a revision of the privatization process to improve the prospects for a successful and rapid privatization of the remaining factories. Also, other reforms in the tea sector, notably the restructuring of OCIR-The and redefinition of its role, have been proceeding in a satisfactory manner, as also noted under the Institutional Reform Credit.

\section{DELIVERY OF DEBT RELIEF AND LONG-TERM DEBT SUSTAINABILITY}

\section{A. Reconciliation of Decision Point Debt Data}

\section{The reconciliation of debt data at end-1999 confirmed the amount of} assistance under the enhanced HIPC Initiative approved at the time of the decision point (Table 8). To ensure the accuracy of the decision point calculations, IDA and IMF staffs, together with the Rwandese authorities, have reviewed the data used at the time. ${ }^{10}$ Revisions to debt and export data result in a decrease of the debt reduction needed to reach the 150 percent HIPC threshold for the NPV of debt-to-exports ratio from US\$452.4 million in NPV terms to US\$451.2 million, representing less than one percent of the targeted NPV of debt after HIPC relief. ${ }^{11}$ Given the marginal net revision to the calculated NPV of debt, the staffs have left unchanged their assessment of the required debt relief under the HIPC Initiative at the decision point, and the ensuing common reduction factor. ${ }^{12}$ The main revisions to the debt data were as follows:

\footnotetext{
${ }^{10}$ In updating the DSA, the staffs and the authorities reconciled 95 percent of the nominal debt data as of end-1999 with creditor statements from all multilateral and Paris Club creditors and from most non-Paris Club official bilateral creditors.

${ }^{11}$ The three-year, backward looking average of exports in 1999 was revised upward to US\$122.7 million from US\$121.2 million.

${ }^{12}$ Under the 2002 information reporting framework in the context of the HIPC Initiative, upward and downward adjustments of less than one percentage point in the targeted NPV of debt after HIPC assistance do not require a revision of the amount of assistance that had been calculated at the decision point. For the PRGF-HIPC Trust Instrument (Section III, paragraph 3(b)), the provision that permits a downward revision of HIPC assistance due to a recalculation of the decision point DSA only applies to commitments made from March 15, 2002 onward.
} 
- Multilateral creditors. The NPV of Rwanda's multilateral debt to IFAD and BADEA was revised upward by US $\$ 1.2$ million and US $\$ 1.4$ million, respectively. ${ }^{13}$

- Bilateral creditors. The NPV of Rwanda's bilateral debt after delivery of traditional debt relief was revised downward with respect to Austria (US\$1.1 million), Canada (US\$1.2 million), and France (US\$1.2 million), and upward with respect to Kuwait (US\$4.5 million). ${ }^{14,15}$

\section{B. Status of Creditor Participation}

\section{Creditors accounting for 95 percent of total HIPC Initiative debt relief} estimated at the decision point have given satisfactory financing assurances for the provision of their share of assistance. ${ }^{16}$

\section{Multilateral creditors}

19. All of Rwanda's multilateral creditors have agreed to provide their full share of assistance under the Enhanced HIPC Initiative. Debt relief from multilateral creditors amounts to US\$396.5 million in NPV terms (87.6 percent of the total HIPC debt relief). Interim relief has been provided by all creditors with the exception of the International Fund for Agricultural Development (IFAD), which has committed to provide its share of assistance once Rwanda reaches the completion point (Table 9).

- $\quad$ Assistance from IDA. Debt relief from IDA amounts to US\$227.5 million in NPV terms. It is delivered through a reduction of 88.4 percent of debt service falling due on disbursed and outstanding debt to IDA as of end-1999, over the period 2001-20 (Table 10). Total nominal debt-service savings from IDA amount to US\$404.7 million and interim assistance in the amount of US\$56.5 million has been delivered through end-2004.

\footnotetext{
${ }^{13}$ The revision for IFAD was due to the correction for the use of an inappropriate repayment profile to project debt service payments. In the case of BADEA, a revision was warranted on the basis of updated information on the stock of arrears consolidated in the 1998 rescheduling agreement.

${ }^{14}$ Rwanda's debt vis-à-vis Austria, Canada, and France was revised downward because of new information provided on the nominal stocks of debt. With respect to Kuwait, the debt was revised upward after correcting for the use of an inappropriate interest rate at the decision point.

${ }^{15}$ Several European Union loans were incorrectly classified as multilateral at the decision point. In February 2005, the Commission of the European Union, after consultation with its member states, notified staffs that these loans should be classified as bilateral to reflect the correct ownership status they had since 1978.

${ }^{16}$ In this section of the document, any reference to financial assurances or delivery of debt relief refers to HIPC assistance approved at the decision point.
} 
- $\quad$ Assistance from the IMF. Enhanced HIPC assistance from the IMF amounts to SDR 33.8 million in NPV terms (equivalent to US\$43.8 million). Of this amount, the IMF has already disbursed interim assistance of SDR 14.45 million as of end2004. The remaining IMF assistance (SDR 19.36 million) will be disbursed at the completion point, which is projected to cover, on average, over 50 percent of Rwanda's principal repayments falling due to the IMF during 2005-10 (Table 11).

- $\quad$ Assistance from the AfDB Group. Debt relief from the AfDB amounts to US\$75.0 million in NPV terms. Relief is being provided through an 80 percent reduction of debt service falling due on debt outstanding and disbursed as of end1999, until July 2025; total nominal debt-service savings will amount to US\$144 million, of which, US\$20.1 million have been delivered through end2004.

- $\quad$ Assistance from other multilaterals. Debt relief from BADEA amounts to US\$21.1 million in NPV terms. Part of BADEA's debt relief has been delivered through a concessional rescheduling of arrears as of end-1998 and the payments falling due in 1999 and 2000. The European Union is expected to deliver a total relief of US\$13.1 million in NPV terms. As of end-2004, the EU had provided interim assistance in the nominal amount of $€ 4.2$ million through the cancellation of debt service that fell due on identified loans. The OPEC Fund is expected to provide relief of US $\$ 4.7$ million in NPV terms; interim relief has been provided in the form of two concessional loans that have already been disbursed. ${ }^{17}$ All of the above creditors will provide the remainder of assistance, when Rwanda reaches the completion point.

\section{Bilateral and commercial creditors ${ }^{18}$}

\section{Paris Club creditors have agreed in principle to provide their share of assistance under the enhanced HIPC Initiative (US\$34.8 million in NPV terms).} Interim assistance has been provided through a flow treatment under Cologne terms, as agreed on March 7, 2002. In the corresponding agreed minute, participating Paris Club creditors declared their readiness in principle to provide their full share of assistance through a stock-of-debt operation at the completion point, provided Rwanda maintained satisfactory relations with the participating creditor countries. Bilateral agreements have been signed with all Paris Club creditors with the exception of France and Japan, with whom Rwanda has exchanged draft agreements. ${ }^{19}$ Most creditors have also indicated

\footnotetext{
${ }^{17}$ The funds from these loans were used to refinance outstanding arrears to the OPEC fund and to cover debt service payments to the OPEC Fund, on less concessional obligations, as they fall due.

${ }^{18}$ At the time of the decision point, Rwanda had some outstanding obligations to commercial creditors. This debt was subsequently taken over by a Paris Club creditor.

${ }^{19}$ The deadline for conclusion of bilateral agreements was extended to end-March 2005.
} 
that they would provide additional assistance beyond HIPC relief (Table 12), estimated at about US\$9.4 million in end-2003 NPV terms.

\section{Non-Paris Club bilateral creditors are expected to provide treatment} comparable to that of the Paris Club, with assistance under the enhanced HIPC Initiative amounting to US\$21.1 million in NPV terms. While none of these creditors has committed to provide assistance under the Initiative, some have already provided part of their assumed share of traditional debt relief. ${ }^{20}$ All non-Paris Club creditors are expected to provide their full shares of traditional debt relief, as well as Enhanced HIPC assistance at the completion point.

\section{Updated Debt Sustainability Analysis}

\section{Debt sustainability at end-2003}

22. The DSA included in the decision point document was updated jointly by the authorities and the staffs of the IMF and IDA, on the basis of end-2003 loan-by-loan debt data provided by the authorities. ${ }^{21}$ The exchange rates and interest rates used in the DSA are presented in Table 13.

\section{Based on a 98 percent reconciliation of the debt data, ${ }^{22}$ Rwanda's nominal stock of external debt reached US\$1.6 billion at end-2003, compared with} US\$1.3 billion at end-1999 (Figure 6, and Tables 8 and 14). Of the total nominal debt at end-2003, 88.3 percent was owed to multilateral creditors. IDA remains Rwanda's largest creditor, accounting for 58.1 percent of total outstanding debt at end-2003. Bilateral debt amounted to US\$183.7 million with US\$88.9 million due to Paris Club creditors and the remainder to other creditors. With the exception of US\$26.2 million, the entire stock of outstanding debt is official development assistance (ODA).

\section{The NPV of Rwanda's external debt at end-2003, after full delivery of the} assistance committed under the HIPC Initiative at the decision point, is estimated at US\$467.1 million, which is equivalent to 326 percent of exports, compared with a decision point projection of 193 percent. Taking into account the bilateral debt relief beyond HIPC Initiative assistance, the NPV of debt is further reduced to

\footnotetext{
${ }^{20}$ Libya has recently announced that it would not participate in the Enhanced HIPC Initiative. The other bilateral non-Paris Club creditors provide debt relief on a case-by-case basis. Regarding the provision of debt relief during the interim period, the People's Republic of China cancelled some of its loans representing US\$14.2 million in NPV terms, and Kuwait and Saudi Arabia provided debt relief through a stock rescheduling of all remaining maturities and arrears under ODA terms, representing US\$4.0 million and US\$10.3 million, respectively. The United Arab Emirates and Libya have not provided any debt relief so far. The debt simulations assume full participation of all creditors.

${ }^{21}$ This refers to the public and publicly guaranteed external debt outstanding and disbursed.

22 This corresponds to a full reconciliation of multilateral and an 83 percent reconciliation of bilateral debt data at end-2003.
} 
US\$457.7 million; this still represents 320 percent of exports-a ratio significantly above the 150 percent threshold defined under the Enhanced HIPC framework. ${ }^{23}$

\section{Debt sustainability over the period 2004-23}

\section{The long-term macroeconomic framework for the DSA has been revised to} account for new developments since the decision point (Box 3, and Tables 15 and 16). The most important changes compared with the original macroeconomic framework are as follows:

- $\quad$ Economic growth was revised downward from a flat 6 percent over the whole projection period to gradually increase from 4 percent in 2005 to 5.5 percent from 2011 onward. This revision reflects the (more conservative) assumption that productivity increases, resulting from government action to enhance productivity in agriculture, and more generally in the tradables sector, will be realized with a longer lag and to a lower extent than originally expected at the decision point.

- $\quad$ Export projections made at the decision point were also revised downward from an annual average growth rate of 11 percent for goods and services (in U.S. dollar terms) over the period 2000-19 to a long-term rate of 8 percent with an initial growth rate of 9 percent during 2005-13, to reflect the implementation of the export promotion strategy. These revisions mainly reflect more conservative volume growth assumptions (reflecting slower-than-anticipated productivity gains for merchandise exports); in the early years, growth is assumed to be driven mainly by the coffee and tea sectors, in particular through a shift toward higher quality products (green, flavored, and organic tea, as well as fully washed coffee). After production levels for these crops approach a steady state at around 2015 (approximated at the level of the outturn in the 1980s), further growth would be maintained by a strong performance of nontraditional exports.

- $\quad$ External financing made available in the form of both budget and project support is projected to amount, on average, to 12.3 percent of GDP during 200523 , with a 17 percent share covered by concessional borrowing on standard IDA terms. The revised macroeconomic framework thus assumes a higher share of future grant financing of 83 percent both compared with the actual turnout in recent years (an average grant share of 67 percent over 2001-04) and the expected average share of 80 percent at the decision point. This more positive outlook anticipates a prudent stance of the Rwandese authorities with respect to the contracting of new loans aimed at improving the country's sovereign debt outlook and an expected shift in creditor policies toward more grant financing for lowincome countries.

\footnotetext{
${ }^{23}$ Section IV on topping-up considerations presents a detailed analysis of the factors which contributed to the increase in the ratio.
} 


\section{Box 3. Macroeconomic Assumptions Underlying the Debt Sustainability Analysis at the Completion Point}

The baseline assumptions for the period 2004-23 are as follows:

Real GDP growth is projected to increase gradually from 4 percent in 2004 to reach 51/2 percent by 2011 as growth-enhancing sectoral strategies take effect and investment in human capital (health and education sectors) starts to pay off. Per capita GDP is projected to increase gradually from 1.2 percent in 2004 to reach 2.7 percent by 2011 as the population is expected to grow by 2.7 percent on average between 2004 23.

Inflation is projected to fall to 6 percent in 2005 and stay at 4 percent from then onward.

Exports of goods and services would grow at about 9 percent until 2013 in U.S. dollar terms as the export promotion strategy takes effect and stabilize thereafter at about 8 percent. Imports of goods and services would increase by 7 percent on average over the period 2005-23, mostly due to growing demand for capital good imports from the private sector.

Central government tax revenue is projected to increase gradually from 14 percent of GDP in 2004 to 17 percent of GDP by 2023.

Noninterest expenditure is projected to increase from 25 percent of GDP in 2004 to a peak of $261 / 2$ percent of GDP by 2013 and then gradually fall to about 24 percent of GDP in 2023 when the large government investments to improve infrastructure decline.

The current account deficit (including grants) is projected to remain between 5 to 9 percent of GDP for the whole period. Excluding grants, it is projected to gradually improve from 22 percent of GDP in 2005 to about 15 percent of GDP in 2015 and 10 percent of GDP in 2023.

Gross borrowing is projected to be on average slightly over 2 percent of GDP (about one percent of GDP in 2008-15 with an increase to more than 2 percent of GDP by 2023) while official grants are projected to decrease gradually from about 12 percent of GDP over 2005-12 to 6 percent of GDP by 2023. Thus, on average, more than three-quarters of external financing will be in the form of grants, but the share of grants would decrease over time.

- Gross domestic savings did not pick up significantly since the decision point. However, given the importance of higher savings to reduce Rwanda's dependence on foreign capital flows to finance its investment needs, the framework now programs a gradual increase in savings, both in the government and the private sector, from 2.3 percent of GDP in 2004 to 9.0 percent of GDP in 2023. In particular, private savings are expected to benefit significantly in the next decade from reforms to stimulate the development of the financial sector, and create an enabling environment for the private sector.

26. Based on the revised macroeconomic framework, the staffs expect a substantial worsening in debt indicators over the long term compared with the decision point projections (Tables 17-19 and Figure 1). This holds true notwithstanding the ambitious assumptions regarding the degree of grant financing.

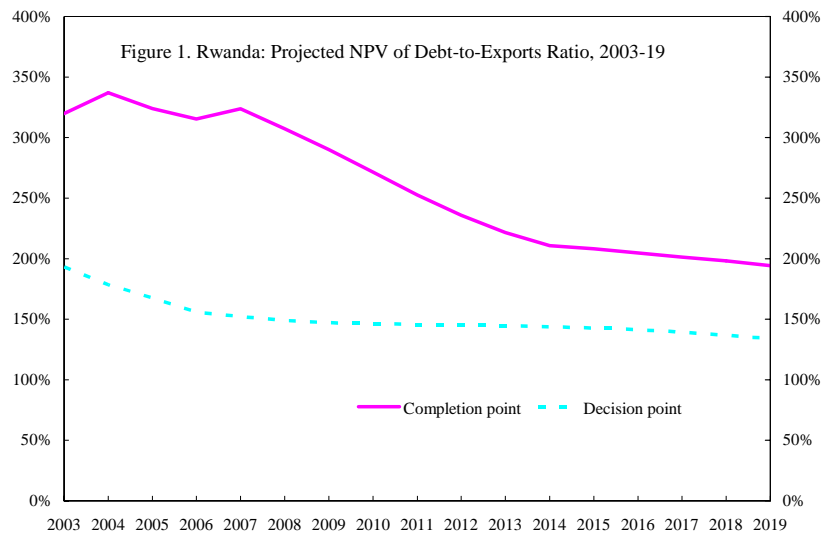


- The NPV of debt-to-exports ratio after enhanced HIPC assistance and additional bilateral debt relief is expected to remain above the HIPC threshold, throughout the entire projection horizon. From 320 percent at end2003, the ratio would peak at 337 percent in 2004 before beginning a slow, gradual decline to reach 191 percent in 2020 and 170 percent by 2023 . In contrast, at the time of the decision point, the ratio was expected to drop below the 150 percent HIPC threshold in 2008 and remain below that threshold throughout the projection period.

- Debt service as a share of exports is also expected to be substantially larger over the entire projection horizon. While this ratio would be expected to remain below 12 percent in any year, it would be, on average, almost twice as high as the decision point projections. Moreover, Rwanda's debt service payments will rise significantly after 2020, when IDA's assistance under the Enhanced HIPC Initiative assistance would end; as a result, the debt service-to-exports ratio would increase to an average of over 9 percent for the years 2021-23, and continue to rise thereafter.

\section{Sensitivity Analysis and Long-Term Debt Sustainability}

27. This section analyzes the impact of three alternative scenarios that could determine Rwanda's debt sustainability prospects: an external shock in the form of a deterioration in the terms of trade; a significant decline in grant financing; and a higher growth outlook, broadly in line with the authorities' baseline underlying their PRSP document (Table 20, and Figures 7 and 8). The first two scenarios illustrate the impact of potential risks to Rwanda's debt sustainability, while the last scenario suggests that higher growth, triggered by productivity gains, could result in an improvement in debt indicators, if accompanied by buoyant fiscal revenue. All scenarios clearly indicate that strengthening export performance is critical for achieving external debt sustainability. ${ }^{24}$

\section{Scenario 1: Terms of trade shock}

28. This scenario illustrates Rwanda's high vulnerability to changes in commodity prices and its dependence on imports for public investment by simulating a sharp drop of export prices and a simultaneous import price increase. Merchandise export prices in U.S. dollar terms would drop by 25 percent relative to the baseline in 2005 and thereafter increase at the same rates as in the baseline (by an average 2 percent per annum). The magnitude of the shock is comparable to recent history: in 1998, 2001, and 2002, Rwanda's export prices also dropped by more than 20 percent, mainly driven by a decline in coffee prices and, for 2001 and 2002, coltan.

\footnotetext{
${ }^{24}$ These results are corroborated by a DSA conducted under the new framework for low-income countries (Appendix II). According to this DSA, Rwanda's NPV of debt-to-exports ratio after enhanced HIPC Initiative assistance and additional bilateral debt relief at end-2003 stood at 286 percent. The ratio would fall below 200 percent only by 2012, and reach 142 percent by 2023 .
} 
The simulation further assumes that the sharp price decline would lead to a 2 percentage point reduction in export volume growth during 2005-07, before volume growth recovers to the rates assumed in the baseline. Moreover, there would be a simultaneous increase in import prices by 10 percent in 2005, which thereafter would grow at the baseline rates. The resulting balance-of-payments financing gap would be filled by a mix of budgetary loans and grants, similar to the one proposed under the baseline scenario.

29. Under such scenario, Rwanda's debt situation would substantially worsen. As a result of the lower export prices, total exports in U.S. dollar terms would fall, on average, by 15 percent per annum relative to the baseline scenario. Driven by the drop in exports and the additional new borrowing required to fill the gap, the NPV of debt-toexports ratio would peak at 383 percent in 2007, exceeding the baseline projections by 59 percentage points. Afterwards, the ratio would begin a slow decline, reaching 218 percent in 2023. At the same time, the debt service-to-exports ratio would worsen by about 1-2 percentage points compared with the baseline.

\section{Scenario 2: Reduction of external grants}

\section{This scenario illustrates the sensitivity of Rwanda's debt outlook to a} discontinuation of sizeable external support in the form of grants as assumed under the baseline. The "shock" is assumed to reduce the grant component in gross central government financing to 55 percent during the projection period from 83 percent in the baseline. ${ }^{25}$ The assumption of 55 percent is only slightly lower than the lowest share of grant financing observed in the interim period (60 percent in 2002). The outlook for the other macroeconomic aggregates is left unchanged.

\section{Such a grant “shock” would cause Rwanda's external debt situation to} remain unsustainable throughout the projection horizon. The NPV of debt-toexports ratio would rapidly increase to a peak of 391 percent in 2010 and then remain within a range of about 350-400 percent through 2023. In addition, servicing Rwanda's debt obligations would require an increasing share of the country's foreign exchange earnings, as evidenced by a worsening of the debt service-to-exports ratio, which would rise to 16 percent during 2021-23.

\section{Scenario 3: Higher GDP growth}

32. The third scenario analyzes the impact of higher GDP growth on Rwanda's debt sustainability. It assumes that the real GDP growth rate will exceed, on average, the baseline assumption by 1.5 percentage points over 2005-23. The higher growth path would be driven by stronger export performance, while additional import volume growth would be limited to 0.7 percentage points per year relative to the baseline. Spending as a share of GDP would be kept constant, while the broadening of the tax base and

\footnotetext{
${ }^{25}$ Off-budget grants that are channeled directly to subordinate government levels or NGO-financed projects are assumed to remain constant.
} 
efficiency gains would increase revenue by 1.5 percent per year beyond the nominal GDP growth. The higher revenue performance (as a share of GDP) would lower the external financing need and, assuming the same grant-loan mix as in the baseline scenario, a 17 percent share of the total savings would be used to reduce loan financing.

33. The lower borrowing requirement together with strengthened export performance would cause debt indicators to improve over the longer term. The NPV of debt-to-exports ratio, after Enhanced HIPC Initiative assistance and additional bilateral relief, would fall below the HIPC threshold of 150 percent in 2022 and reach 134 percent in 2023, while the debt service-to-exports ratio would slightly fall relative to the baseline scenario. This scenario thus shows that strong growth can reduce the country's debt burden, in particular if supported by a prudent fiscal strategy and a strong development of the export sector. However, this would require domestic revenue to grow faster than real GDP, and additional measures to strengthen revenue administration and broaden the tax base would likely be needed. It would also require export earnings, which today cover only about one-third of the import bill, to grow faster than imports and thus swift implementation of the export promotion strategy. Moreover, it is important to note that the scenario assumes higher growth would come from efficiency gains (or an increase in total factor productivity) rather than an increase in investment or labor supply, which, based on experience in other countries, is difficult to achieve.

\section{Summary}

34. The three scenarios suggest that a high and sustained level of grant financing, strong export growth, and a focus on further revenue mobilization are key to improving Rwanda's debt situation. This calls for a continued strong commitment to build on progress made since the decision point in strengthening the regulatory environment and infrastructure for private business in Rwanda, as well as implementing the export promotion strategy to lay the basis for strong, export-oriented growth. Further progress in revenue administration and, with a view to increasing the efficiency of spending, public expenditure management will also be needed. But even with strong future policy implementation, an improvement in the NPV of debt-toexports ratio will require significant external support in the form of grants.

\section{CONSIDERATION OF A TOPPING-UP OF ENHANCED HIPC INITIATIVE ASSISTANCE}

35. In the event of a deterioration of the debt indicators at the completion point beyond the HIPC thresholds, the enhanced HIPC Initiative framework allows for additional debt relief at the completion point ("topping-up") "if the deterioration in the member's debt sustainability is primarily attributable to a fundamental change in the country's economic circumstances due to exogenous factors."26 Additional

\footnotetext{
${ }^{26}$ See Box 1 ("Enhanced HIPC Initiative-Completion Point Considerations"). See also the discussion in "Draft Amendment to the PRGF-HIPC Trust Instrument".
} 
debt relief may then be provided to bring the NPV of debt-to-exports ratio down to 150 percent at the completion point.

36. With an NPV of debt-to-exports ratio reaching 320 percent at end-2003 after additional voluntary relief from bilateral creditors, Rwanda warrants consideration for additional HIPC debt relief. This section presents the case for topping-up by discussing the nature and the cause for the deterioration in the country's debt sustainability prospects. First, a decomposition of the change in the NPV of debtto-exports ratio is presented. However, as this decomposition captures only part of the economic developments since the decision point, developments in import prices, which do not directly affect the key HIPC debt indicators, but still influence Rwanda's ability to carry debt, are then considered.

\section{A. Decomposition of the Increase in the NPV of Debt-to-Exports Ratio}

\section{The NPV of debt-to-exports ratio at end-2003 more than doubled compared} with the HIPC threshold to 320 percent (assuming additional voluntary bilateral debt relief) due to several factors. Projections at the decision point anticipated an increase in the NPV of debt-to-exports ratio from 150 percent at end-1999 to 193 percent at end-2003, largely owing to the impact of new borrowing. However, projected growth in export earnings was expected to dampen the increase in the ratio. In fact, the actual ratio at end-2003 exceeded the anticipated ratio by 127 percentage points due to unanticipated developments.

38. A decomposition of the variation in the NPV of debt-to-exports ratio identifies four factors that had an important influence on the NPV of debt-toexports ratio (Table 3$):^{27}$

- new borrowing;

- $\quad$ changes in cross-currency exchange rates, especially between the euro and the U.S. dollar;

- $\quad$ export earnings; and

- a lower discount rate.

These factors are discussed in turn below.

\footnotetext{
${ }^{27}$ The net impact of other factors (including additional bilateral debt relief, and amortization and debt relief operations affecting the end-1999 debt stock) results in a minor increase of about 3 percentage point.
} 
Table 3. Rwanda: Breakdown of the Increase of NPV of Debt-to-Exports Ratio

From 150 Percent at End-1999 to 320 Percent at End-2003

(In percent, unless otherwise indicated)

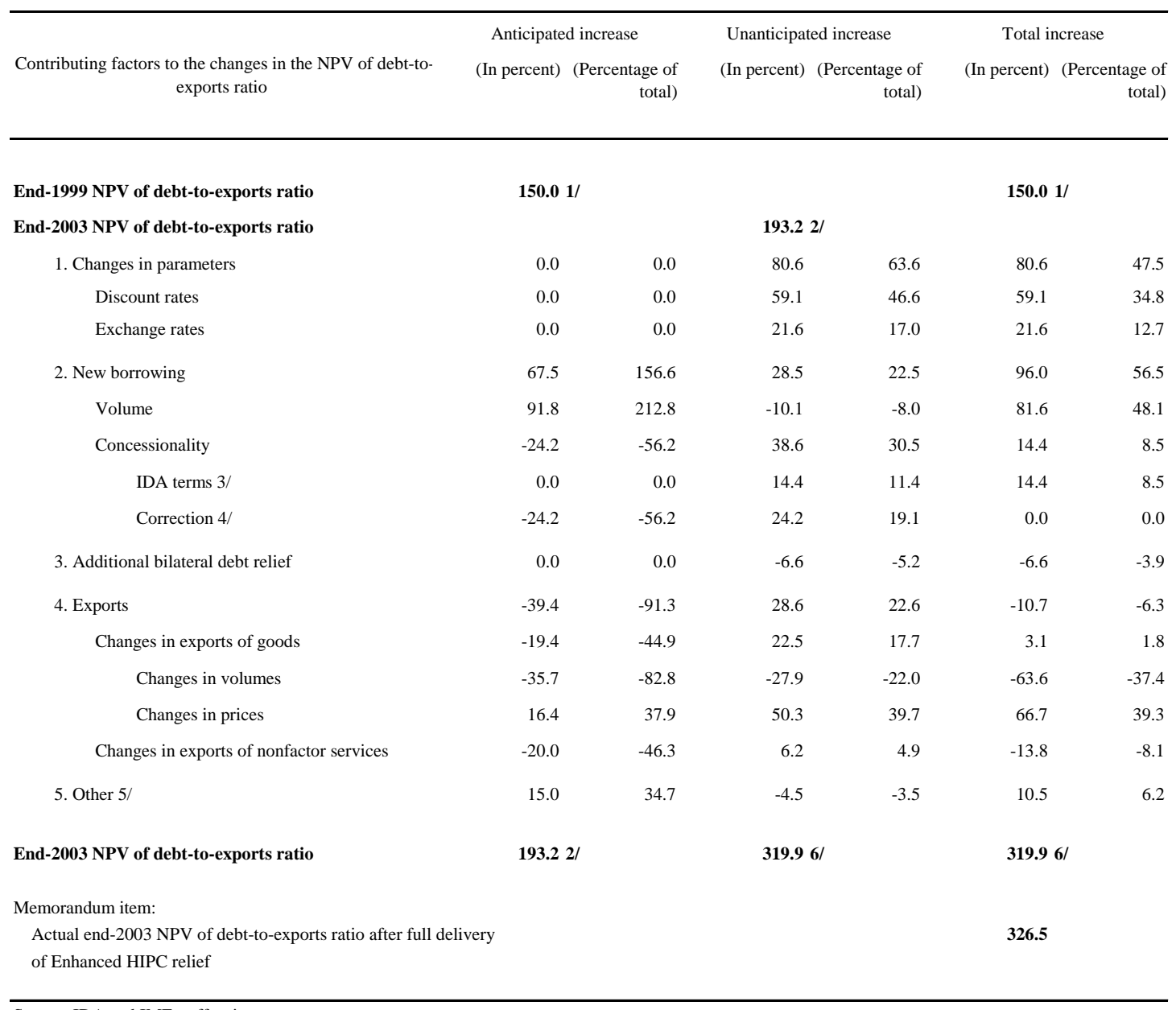

Source: IDA and IMF staff estimates.

1/ NPV of debt-to-exports ratio after full delivery of HIPC assistance as estimated at the decision point.

2/ NPV of debt-to-exports ratio after full delivery of HIPC assistance as projected at the decision point.

3/ At the decision point, new borrowing was assumed to be on standard IDA terms. However, new borrowing

was less concessional than expected.

4/ Refers mostly to the incorrect use, at the decision point, of the U.S. dollar discount rate for the estimate of the

NPV of new borrowing.

5/ Including amortization and debt relief operations affecting the end-1999 debt stock and differences

on the delivery of HIPC debt relief during the interim period compared to the decision point projections.

6/ Actual NPV of debt-to-exports ratio after full delivery of HIPC assistance and additional bilateral debt relief.

\section{New borrowing}

\section{At the decision point, it was projected that the volume of new borrowing} alone would cause an increase of 92 percentage points in the ratio. Although high, the decision point document justified this increase on the basis that national savings rates, in both the government and the private sector, would increase only gradually. Therefore, significant levels of new borrowing were needed to finance investments to stimulate growth and exports, given that the assumed share of grant financing was already above the historical trend. 


\section{In fact, Rwanda borrowed less than projected at the decision point.}

Disbursement volumes stayed well below the level anticipated at the decision point, leading to a lessening of the impact of new borrowing on the debt ratio by 10 percentage points. ${ }^{28}$ However, new borrowing was less concessional than expected (it should be noted in this context that it is difficult to project the concessionality of new borrowing, because it depends on the volume and mix of funding from donors that offer resources at differing interest rates and maturities). Also, projections at the decision point for new borrowing mistakenly used the relatively higher U.S. dollar discount rate instead of the SDR discount rate to calculate the NPV of SDR-denominated new borrowing. ${ }^{29}$ These factors led to a substantial underestimation of the decision point's projections of the future NPV of debt.

\section{Exchange rate changes}

41. Unanticipated changes in exchange rates, which are exogenous, led to a deterioration of 22 percentage points in Rwanda's NPV of debt-to-exports ratio (Table 13). The impact of such changes is significant as about three-quarters of Rwanda's nominal debt at end-2003 was denominated in SDRs and Euros, currencies that appreciated substantially against the U.S. dollar (Table 4). On the other hand, most of Rwanda's export receipts are denominated in U.S. dollars. Thus, the higher debt stock and debt service costs in U.S. dollar terms represent an additional burden, which constitutes a fundamental change in Rwanda's economic circumstances.

\footnotetext{
${ }^{28}$ One-third of the disbursements made in the interim period was on existing commitments as of end-1999.

${ }^{29}$ The SDR discount rate should have been used instead of the U.S. dollar discount rate, because most of the projected new borrowing was denominated in SDRs. The SDR discount rate at the time of the decision point was 5.59 percent, compared with a U.S. dollar discount rate of 7.04 percent. Consequently, the NPV of new borrowing for 2003 was substantially underestimated.
} 
Table 4. Rwanda: Structure of External Debt by Currency Denomination (In percent of total)

\begin{tabular}{|c|c|c|}
\hline & Nominal Value & Net Present Value \\
\hline & 2003 & 2003 \\
\hline Total & 100.0 & 100.0 \\
\hline Special Drawing Rights & 62.3 & 59.3 \\
\hline United States Dollar & 15.5 & 16.0 \\
\hline Euro & 12.2 & 13.2 \\
\hline Japanese Yen & 2.9 & 3.9 \\
\hline Kuwaiti Dinar & 2.0 & 1.7 \\
\hline Saudi Arabian Ryal & 1.9 & 1.9 \\
\hline Chinese Yuan & 1.9 & 2.7 \\
\hline Others & 1.2 & 1.3 \\
\hline
\end{tabular}

Sources: IDA and IMF staff estimates.

\section{Export performance}

42. The growth in export earnings lowered the NPV of debt-to-exports ratio by almost 11 percentage points between the decision and the completion points, but the contribution fell short of the level originally projected due entirely to a deterioration in export prices, which is an exogenous and fundamental factor. Export growth was much lower than projected at the decision point. This reflected volume growth above decision point projections, but much lower-than-expected export prices.

- The growth in merchandise export volumes improved the NPV of debt-toexports ratio by 64 percentage points. This performance was substantially stronger than anticipated in the decision point projections, which envisaged volume growth to average 13 percent per annum during 1999-2003, compared with an actual outturn of 18 percent (Figure 2). However, this strong overall performance masks an unexpected and temporary shift in the composition of Rwanda's

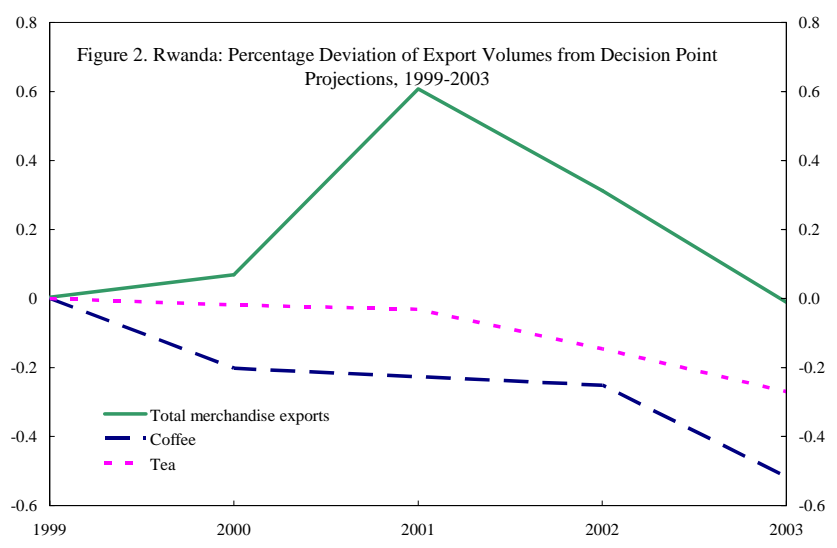
export base, as strong coltan exports benefited from the boom in the telecommunications industry in 2001 and 2002 and more than compensated for the poor performance of the traditional export sectors. In particular, coffee volumes remained substantially below 1999 levels in three out of the four consecutive years. In this context, and given that the coltan boom was a short- 
lived phenomenon, developments since the decision point clearly indicate the export sector's vulnerability to weak coffee and, to a lesser extent, tea harvests (Box 4).

- The fall in the prices for merchandise exports led to a 67 percentage point increase in the NPV of debt-to-exports ratio of which three-quarters were unanticipated at the decision point. This was mostly due to an unexpected continuation of the downward trend in coffee prices (Figure 3). At the trough of the coffee cycle in 2002, the unit price (US\$0.74) was about half of the price projected at the decision point. Together with declining prices for coltan

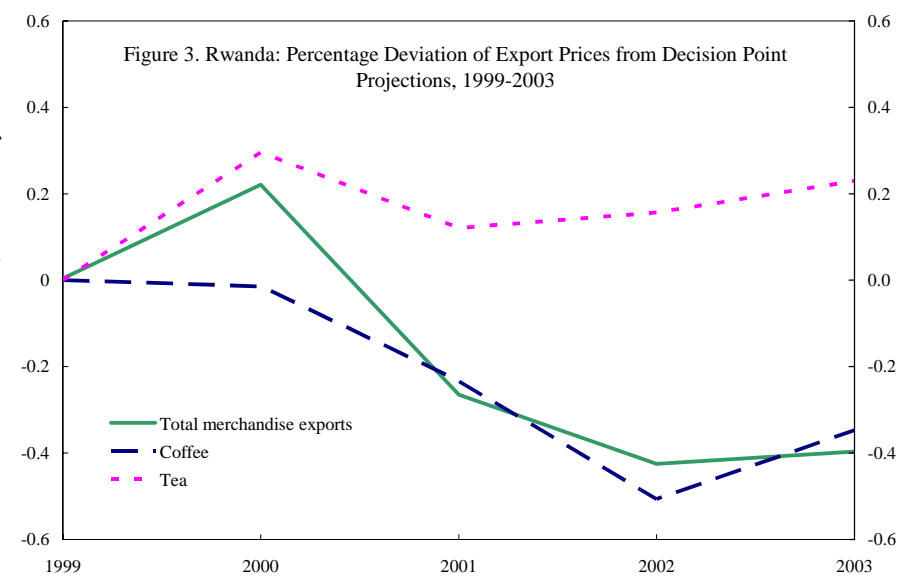
(after the peak in 2000) and nontraditional exports, this led to a 39 percent deviation from decision point projections in the (moving) price index for merchandise exports at end-2003, despite stronger-than-expected tea prices.

- Exports of nonfactor services improved the NPV of debt-to exports ratio by almost 14 percentage points, somewhat less than the improvement anticipated at the decision point. These developments reflected mainly the performance of the tourism sector, the expansion of which is likely to have been affected by instability in the Great Lakes region (see Box 4).

\section{Discount rate changes}

43. The fall in world interest rates, which is exogenous to Rwanda, played a substantial role in the deterioration of Rwanda's debt burden indicators (Table 13). The unexpected decline in discount rates between the decision and completion points contributed about one-third of the total change in the NPV of debt-to-exports ratio and almost half of the unanticipated change.

44. All else remaining equal, a decline in discount rates would be associated with a fundamental deterioration in Rwanda's economic circumstances through a reduction in its future export earnings. Theoretically, a lower interest rate on industrialized countries' benchmark bonds (used as the discount rate for HIPC calculations) reflects market expectations of a lower rate of inflation or a lower real 


\section{Box 4. Factors Underlying Rwanda's Export Performance}

While the authorities could have pursued more aggressive policies to support the export sector, a combination of factors appears to have been at play to explain the poor performance of some traditional export sectors relative to decision point projections. In particular, it was difficult at the decision point to anticipate the effects of climatic conditions and other shocks as well as the implications of structural problems - for instance, poor infrastructure; high transportation costs; electricity shortages; low capacity in production, processing and marketing; and insufficient access to capital (the last two factors partly reflect the destruction of human and physical capital during the genocide). Given the importance of raising export growth for external debt sustainability, strengthened efforts are now under way, including to diversify the export base. ${ }^{1 /}$ In particular, the results of an Integrated Trade Diagnostic Study, and a joint staff Financial Sector Assessment and Action Plan will inform the implementation of the government's export promotion strategy.

- In the coffee sector a large share of the grower population lacks critical skills and the size of production units is small while coffee trees have not been rejuvenated, resulting in a gradual decline in bean quality and quantity. ${ }^{2}$ In addition, production levels have been negatively affected by unfavorable rains, particularly in 2003 . The authorities have started to tackle these weaknesses by encouraging diversification toward higher-priced fully washed coffee.

- $\quad$ After recovering to pre-genocide levels by 1997, tea volumes remained at the same level through 2003, as productivity remained low and tea quality poor and volatile. The low productivity of the state-owned tea estates due to a lack of investment compared with that of a private factory indicate that privatization of the remaining tea factories should help redress this problem.

- While nontraditional exports (including hides and skins, pyrethrum, and cassiterite) increased, these products have not yet reached a critical mass to significantly diversify the export base as these industries are relatively new and dominated by small-scale and capitalconstrained firms.

Additional hotel capacity and improved infrastructure have helped boost tourism, but receipts fell short of expectations at the decision point, largely due to the poor integration of Rwanda's tourism sector with regional markets, as well as instability in the region. To address these problems the authorities are moving toward increased regional integration and are identifying actions to enhance the sector's performance under the export promotion strategy.

${ }^{1}$ On average, coffee and tea exports accounted for over half of total merchandise export earnings during 1999-2003.

${ }^{2}$ Coffee export volumes remain substantially below pre-genocide levels with annual exports averaging 17,300 tons over the period 1999-2003 compared with an average of 35,300 tons during 1984-89. See also Country Report No. 04/383, "Rwanda's Coffee Exports: Past Experience and Lessons for the Future." 
interest rate, which is normally associated with lower levels of economic activity. ${ }^{30}$ Both events can be expected to lower Rwanda's export earnings through lower future prices as well as volumes. Empirically, the effect of a change in discount rates cannot be easily isolated from the many other factors that affect a country's export outlook, including supply and demand shifts in world commodity markets. Nevertheless, despite the likely presence of other factors, a note to the IMF Board on the informational content of the CIRR discount rate found a statistically significant impact of interest rate changes on the export outlook of HIPC countries. In particular, for Rwanda, a 100 basis point reduction in industrial country interest rates in the past was associated with a 6 percent fall in the country's export prices over a subsequent five-year horizon. ${ }^{31,32}$

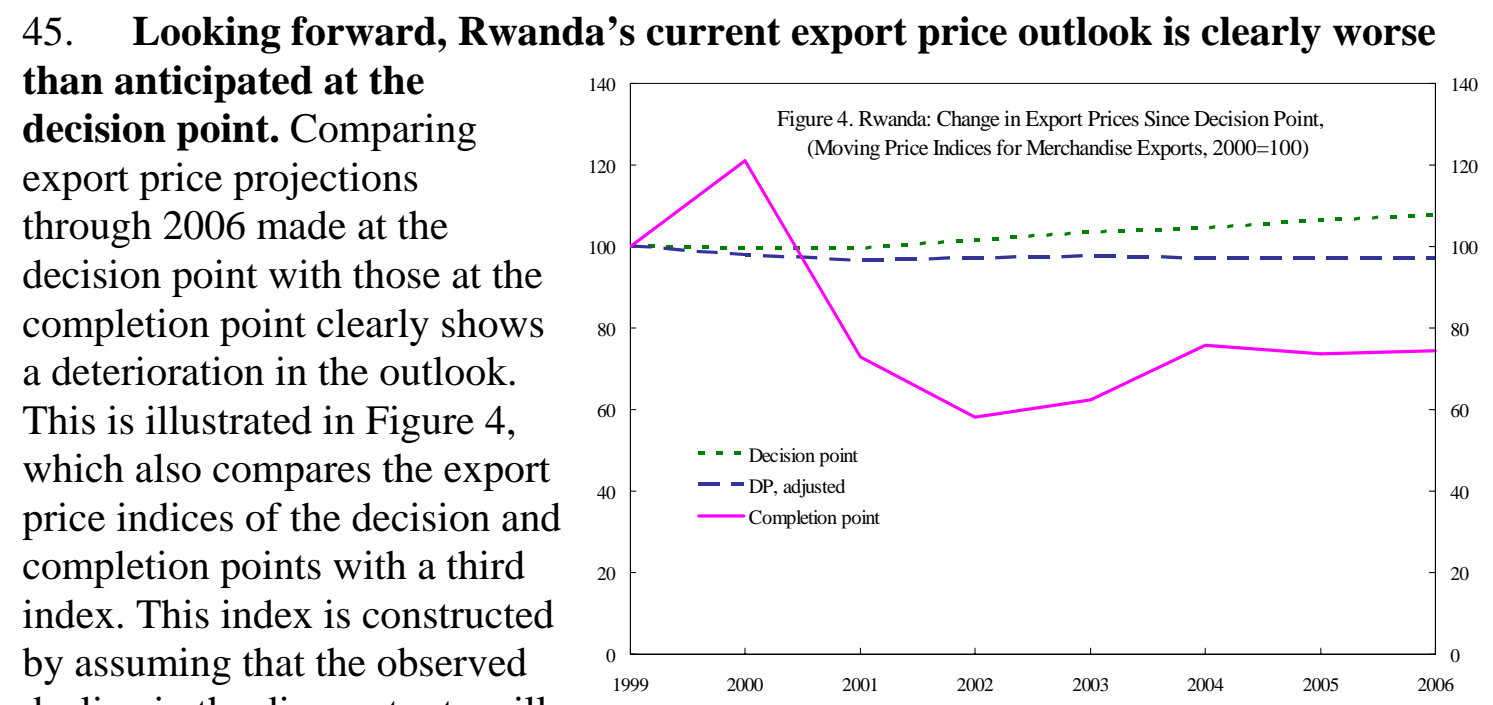
decline in the discount rate will

\footnotetext{
${ }^{30}$ Recent analysis suggests that these two factors largely explain the fluctuations in long-term interest rates and, for the case of the US, their contribution is roughly the same (Claudio Raddatz: "Changes in Interest Rates and the Debt Burden of HIPCs," World Bank mimeo).

${ }^{31}$ Such a correlation, however, is not reproduced in other specifications using export values instead of prices as the dependent variable, which could be due to the fact that the data included the genocide period during which export volumes dropped substantially.

32 The effect of a discount rate decline on a country's economic circumstances could also be gauged by analyzing changes in the NPV of debt-to-NPV of exports ratio. The discount rate change would affect this ratio through changes in the present value in both the numerator and denominator, allowing the discounted value of future export earnings to be taken into account. The NPV of debt over NPV of exports ratio at end2003 more than doubles from 11 percent estimated at the decision point to 25 percent estimated at the completion point, reflecting the impact of the total change in projected export values (which, in principle, captures the indirect impact of lower discount rates as well as other factors). (For this analysis, the data series for the decision point were extended using assumptions comparable to completion point projections from 2007 onward, since the decision point database includes prices and volume projections only through 2006.)
} 
cause an equivalent drop in the rate of inflation of Rwanda's export prices. ${ }^{33}$ The comparison shows that the projected level of the export price index at the completion point is substantially lower than that of the constructed index, indicating that the outlook for Rwanda's export prices is even weaker than that implied by the assumption of a oneto-one relationship between the discount rates and Rwanda's export prices. Moreover, on the basis of current price forecasts for tea and

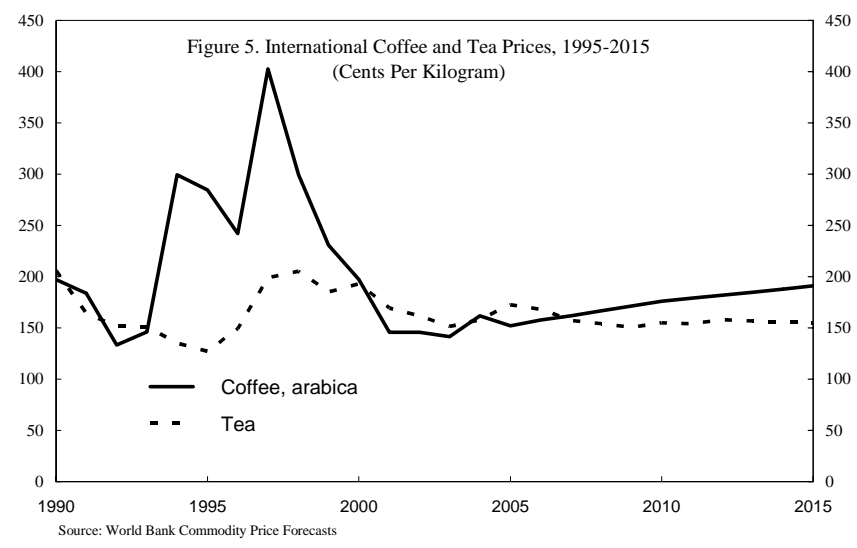
coffee by the World Bank, it appears that the large decline in export prices will last for several years with prices returning to decision point levels only after 2015 (Figure 5). For coffee, this could reflect the entry of new producers in the market since the decision point. $^{34}$

\section{B. Other Considerations Affecting Rwanda's Economic Circumstances}

46. One other factor that is likely to have an impact on Rwanda's debt-servicing capacity going forward, is the unanticipated sharp increase in imported energy prices between the decision and completion points. At the decision point, import prices were expected to increase by 12 percent between 1999 and 2006. By contrast, the completion point projections envisage a much stronger increase of 29 percent over the same period, with a particularly steep rise in 2004 due to higher energy prices. These changes affecting Rwanda's repayment capacity do not appear in the decomposition table, but are as material and relevant as a decline in export prices. Moreover, forecasts suggest that energy prices are also expected to remain at relatively high levels (in comparison to forecasts at the decision point in 2000). This implies that, other things equal, a higher share of export receipts would be required for the financing of imports rather than the repayment of debt and suggests that the added burden on servicing debt can be expected to remain over the medium to long term.

\section{Staff Assessment}

\section{Reviewing all evidence available and after full examination of Rwanda's} economic situation, the staffs are of the view that the substantial deterioration in

\footnotetext{
${ }^{33}$ The decline in the discount rate is assumed entirely to reflect lower global inflation expectations.

${ }^{34}$ According to the International Coffee Organization, coffee demand increased by 1.5 percent in the last couple of years while production rose at an average rate of 3.6 percent, as a result of new plantations in Brazil and Colombia and the rapid expansion of production in Vietnam (although the latter involves Robusta, while Rwanda produces Arabica).
} 
Rwanda's NPV of debt-to-exports ratio between the decision and completion points is primarily attributable to fundamental changes in the country's economic circumstances due to exogenous factors. Lower export prices, changes in crosscurrency exchange rates, and a lower-than-expected concessionality of new borrowing were all unambiguously exogenous and outside the control of the authorities. Moreover, staffs have presented additional analysis establishing the lower discount rates as an exogenous and fundamental factor causing a deterioration in Rwanda's NPV of debt-toexports ratio. All these factors account for more than 50 percent of both the unanticipated and the total increase of the ratio and thus provide sufficient justification for topping-up of debt relief at the completion point. The contribution of high volumes of new borrowing cannot be considered exogenous, but it is critical to note that the volume through end-2003 in fact remained below the levels anticipated at the time of the decision point and one-third was related to existing projects. In addition, the unanticipated worsening of import prices compared with decision point projections can be expected to have a lasting negative impact on Rwanda's terms of trade and, consequently, its capacity to repay its debt. Taken together, and in line with the topping-up methodology approved by the Boards of IDA and the IMF, the staffs consider that Rwanda's case meets the requirements for topping-up at the completion point.

48. Staffs therefore recommend that additional HIPC Initiative relief be granted to bring Rwanda's NPV of debt-to-exports ratio from 320 percent at end-2003 (after additional voluntary bilateral debt relief) down to the HIPC Initiative threshold of 150 percent. This recommendation is further supported by the observation that the authorities (i) remain committed to reforms exemplified by continued improvements in the implementation of policies; (ii) have borrowed prudently despite Rwanda being adversely affected by external shocks, including a deterioration in its terms of trade; and (iii) are taking measures to improve export performance, in particular, by initiating the implementation of their export promotion strategy. On the basis of the updated DSA, a topping-up of US\$243.1 million of HIPC Initiative assistance in NPV terms at the completion point would be needed to achieve the required reduction.

49. With topping-up, Rwanda's external debt situation would improve considerably over the projection period, freeing up resources to be used for additional PRSP-related spending. Under the baseline scenario for new lending from IDA and other concessional sources, the NPV of debt-to-exports ratio is projected to rise from 150 percent in 2003 to 200 percent in 2007; the ratio is then projected to fall to 150 percent in 2014 and remain around this level for the following 10 years. At the same time, the debt service-to-exports ratio is estimated to fall to 4 percent by 2011 and stay between 4 and 5 percent for the rest of the projection period. ${ }^{35}$

\footnotetext{
35 These projections assume that grants will comprise 83 percent of financing.
} 


\section{Conclusions}

50. The staffs of the IMF and IDA are of the view that Rwanda's performance with respect to the conditions for reaching the completion point under the Enhanced HIPC Initiative has been satisfactory. The full PRSP was prepared and implemented satisfactorily, the PRGF-supported program has had a track record of more than six months, and key structural reforms and social measures have been implemented. Given the overall strong progress in structural reforms and the policy commitments made with regard to the privatization of tea estates, the staffs recommend that a waiver of the completion point trigger on the tea sector be granted.

\section{In light of the above, the staffs of the IMF and IDA recommend that the} Executive Directors determine that Rwanda has reached the completion point under the Enhanced HIPC Initiative framework and that additional assistance beyond that already committed at the decision point in the amount of US\$243.1 million in NPV terms be granted to lower Rwanda's NPV of debt-toexports ratio at end-2003 to 150 percent. The additional assistance of the IMF would be disbursed when other creditors provide satisfactory assurances of their participation in this exceptional effort. Once satisfactory assurances have been received, IMF staff will return to the IMF Board with a proposed decision approving the disbursement of the IMF's share of the additional relief.

\section{ISSUES FOR DISCUSSION}

Staffs seek guidance from Directors on the following points:

- $\quad$ Do Directors agree that Rwanda has met the conditions for reaching the completion point at this time?

- $\quad$ Do Directors agree that Rwanda's poverty reduction strategy and expendituretracking system provide a satisfactory basis for ensuring that enhanced HIPC Initiative assistance and other resources will continue to promote poverty reduction?

- $\quad$ Do Directors agree that satisfactory assurances have been given by Rwanda's other creditors to commit enhanced HIPC Initiative resources to Rwanda, as approved at the decision point, on an irrevocable basis?

- Do Directors agree that the deterioration in Rwanda's debt sustainability is primarily attributable to a fundamental change in its economic circumstances due to exogenous factors?

- If so, do Directors agree that exceptional additional HIPC Initiative assistance be granted to lower Rwanda's NPV of debt-to-exports ratio at end-2003 to 150 percent? 
- If so, do Directors agree that this additional assistance would be granted when the Boards decide that other creditors provide sufficient assurances to participate in this exceptional effort? 
Figure 6. Rwanda: Composition of External Debt 1/ (In millions of U.S. dollars)

\section{end-1999 2/}

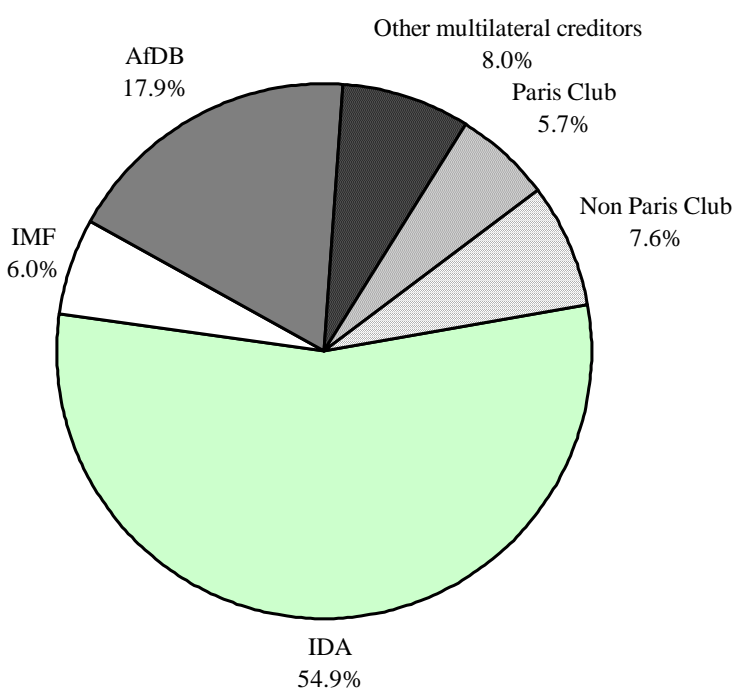

end-2003 3/

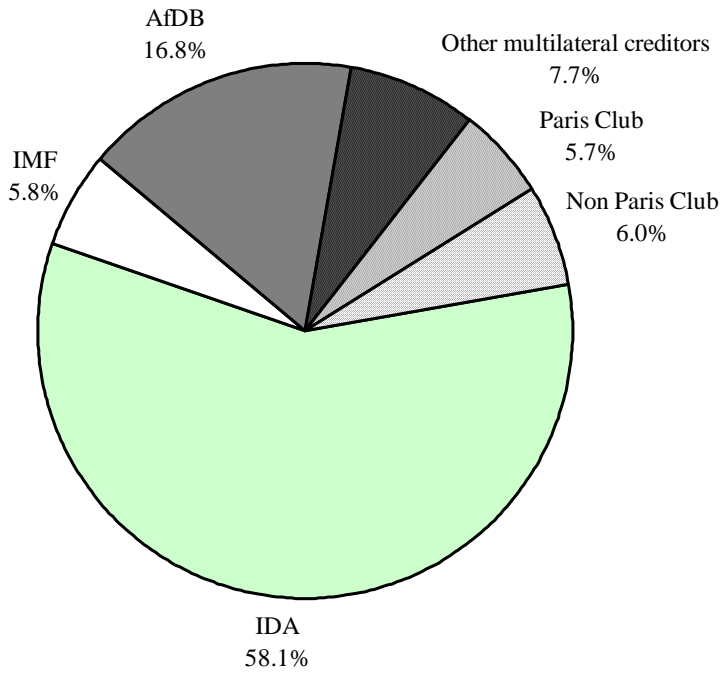

Source: Rwandese authorities; and IDA and IMF staff estimates and projections.

1/ NPV of debt after the application of traditional debt relief mechanisms.

2/ At end-1999 discount and exchange rates.

3/ At end-2003 discount and exchange rates. 
Figure 7. Rwanda: External Debt and Debt Service Indicators for Medium-and Long-Term Public Sector Debt, 2003-23

(In percent)

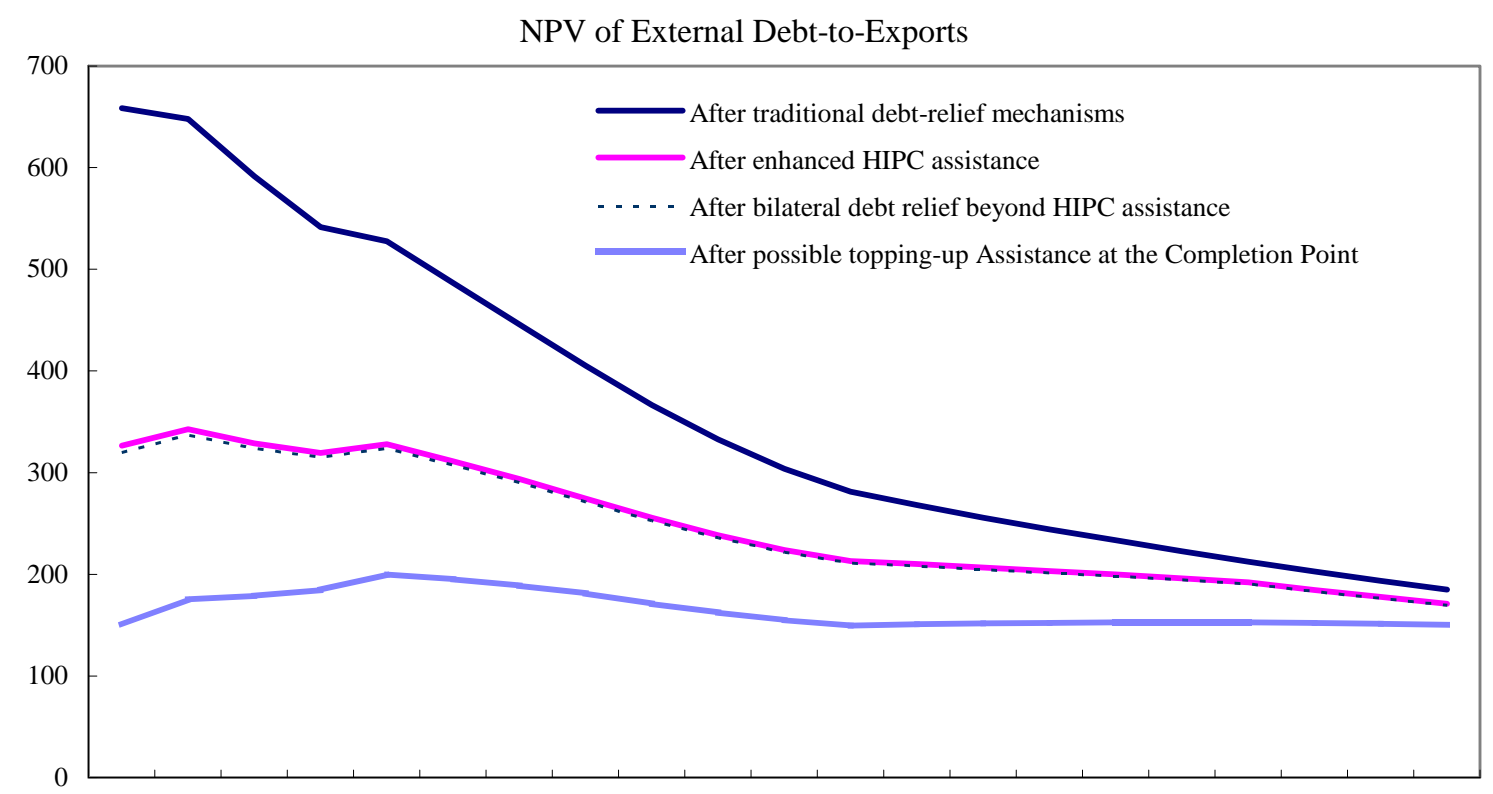

$2003200420052006200720082009201020112012 \quad 2013201420152016201720182019202020212022 \quad 2023$

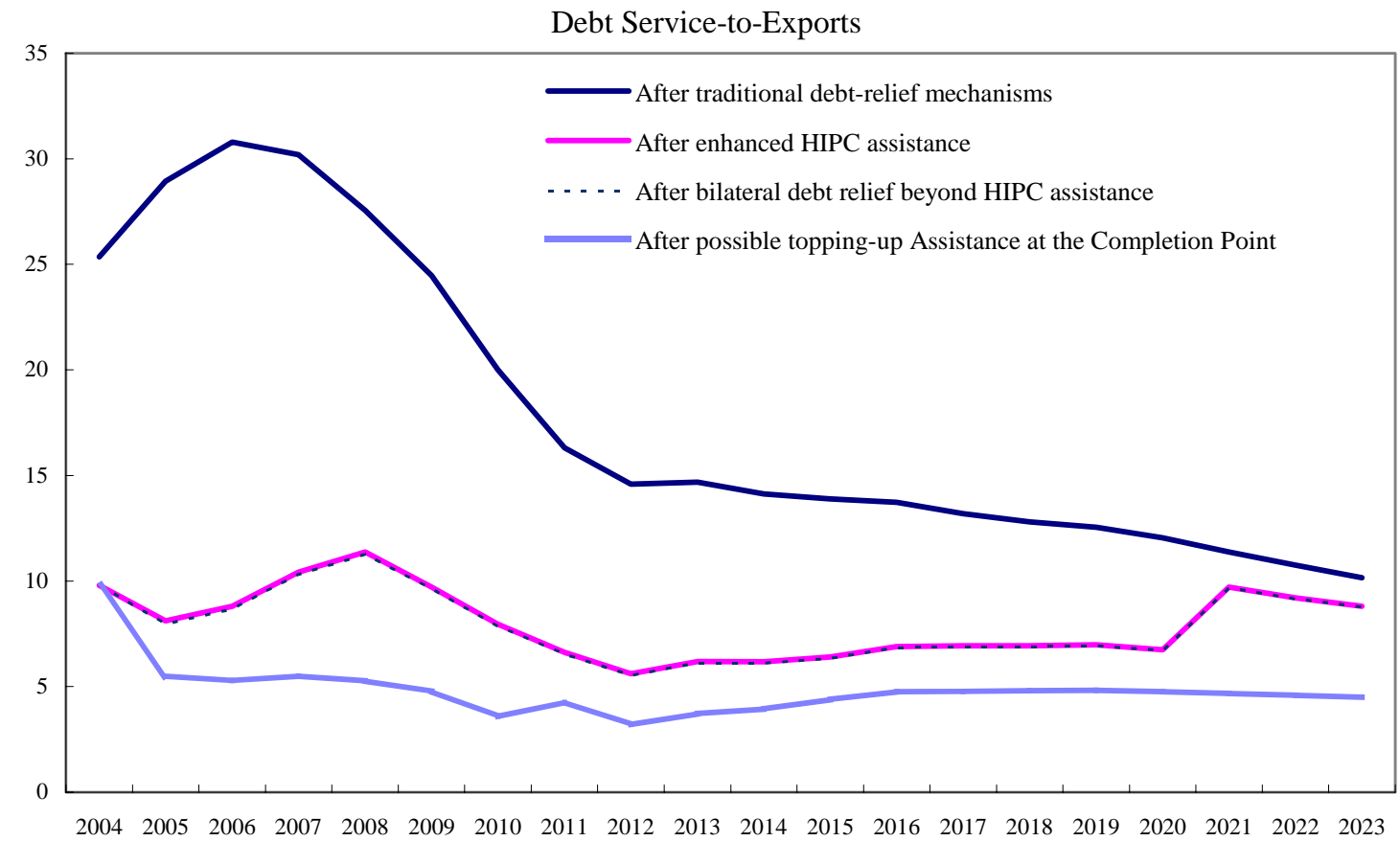

Sources: Rwandese authorities; and IDA and IMF staff estimates and projections. 
Figure 8. Rwanda: Sensitivity Analysis, 2003-23

(In percent)

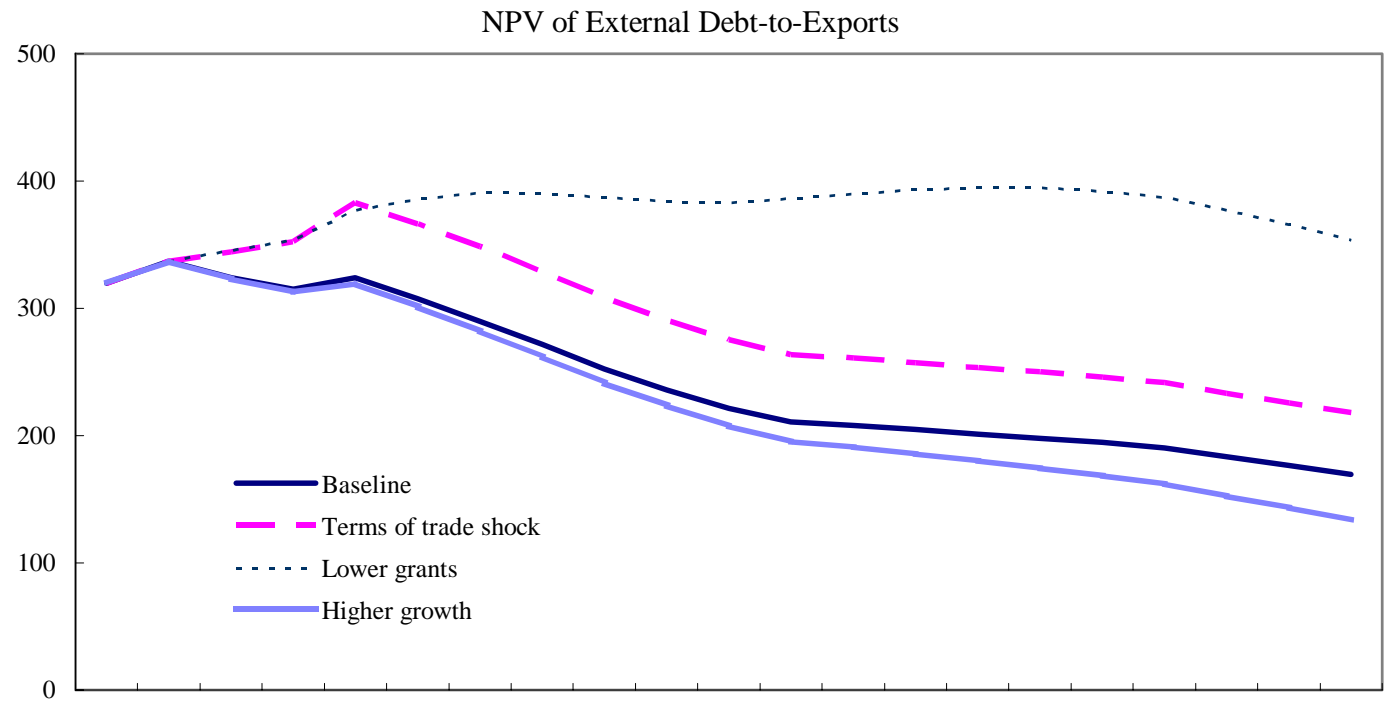

$20032004200520062007200820092010201120122013 \quad 201420152016201720182019202020212022 \quad 2023$

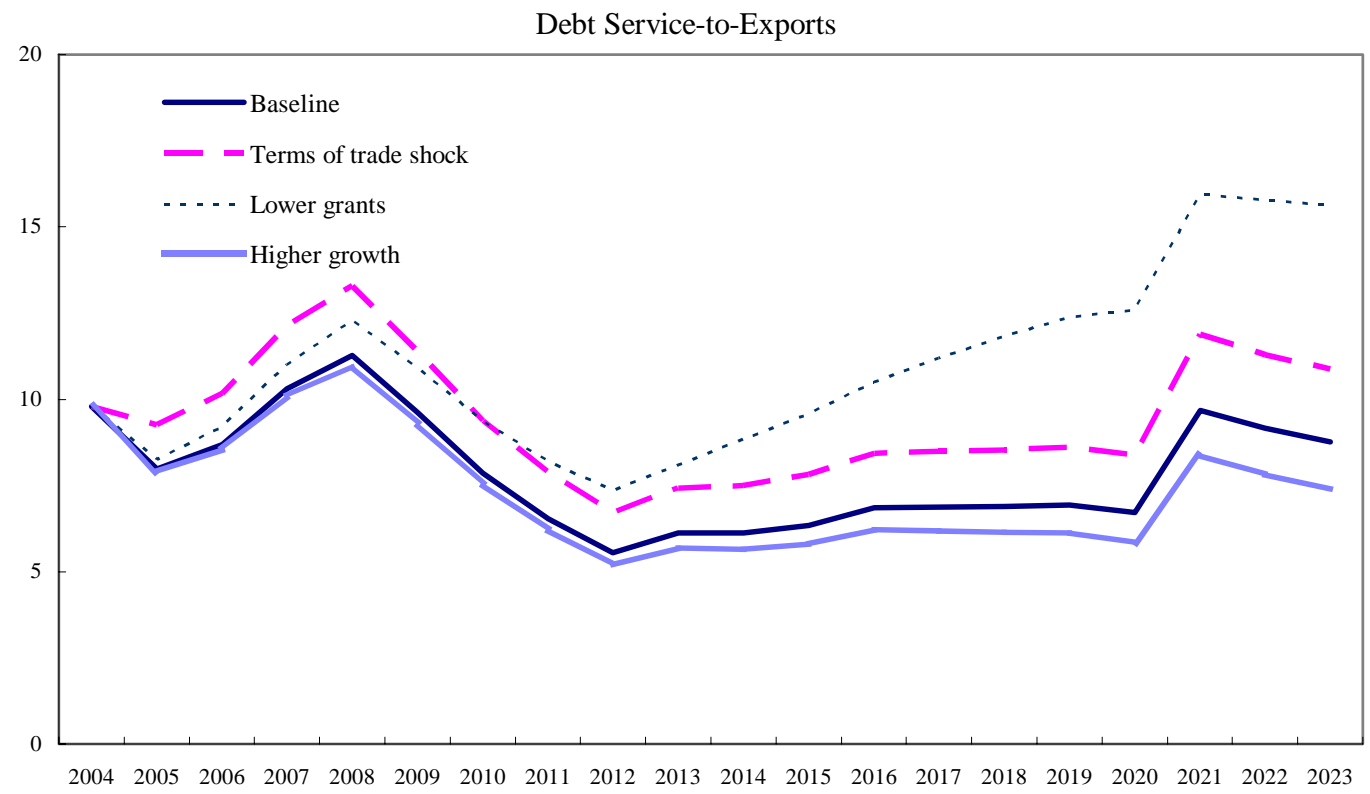

Sources: Rwandese authorities; and IDA and IMF staff estimates and projections. 
Table 5. Rwanda: Selected Social and Demographic Indicators

\begin{tabular}{|c|c|c|c|c|c|}
\hline & \multicolumn{3}{|c|}{ Latest Single Year } & \multicolumn{2}{|c|}{ Same Region/Income Group } \\
\hline & $1970-75$ & $1980-85$ & $1995-2001$ & & \\
\hline \multicolumn{6}{|l|}{ Population } \\
\hline Total population, mid year (millions) & 4.4 & 6.1 & 7.9 & 673.9 & 2505.9 \\
\hline Growth rate (percentage; annual average for pes & 3.3 & 3.5 & 2.9 & 2.5 & 1.9 \\
\hline Urban population (percentage of population) & 4.0 & 5.0 & 15.2 & 32.3 & 30.8 \\
\hline Total fertility rate (births per woman) & 8.4 & 7.7 & 5.9 & 5.1 & 3.5 \\
\hline \multicolumn{6}{|l|}{ Income } \\
\hline GNI per capita (US\$) & 100.0 & 270.0 & 240.0 & 460.0 & 430.0 \\
\hline Consumer price index $(1995=100)$ & 13.0 & 30.6 & 133.9 & $\ldots$ & $\ldots$ \\
\hline Food price index $(1995=100)$ & $\ldots$ & 39.5 & 162.2 & $\ldots$ & ... \\
\hline \multicolumn{6}{|l|}{ Income/consumption distribution } \\
\hline \multicolumn{6}{|l|}{ Share of income or consumption } \\
\hline Gini index & $\ldots$ & 28.9 & $\ldots$ & $\ldots$ & ... \\
\hline Lowest quintile (percentage of income or consum] & $\ldots$ & 9.7 & $\ldots$ & $\ldots$ & ... \\
\hline Highest quintile (percentae of income or consump & $\ldots$ & 39.1 & $\ldots$ & $\ldots$ & ... \\
\hline \multicolumn{6}{|l|}{ Social indicators } \\
\hline \multicolumn{6}{|l|}{ Public expenditure } \\
\hline Health (percentage of GDP) & $\ldots$ & $\ldots$ & 5.5 & 2.5 & 1.1 \\
\hline Education (percentage of GDP) & $\ldots$ & $\ldots$ & $\ldots$ & 3.4 & 2.8 \\
\hline \multicolumn{6}{|l|}{$\begin{array}{l}\text { Net primary school enrollment rate } \\
\text { (percentage of age group) }\end{array}$} \\
\hline Total & $\ldots$ & 59.8 & 96.1 & $\ldots$ & ... \\
\hline Male & $\ldots$ & 61.1 & 96.8 & $\ldots$ & ... \\
\hline Female & $\ldots$ & 58.5 & 95.4 & 52.0 & ... \\
\hline \multicolumn{6}{|l|}{$\begin{array}{l}\text { Access to an improved water source } \\
\text { (percentage of population) }\end{array}$} \\
\hline Total & $\ldots$ & $\ldots$ & $\ldots$ & 58.1 & 76.1 \\
\hline Urban & $\ldots$ & $\ldots$ & $\ldots$ & 82.7 & 90.2 \\
\hline Rural & $\ldots$ & $\ldots$ & $\ldots$ & 46.4 & 70.1 \\
\hline \multicolumn{6}{|l|}{$\begin{array}{l}\text { Immunization rate } \\
\text { (percentage under } 12 \text { months) }\end{array}$} \\
\hline Measles & $\ldots$ & 52.0 & 69.0 & 57.8 & 59.8 \\
\hline DPT & $\ldots$ & 50.0 & 77.0 & 52.9 & 61.5 \\
\hline Child malnutrition (percentage under 5 years) & $\ldots$ & $\ldots$ & 24.3 & $\ldots$ & ... \\
\hline \multicolumn{6}{|l|}{$\begin{array}{l}\text { Life expectancy at birth } \\
\text { (years) }\end{array}$} \\
\hline Total & 44.8 & 47.5 & 39.9 & 46.2 & 58.9 \\
\hline Male & 43.2 & 45.8 & 39.5 & 45.4 & 57.9 \\
\hline Female & 46.4 & 49.3 & 40.4 & 47.0 & 60.0 \\
\hline \multicolumn{6}{|l|}{ Mortality } \\
\hline Infant (per 1,000 live births) & 124.0 & 130.0 & 118.0 & 105.4 & 80.4 \\
\hline Under 5 (per 1,000 live births) & 209.0 & 219.0 & 203.0 & 170.6 & 120.6 \\
\hline \multicolumn{6}{|l|}{ Adult (15-59) } \\
\hline Male (per 1,000 population) & 502.2 & 502.6 & 667.0 & 519.9 & 311.9 \\
\hline Female (per 1,000 population) & 402.7 & 408.6 & 599.0 & 461.3 & 255.7 \\
\hline Births attended by skilled health staff (percentage) & $\ldots$ & $\ldots$ & 31.3 & $\ldots$ & $\ldots$ \\
\hline
\end{tabular}

Source: World Bank, World Development Indicators. 
Table 6. Rwanda: Selected Economic and Financial Indicators, 2000-08

\begin{tabular}{|c|c|c|c|c|c|c|c|c|c|}
\hline & 2000 & 2001 & 2002 & 2003 & 2004 & 2005 & 2006 & 2007 & 2008 \\
\hline & & & & & & \multicolumn{4}{|c|}{ Projections } \\
\hline & \multicolumn{9}{|c|}{ (Annual percentage change, unless otherwise indicated) } \\
\hline \multicolumn{10}{|l|}{ National income and prices } \\
\hline GDP at constant prices & 6.0 & 6.7 & 9.4 & 0.9 & 4.0 & 4.0 & 4.3 & 4.5 & 4.7 \\
\hline GDP deflator & 3.3 & 0.2 & 0.0 & 8.7 & 12.0 & 6.4 & 4.0 & 4.0 & 4.0 \\
\hline \multicolumn{10}{|l|}{ Consumer price index } \\
\hline Annual average & 3.9 & 3.4 & 2.0 & 7.4 & 12.0 & 7.0 & 4.0 & 4.0 & 4.0 \\
\hline End of period & 5.8 & -0.2 & 6.2 & 7.7 & 10.2 & 6.0 & 4.0 & 4.0 & 4.0 \\
\hline \multicolumn{10}{|l|}{ External sector } \\
\hline Exports, f.o.b. & 44.7 & 4.2 & -28.1 & -6.3 & 54.3 & -8.3 & 7.1 & 7.1 & 10.2 \\
\hline Imports, f.o.b & -3.6 & -0.8 & -1.3 & 4.0 & 12.5 & 28.1 & 5.7 & 4.4 & 5.2 \\
\hline Export volume & 19.7 & 73.2 & -10.0 & -12.5 & 26.8 & -5.6 & 5.8 & 6.2 & 8.3 \\
\hline Import volume & -14.6 & 2.3 & -6.3 & 1.1 & 4.6 & 25.9 & 6.0 & 4.3 & 4.6 \\
\hline Terms of trade (deterioration -) & 7.1 & -37.9 & -24.0 & 4.1 & 13.2 & -4.5 & 1.5 & 0.7 & 1.1 \\
\hline Nominal effective exchange rate (depreciation -) & -13.0 & -1.8 & -15.6 & -23.0 & -1.4 & $\ldots$ & $\ldots$ & $\ldots$ & $\ldots$ \\
\hline Real effective exchange rate (depreciation -) & -10.5 & -3.5 & -12.3 & -19.1 & 7.1 & $\ldots$ & $\ldots$ & $\ldots$ & $\ldots$ \\
\hline Gross official reserves (in months of imports) & 5.4 & 6.0 & 6.3 & 5.0 & 5.8 & 4.8 & 4.8 & 4.8 & 4.4 \\
\hline \multicolumn{10}{|l|}{ Government finances } \\
\hline Total revenue & 35.9 & 8.3 & 7.9 & 22.3 & 39.7 & 10.2 & 10.1 & 5.5 & 15.8 \\
\hline Total expenditure and net lending & 4.2 & 20.0 & 10.5 & 23.7 & 27.5 & 12.9 & 12.5 & 7.1 & 8.1 \\
\hline Of which: Current expenditure & 3.7 & 20.4 & 14.0 & 31.4 & 4.7 & 19.0 & 7.0 & 7.3 & 8.9 \\
\hline Capital expenditure & 2.9 & 19.1 & -18.6 & 25.5 & 75.6 & 15.7 & 23.8 & 6.9 & 6.9 \\
\hline \multicolumn{10}{|l|}{ Money and credit } \\
\hline Domestic credit & 0.7 & 0.3 & -4.0 & 19.7 & -22.6 & 14.9 & $\ldots$ & $\ldots$ & $\ldots$ \\
\hline Credit to the government (net) & -9.6 & -5.1 & -12.4 & 10.7 & -28.8 & 8.2 & $\ldots$ & $\ldots$ & $\ldots$ \\
\hline Credit to the economy & 10.3 & 5.4 & 8.5 & 9.0 & 6.1 & 6.7 & $\ldots$ & $\ldots$ & $\ldots$ \\
\hline Net domestic assets & -6.8 & -2.6 & -6.1 & 14.8 & -31.9 & 23.7 & $\ldots$ & $\ldots$ & $\ldots$ \\
\hline Money and quasi money & 14.3 & 9.2 & 11.4 & 15.2 & 12.6 & 5.4 & $\ldots$ & $\ldots$ & $\ldots$ \\
\hline Interest rate (money market, in percent; end of period) & 11.6 & 10.2 & 9.0 & 9.4 & 9.6 & $\ldots$ & $\ldots$ & $\ldots$ & $\ldots$ \\
\hline & \multicolumn{9}{|c|}{ (In percent of GDP, unless otherwise indicated) } \\
\hline Government finances & & & & & & & & & \\
\hline Total revenue & 19.4 & 19.6 & 19.4 & 21.6 & 25.9 & 25.8 & 26.2 & 25.4 & 27.1 \\
\hline Total expenditure and net lending & 18.7 & 21.0 & 21.2 & 23.9 & 26.1 & 26.7 & 27.7 & 27.3 & 27.1 \\
\hline Of which: Current expenditure & 12.6 & 14.2 & 14.8 & 17.8 & 16.0 & 17.2 & 17.0 & 16.7 & 16.7 \\
\hline Capital expenditure & 6.0 & 6.6 & 4.9 & 5.6 & 8.5 & 8.9 & 10.2 & 10.0 & 9.8 \\
\hline Domestic fiscal balance (excluding demobilization) & -2.3 & -2.2 & -3.8 & -4.7 & -5.3 & -4.5 & -5.9 & -5.9 & -5.6 \\
\hline Overall balance (before grants) & -8.9 & -9.5 & -8.9 & -10.3 & -12.2 & -12.7 & -13.6 & -13.0 & -12.6 \\
\hline Gross investment & 17.5 & 18.4 & 16.9 & 18.4 & 20.5 & 21.0 & 22.3 & 22.3 & 22.2 \\
\hline Gross domestic savings & 1.3 & 2.6 & 0.0 & -0.8 & 2.3 & -1.3 & 1.4 & 2.2 & 2.9 \\
\hline \multicolumn{10}{|l|}{ External current account balance } \\
\hline Excluding grants for budgetary assistance & -16.5 & -15.9 & -16.6 & -19.2 & -18.1 & -21.9 & -20.4 & -19.4 & -18.5 \\
\hline Including grants for budgetary assistance & -5.0 & -5.9 & -6.7 & -7.8 & -3.0 & -9.0 & -7.0 & -7.2 & -5.8 \\
\hline External public debt (end of period) & 75.0 & 79.3 & 80.6 & 88.4 & 88.8 & 73.1 & 70.3 & 68.0 & 63.6 \\
\hline \multicolumn{10}{|l|}{ Debt service after HIPC Initiative (in percent of } \\
\hline Exports of goods and services & $\ldots$ & 14.1 & 12.0 & 11.1 & 9.7 & 7.9 & 8.6 & 10.2 & 11.1 \\
\hline Government revenue & $\cdots$ & 11.4 & 7.5 & 6.8 & 7.2 & 5.1 & 5.6 & 6.7 & 6.2 \\
\hline & \multicolumn{9}{|c|}{ (In millions of U.S. dollars) } \\
\hline GDP at current market prices & 1,794 & 1,704 & 1,732 & 1,684 & 1,835 & 2,057 & 2,209 & 2,353 & 2,512 \\
\hline \multicolumn{10}{|l|}{ Government payments arrears (reduction -) } \\
\hline Domestic & -1.9 & -15.0 & -3.9 & -1.0 & -17.1 & -6.5 & -7.0 & -7.0 & 0.0 \\
\hline External & 7.1 & -37.8 & 4.6 & -22.6 & 1.3 & -6.6 & 0.0 & 0.0 & 0.0 \\
\hline Overall balance of payments & -3.8 & 22.9 & 18.2 & -33.6 & 87.7 & -58.9 & 16.8 & 13.5 & -3.1 \\
\hline
\end{tabular}

Sources: Rwandese authorities; and IMF staff estimates and projections. 
Table 7. Rwanda: Observance of Quantitative and Structural Performance Criteria and Benchmarks under the PRGF Arrangements 2001-04 1/

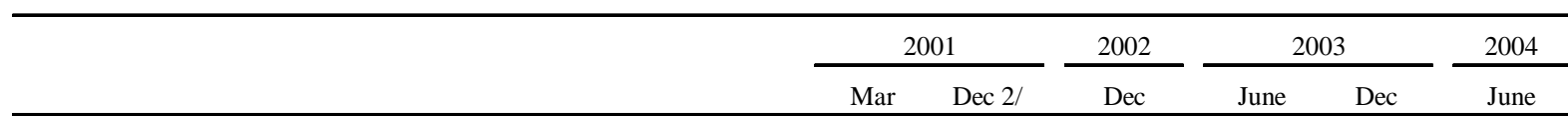

\section{Quantitative Performance Criteria}

Net foreign assets of the NBR

Net domestic assets of the banking system

Reserve money 3/

Net credit to the central government by the banking system

Domestic fiscal balance

Primary fiscal balance

Social spending

Priority spending

Exceptional spending

Net accumulation of domestic arrears

New nonconcessional external debt

Short-term external debt

\section{Continuous quantitative performance criteria}

Stock of outstanding nonreschedulable external arrears

Indicative targets

Broad money 4/

$\begin{array}{cccccc}\text { Met } & \text { Met } & \text { Met } & \text { Met } & \text { Not met } & \text { Met } \\ \text { Met } & \text { Not met } & & & & \\ \text { Met } & \text { Not met } & \text { Met } & \text { Met } & \text { Not met } & \text { Met } \\ \text { Met } & \text { Met } & \text { Met } & \text { Met } & \text { Not met } & \text { Met } \\ & & \text { Not met } & \text { Not met } & \text { Not met } & \text { Met } \\ \text { Met } & \text { Met } & & & & \\ \text { Met } & & & & & \\ & \text { Met } & \text { Met } & \text { Met } & \text { Met } & \text { Not met } \\ & & \text { Met } & \text { Met } & \text { Met } & \\ \text { Met } & \text { Met } & \text { Not met } & \text { Not met } & \text { Not met } & \text { Met } \\ \text { Met } & \text { Met } & \text { Met } & \text { Not met } & \text { Not met } & \text { Met } \\ \text { Met } & \text { Met } & \text { Met } & \text { Met } & \text { Met } & \text { Met }\end{array}$

Not met Met Not met Met Not net met 
Table 7. Rwanda: Observance of Quantitative and Structural Performance Criteria and Benchmarks under the PRGF Arrangements 2001-04 1/ (continued)

\section{Structural performance criteria}

Begin collecting taxes under VAT law

Ensure that the National Bank of Rwanda conducts weekly

Complete a comprehensive review of all tax exonerations,

\section{Structural Benchmarks}

Develop a system for monitoring poverty-related expenditures 
Table 7. Rwanda: Observance of Quantitative and Structural Performance Criteria and Benchmarks under the PRGF Arrangements 2001-04 1/ (concluded)

\begin{tabular}{|c|c|c|}
\hline & Test Date & Status \\
\hline $\begin{array}{l}\text { Ensure that the NBR, the MoF, the Ministry of Justice, and the } \\
\text { Bankers' Association will jointly prepare an action plan to } \\
\text { improve the legal environment to facilitate stronger loan recovery }\end{array}$ & End-December 2002 & Not met \\
\hline $\begin{array}{l}\text { Complete the report on implementation of the } 2002 \text { development } \\
\text { budget }\end{array}$ & End-June 2003 & Not met \\
\hline Issue the tender for the sale of Rwanda Commercial Bank & End-June 2003 & Not met \\
\hline Issue list of overdue obligations scheduled for clearance in 2003 & End-June 2003 & Not met \\
\hline $\begin{array}{l}\text { Establish written procedures to ensure the monetary data } \\
\text { used for program purposes are in accordance with TMU }\end{array}$ & End-August 2003 & Not met \\
\hline $\begin{array}{l}\text { Issue action plan for the closure of dormant accounts and } \\
\text { accounts operating outside of controlling regulations }\end{array}$ & End-September 2003 & Met \\
\hline $\begin{array}{l}\text { Implement a monthly reporting mechanism for the financial } \\
\text { operations of all districts }\end{array}$ & End-September 2003 & Not met \\
\hline Submit Organic Law to parliament & End-September 2003 & Not met \\
\hline Operationalize the NBR's Internal Audit Department & End-December 2003 & Met \\
\hline $\begin{array}{l}\text { External audit firm to complete the audit of the NBR's } 2003 \\
\text { financial statements }\end{array}$ & End-June 2004 & Not met \\
\hline $\begin{array}{l}\text { Finalization of action plans for bringing banks into full } \\
\text { compliance with banking regulations by 12/31/04 }\end{array}$ & End-June 2004 & Not met \\
\hline Cabinet approval for export promotion action plan & End-September 2004 & Met \\
\hline
\end{tabular}

1/ There have been changes in the program design during 2000-04. Three reviews (December 2002 and June and December 2003) had a performance criterion on exceptional spending. Moreover, several PCs were changed:

- the performance criterion on net domestic assets was replaced by a performance criterion on reserve money;

- the performance criterion on the primary fiscal balance was replaced by a performance criterion on the domestic fiscal balance;

- the performance criterion on social spending was replaced by a performance criterion on priority spending;

2/ The review was not completed as a result of delays in reaching agreement on the 2002 budget and the medium-term framework.

3/ Until 2001 indicative target; from 2002 onward performance criterion.

4/ Became indicative target in 2002. 
Table 8. Rwanda: Nominal and Net Present Value of External Debt Outstanding at End-1999 ${ }^{1 /}$

(In millions of U.S. dollars)

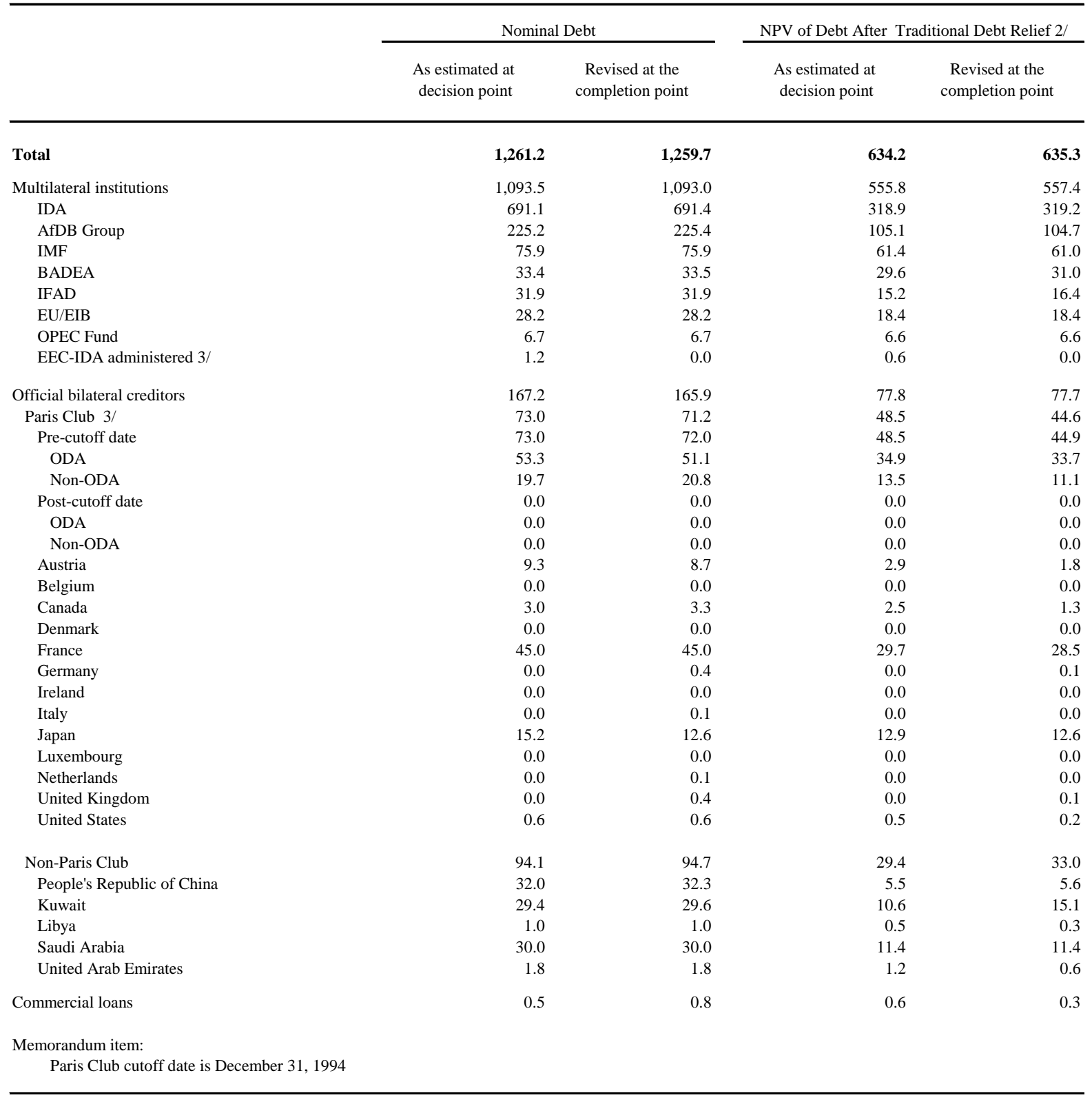

Sources: Rwandese authorities; and IDA and IMF staff estimates.

$1 /$ Refers to public and publicly garanteed external debt.

2/ After full use of traditional debt-relief mechanism, and comparable treatment from non-Paris Club creditors.

3/ Several European Union loans were incorrectly classified as multilateral at the decision point. In February 2005, the Commission of the European

Union, after consultation with its member states, notified staffs that these loans should be classified as bilateral to reflect the correct ownership status they had since 1978. 


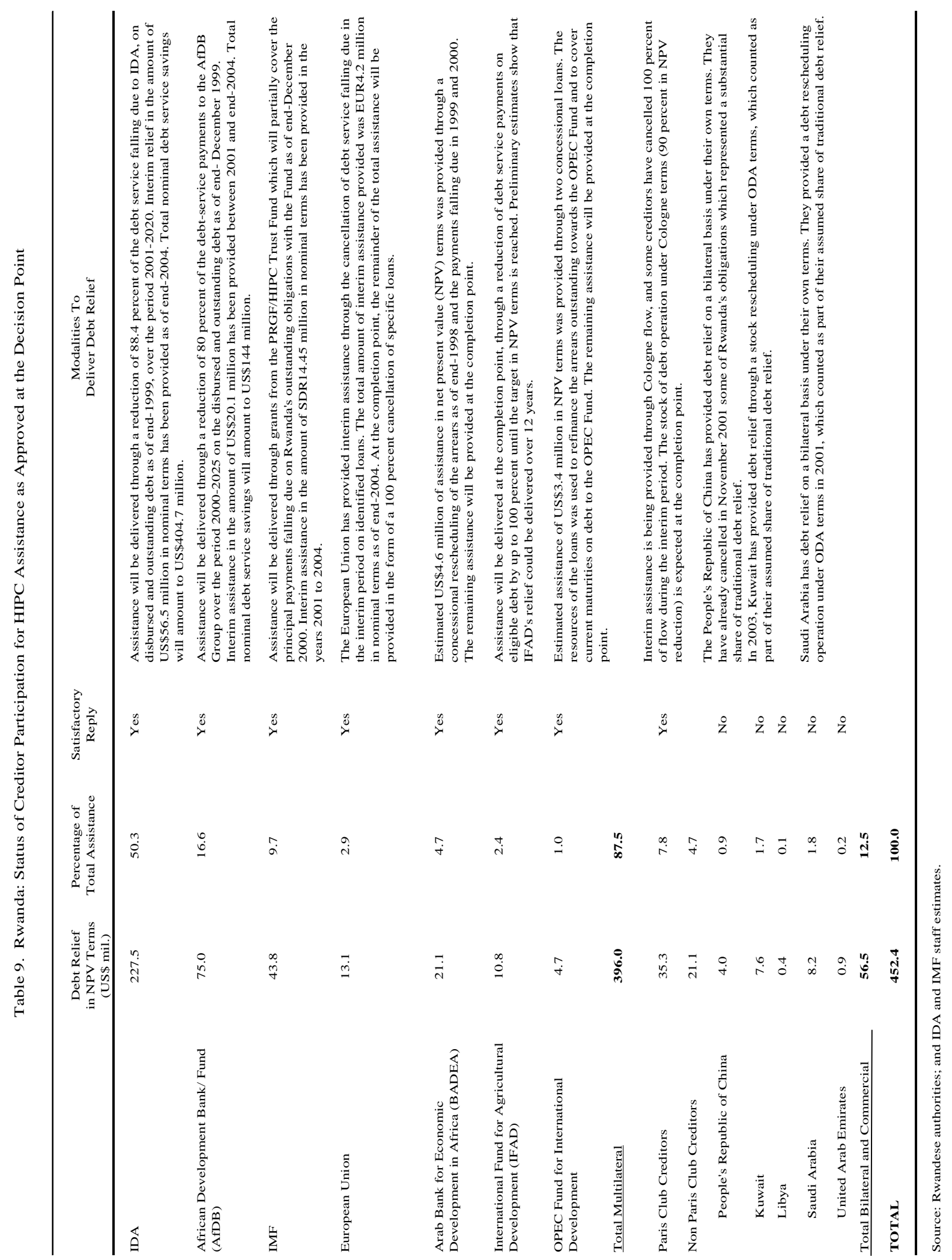




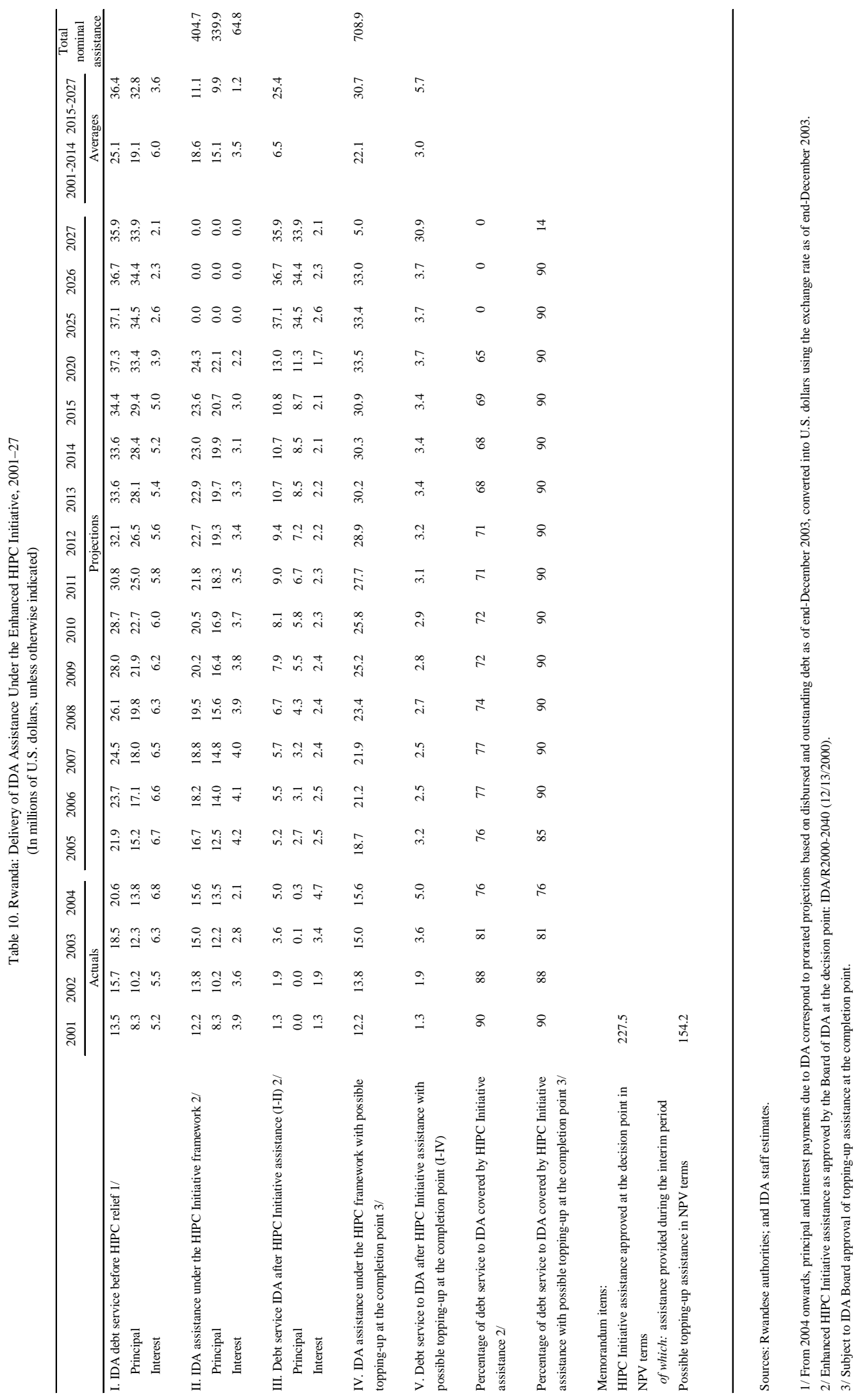


Table 11. Rwanda: Delivery of IMF Assistance Under the Enhanced HIPC Initiative, 2000-10

(In millions of SDRs, unless otherwise indicated)

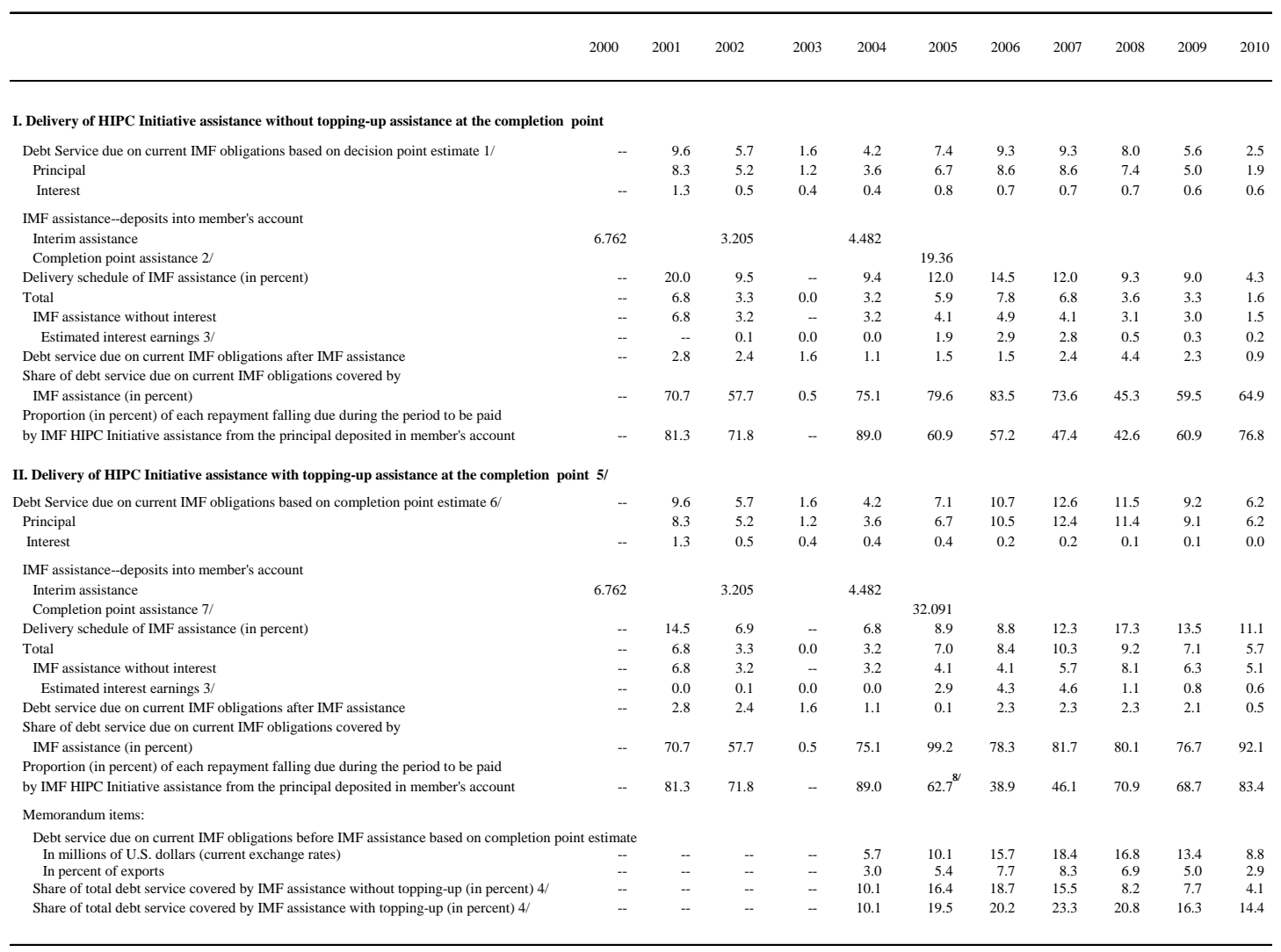

Source: IMF staff estimates and projections.

1/ Forthcoming obligations estimated based on rates and principal schedules in effect as of October 31, 2000. Interest obligations include net SDR charges and assessments.

2/ A final disbursement of SDR 19.361 million assumed to be disbursed into member's account at the enhanced HIPC completion point in April 2005.

3/ Includes estimated interest earnings on: (1) amounts held in member's account; and (2) amounts committed but not yet disbursed up to the second completion point. It is assumed that these amounts earn a rate of return of 5 percent in SDR terms; actual interest earnings may be higher or lower. Interest accrued on (1) during a calendar year will be used toward the first repayment obligations falling due in the following calendar year except in the final year, when it will be used toward payment of the final obligations falling due in that year. Interest accrued on (2) during the interim period will be used toward the repayment of obligations falling due during the three years after the completion point.

5/ Total IMF assistance under the HIPC Initiative is [SDR 46.54] million including topping-up assistance, and excluding interest earned on Rwanda's account and on committed but undisbursed amounts as described in footnote 4. The topping-up assistance of [SDR 12.73] million will be updated using the US\$/SDR exchange rate at the completion point and disbursed to Rwanda, with accrued interest, when satisfactory financing assurances for the disbursement of such amount have been obtained.

6/ Forthcoming obligations estimated based on rates and principal schedules in effect as of December 31, 2004, i.e. at the end of the quarter before the Board's consideration of the enhanced HIPC completion point. Actual interest obligations include SDR Department charges and fees.

7/ A final disbursement of [SDR 32.091] million (plus accrued interest) is assumed to be disbursed into Rwanda's account at the enhanced HIPC completion point in April 2005. This includes topping up of SDR 12.73 million at the SDR/USS exchange rate of 0.649786 on March 11, 2005 .

8/ The proportion of 60.9 percent was approved by the Board at the time of the request for additional interim assistance to cover principal repayment obligations falling due between January 1 and June 8,2005 . The proportion of 62.7 percent will be applied to principal repayment obligations for the remainder of 2005. 


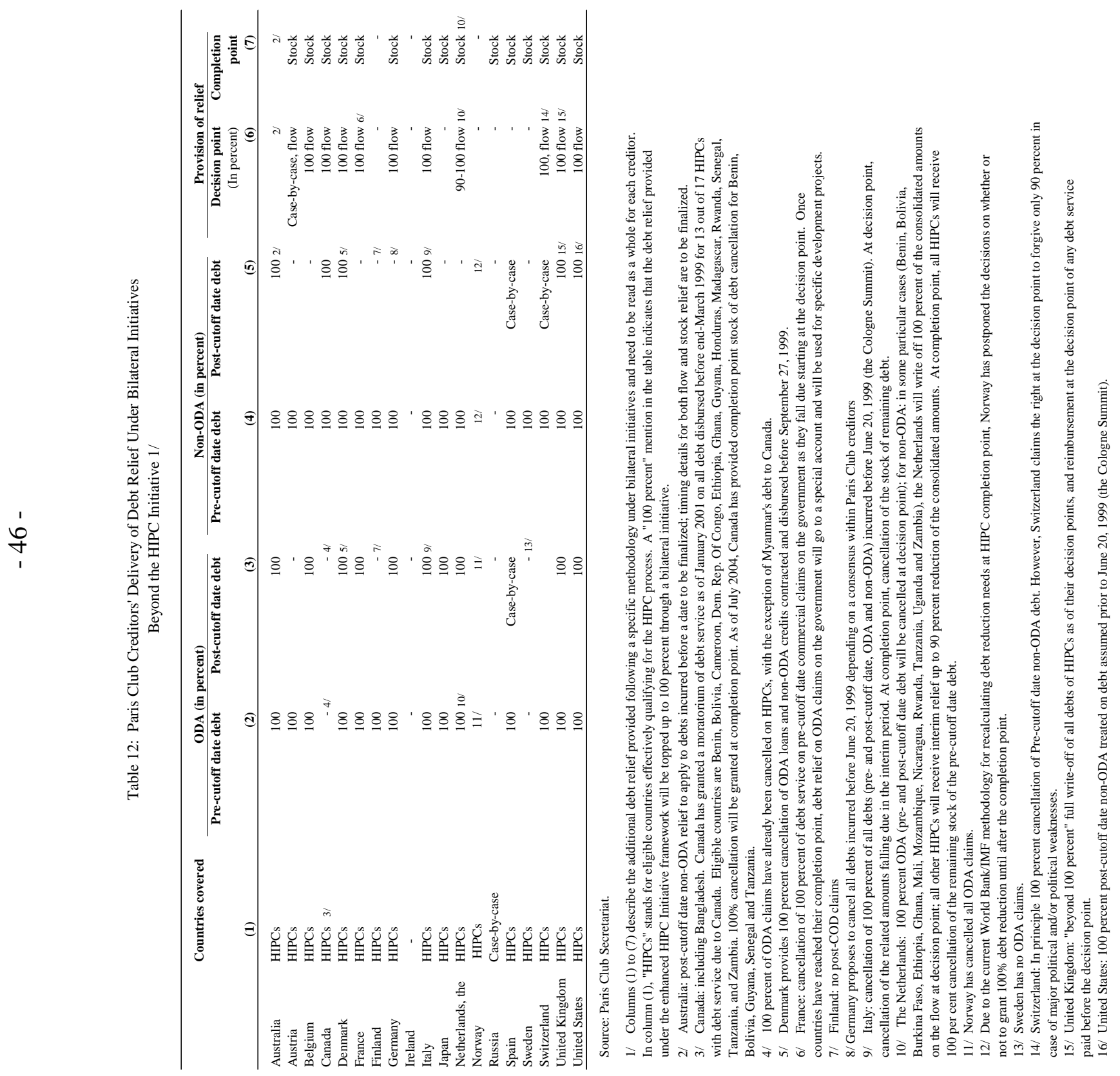




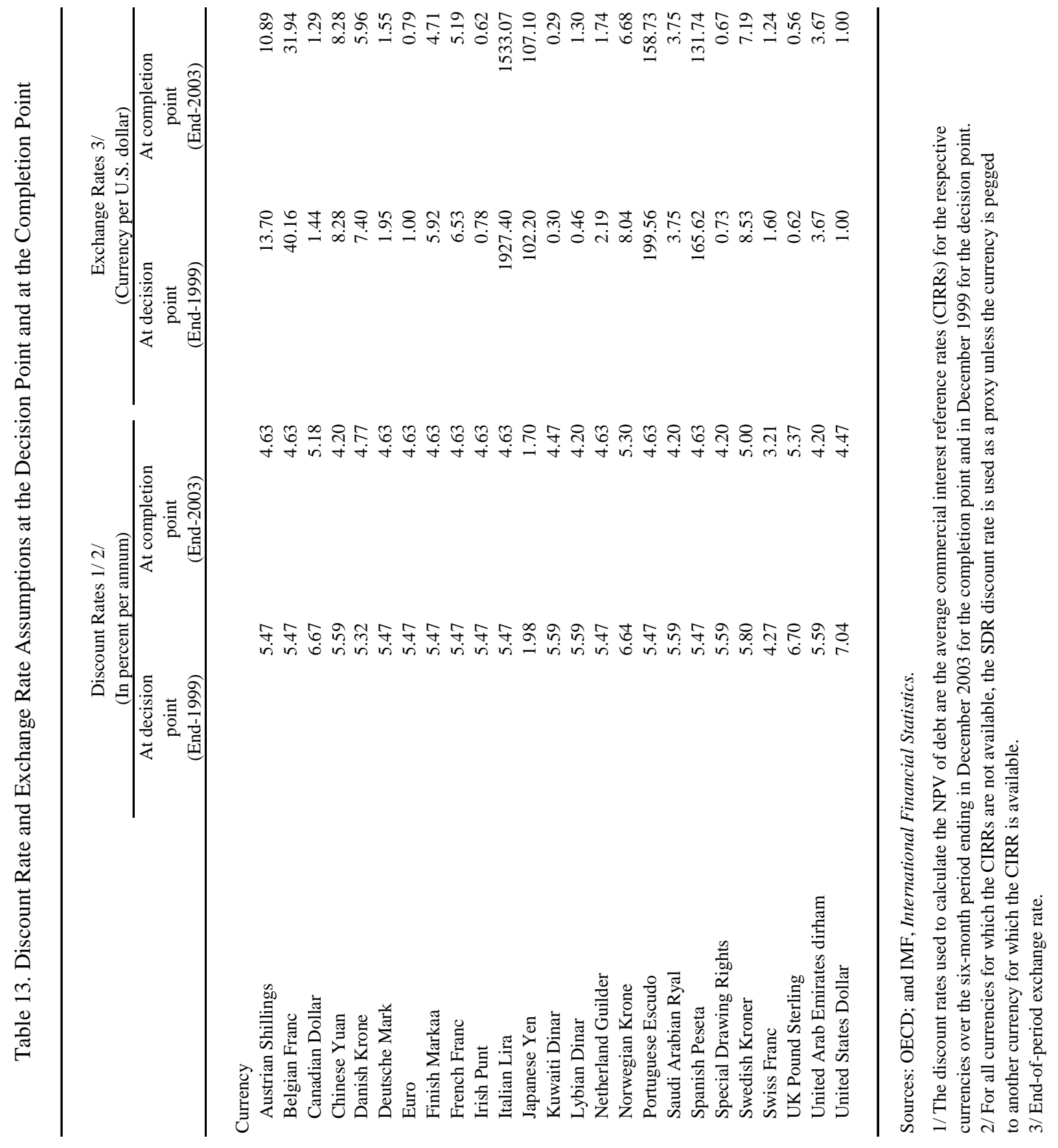


Table 14. Rwanda: Nominal and Net Present Value of External Debt Outstanding at End-2003 1/ (In millions of U.S. dollars, unless otherwise indicated)

\begin{tabular}{|c|c|c|c|c|c|c|}
\hline & \multicolumn{2}{|c|}{ Legal Situation 2/ } & \multicolumn{4}{|c|}{ Net Present Value of Debt } \\
\hline & Nominal debt & NPV of debt & $\begin{array}{l}\text { After enhanced } \\
\text { HIPC } \\
\text { relief }\end{array}$ & $\begin{array}{l}\text { After additional } \\
\text { bilateral relief }\end{array}$ & $\begin{array}{c}\text { After additional } \\
\text { bilateral } \\
\text { (in percent) } \\
\text { of total debt) }\end{array}$ & $\begin{array}{c}\text { Topping-up amount } \\
\text { at the } \\
\text { completion point } \\
\text { in } 2005 \mathrm{NPV} \text { terms }\end{array}$ \\
\hline Total & $1,572.5$ & $1,009.2$ & 467.1 & 457.7 & 100.0 & 243.1 \\
\hline Multilateral & $1,388.8$ & 867.0 & 441.5 & 441.5 & 96.5 & 234.5 \\
\hline IDA & 912.9 & 539.5 & 290.3 & 290.3 & 63.4 & 154.2 \\
\hline AfDB Group & 263.4 & 159.0 & 77.4 & 77.4 & 16.9 & 41.1 \\
\hline $\mathrm{IMF}$ & 91.9 & 78.6 & 36.9 & 36.9 & 8.1 & 19.6 \\
\hline IFAD & 50.4 & 31.3 & 16.1 & 16.1 & 3.5 & 8.6 \\
\hline EU/EIB & 30.9 & 22.9 & 6.0 & 6.0 & 1.3 & 3.2 \\
\hline BADEA & 21.7 & 20.3 & 6.0 & 6.0 & 1.3 & 3.2 \\
\hline OPEC Fund & 16.7 & 14.4 & 7.8 & 7.8 & 1.7 & 4.1 \\
\hline Shelter Afrique & 0.9 & 1.0 & 1.0 & 1.0 & 0.2 & 0.5 \\
\hline Official bilateral creditors & 183.7 & 142.3 & 25.6 & 16.2 & 3.5 & 8.6 \\
\hline Paris Club 3/ 4/ & 88.9 & 76.0 & 9.4 & - & 0.0 & - \\
\hline Pre-cutoff date & 88.9 & 76.0 & 9.4 & 0.0 & 0.0 & 0.0 \\
\hline ODA & 66.5 & 55.1 & 9.4 & 0.0 & 0.0 & 0.0 \\
\hline Non-ODA & 22.4 & 20.9 & 0.0 & 0.0 & 0.0 & 0.0 \\
\hline Post-cutoff date & - & - & - & - & 0.0 & - \\
\hline ODA & - & - & - & - & 0.0 & - \\
\hline Non-ODA & - & - & - & - & 0.0 & - \\
\hline Austria & 10.0 & 7.6 & $\ldots$ & $\ldots$ & $\ldots$ & $\ldots$ \\
\hline Belgium & 0.0 & 0.0 & $\ldots$ & $\ldots$ & $\ldots$ & $\ldots$ \\
\hline Canada & 2.6 & 1.7 & $\ldots$ & $\ldots$ & $\ldots$ & $\ldots$ \\
\hline Denmark & 0.0 & 0.0 & $\ldots$ & $\ldots$ & $\ldots$ & $\ldots$ \\
\hline France & 59.4 & 51.2 & $\ldots$ & $\ldots$ & $\ldots$ & $\ldots$ \\
\hline Germany & 0.5 & 0.3 & $\ldots$ & $\ldots$ & $\ldots$ & $\ldots$ \\
\hline Ireland & 0.0 & 0.0 & $\ldots$ & $\ldots$ & $\ldots$ & $\ldots$ \\
\hline Italy & 0.1 & 0.0 & $\ldots$ & $\ldots$ & $\ldots$ & $\ldots$ \\
\hline Japan & 14.4 & 12.9 & $\ldots$ & $\ldots$ & $\ldots$ & $\ldots$ \\
\hline Luxembourg & 0.0 & 0.0 & $\ldots$ & $\ldots$ & $\ldots$ & $\ldots$ \\
\hline Netherlands & 1.1 & 1.2 & $\ldots$ & $\ldots$ & $\ldots$ & $\ldots$ \\
\hline United Kingdom & 0.3 & 0.2 & $\ldots$ & $\ldots$ & $\ldots$ & $\ldots$ \\
\hline United States & 0.6 & 0.7 & $\ldots$ & $\ldots$ & $\ldots$ & $\ldots$ \\
\hline Non-Paris Club & 94.8 & 66.3 & 16.2 & 16.2 & 3.5 & 8.6 \\
\hline People's Republic of China & 29.7 & 26.9 & 13.9 & 13.9 & 3.0 & 7.4 \\
\hline Kuwait & 32.0 & 17.4 & - & - & 0.0 & - \\
\hline Libya & 0.4 & 0.4 & - & - & 0.0 & - \\
\hline Saudi Arabia & 30.2 & 19.1 & 2.1 & 2.1 & 0.5 & 1.1 \\
\hline United Arab Emirates & 2.5 & 2.5 & 0.3 & 0.3 & 0.1 & 0.1 \\
\hline Commercial loans 5/ & - & - & - & - & 0.0 & - \\
\hline \multicolumn{7}{|l|}{ Memoradum item: } \\
\hline
\end{tabular}

Sources: Rwandese authorities; and IDA and IMF staff estimates.

1/ Figures are based on data as of December 31, 2003.

2/ Reflects the external debt situation as of end-2003, including a 1998 Paris Club flow rescheduling on Naples terms, topped-up to a flow rescheduling on Cologne terms in 2002. 3/ Paris Club creditors deliver their share of assistance as a group. Actual delivery modalities are defined on a case-by-case basis.

4/ Several European Union loans were incorrectly classified as multilateral at the decision point. In February 2005, the Commission of the European Union, after consultation with its member states, notified staffs that these loans should be classified as bilateral to reflect the correct ownership status they had since 1978 .

5/ As of 2002, the commercial loans at the decision point are classified as Paris Club bilateral loans. 


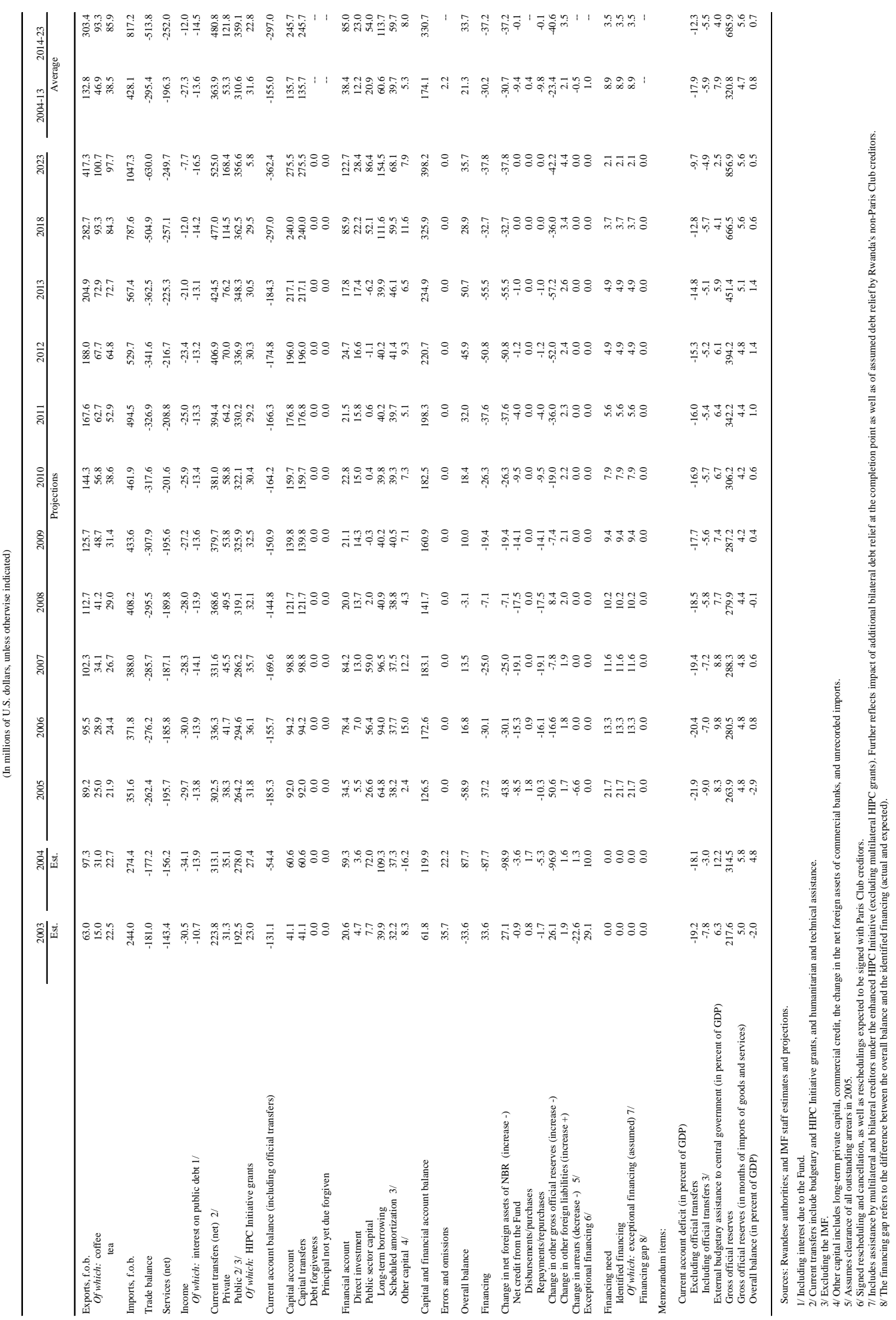




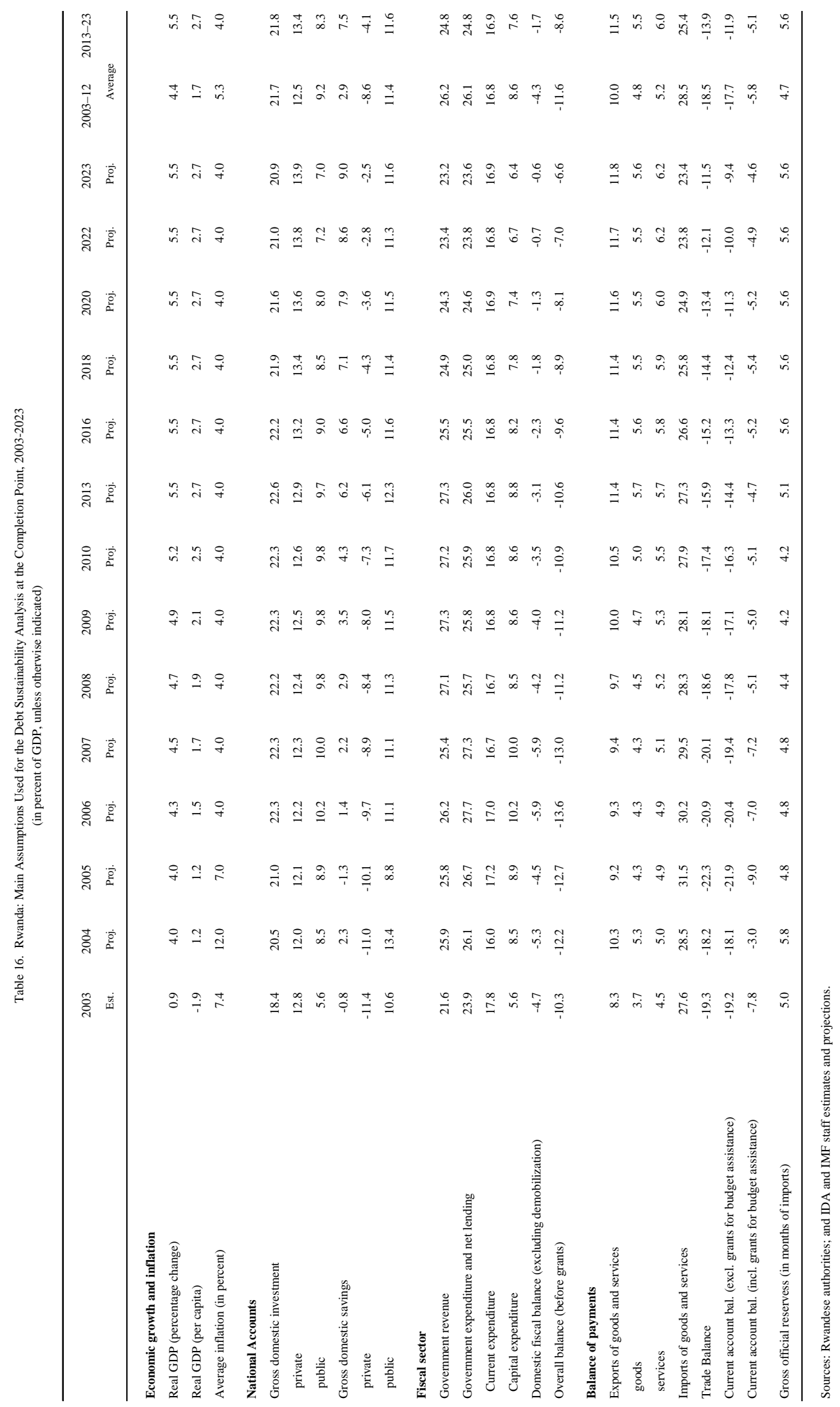




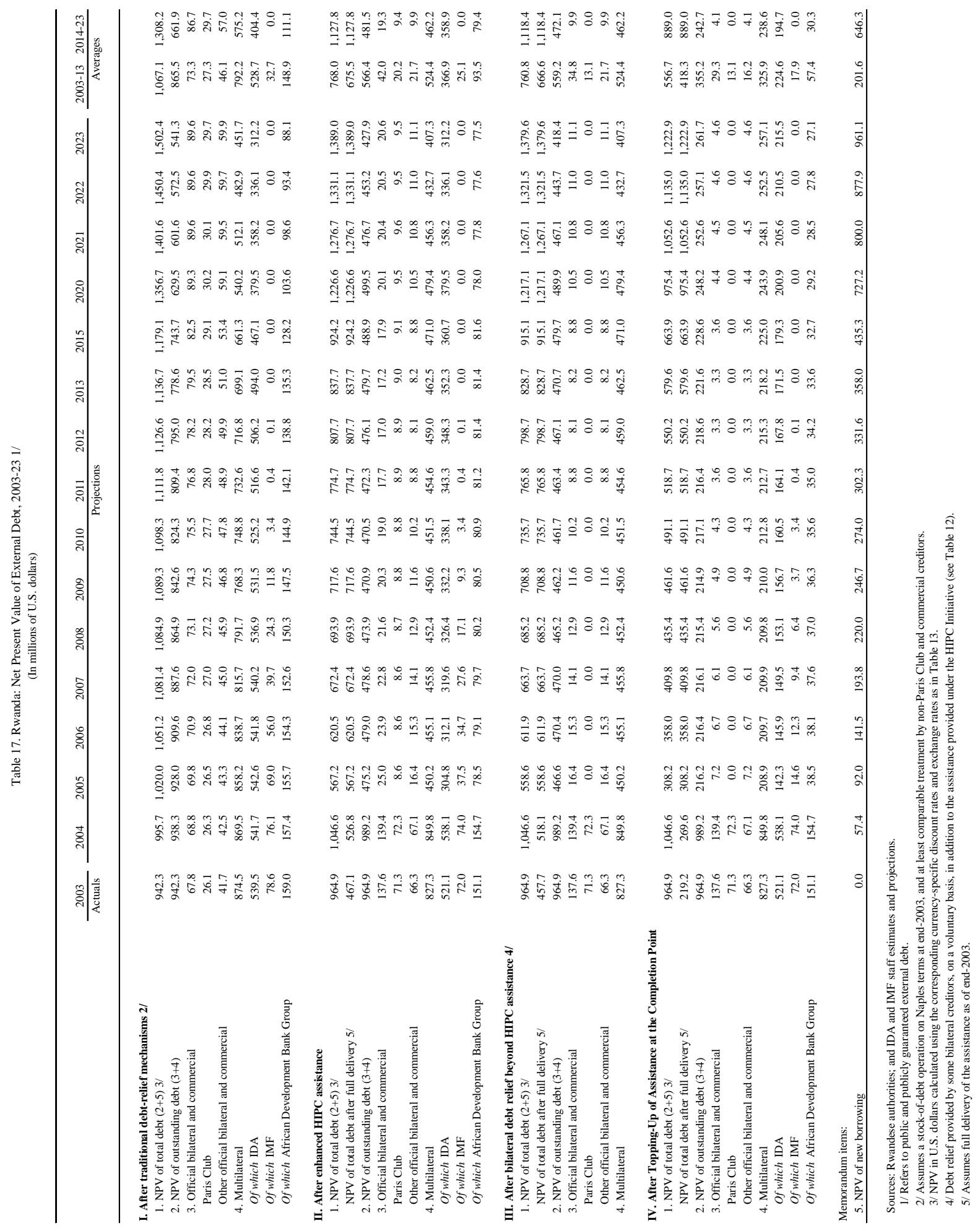




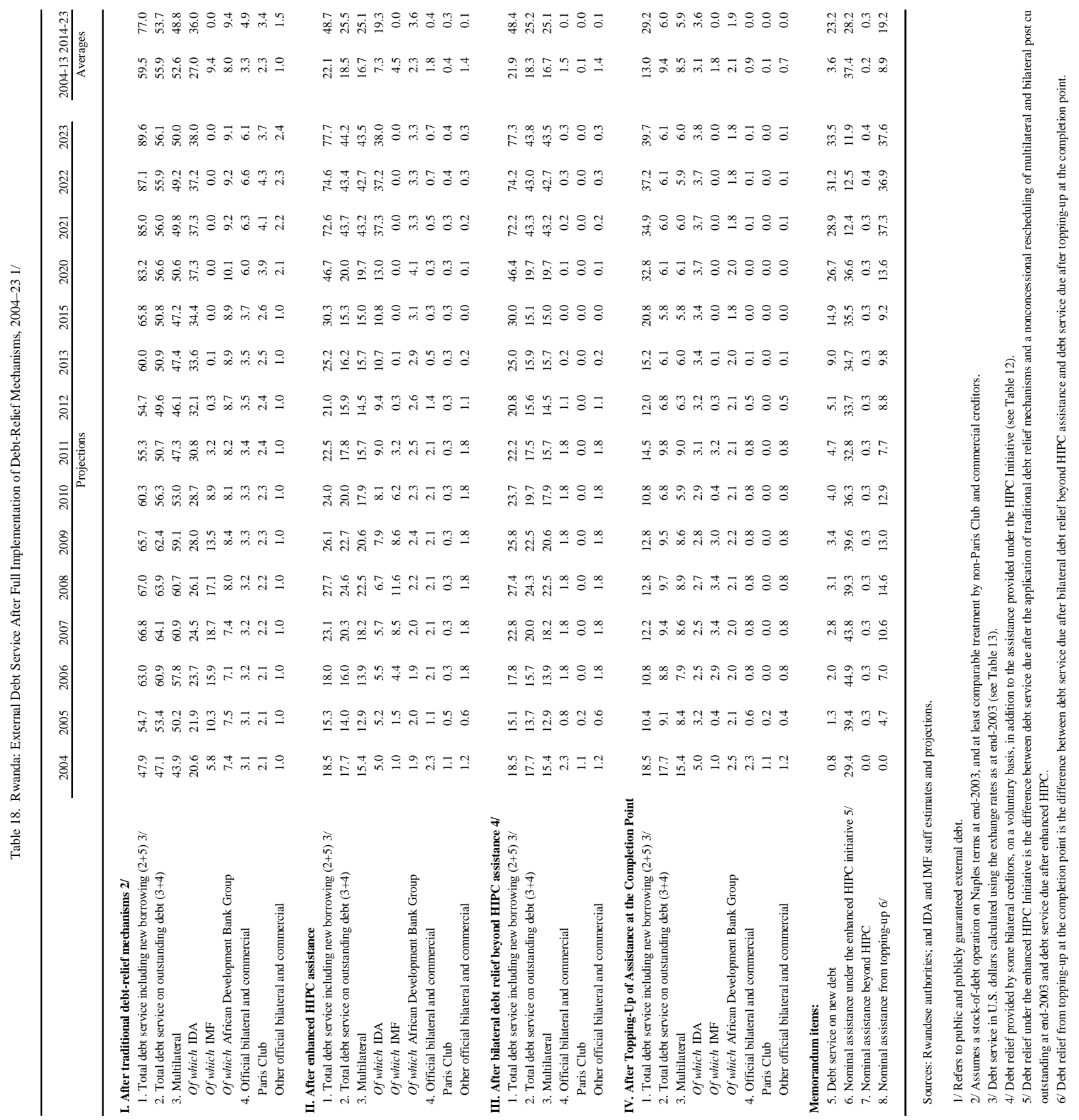




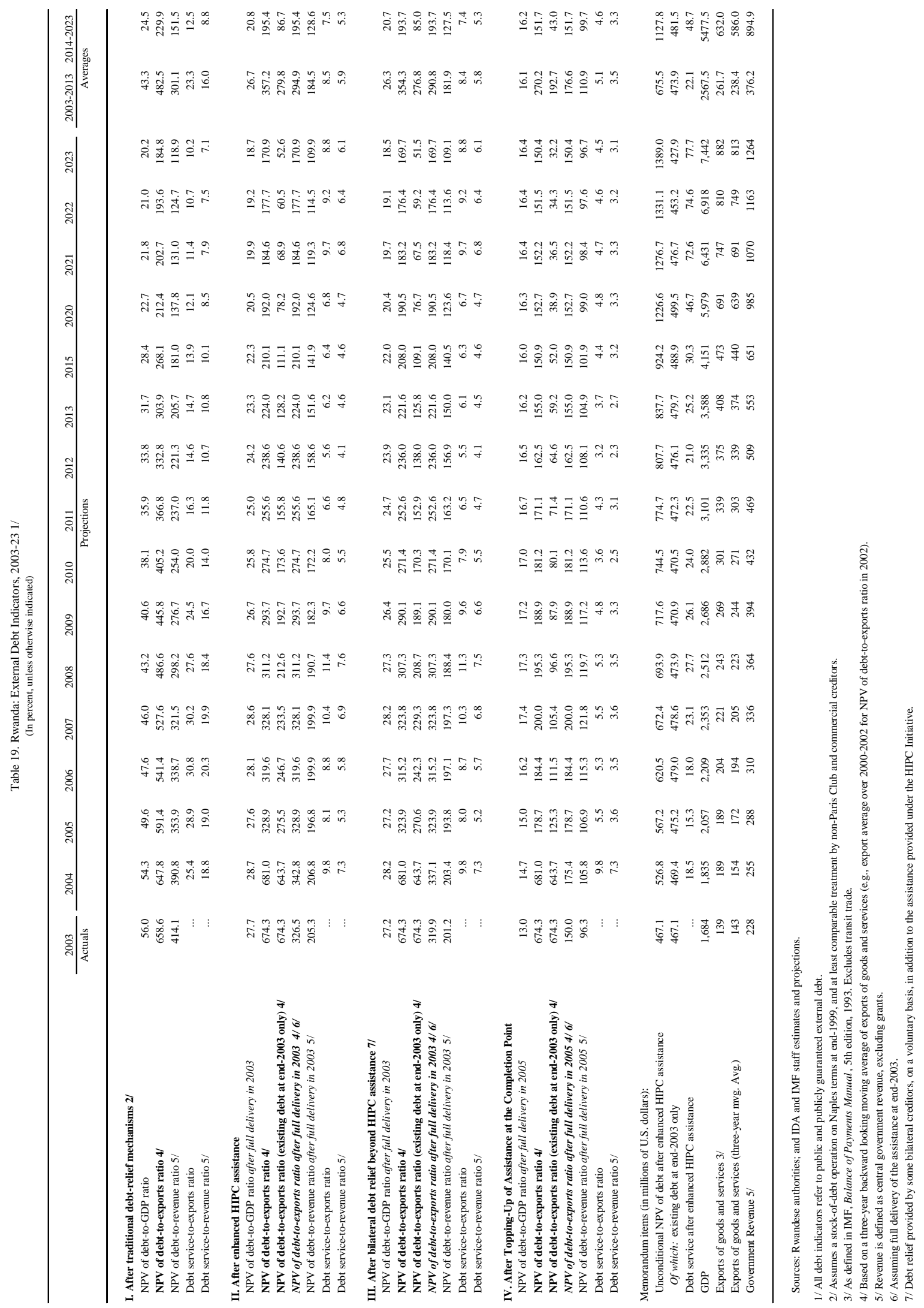




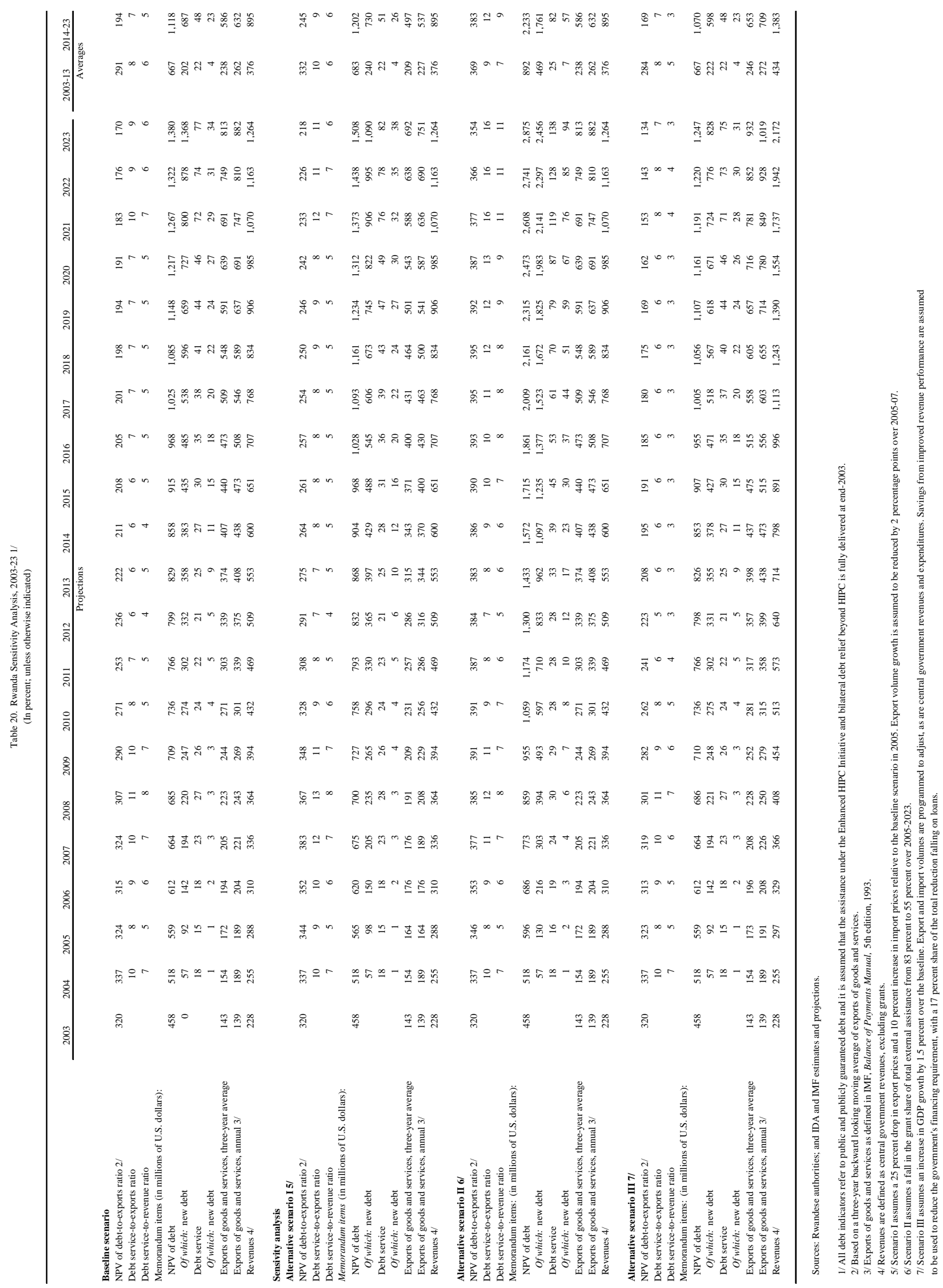




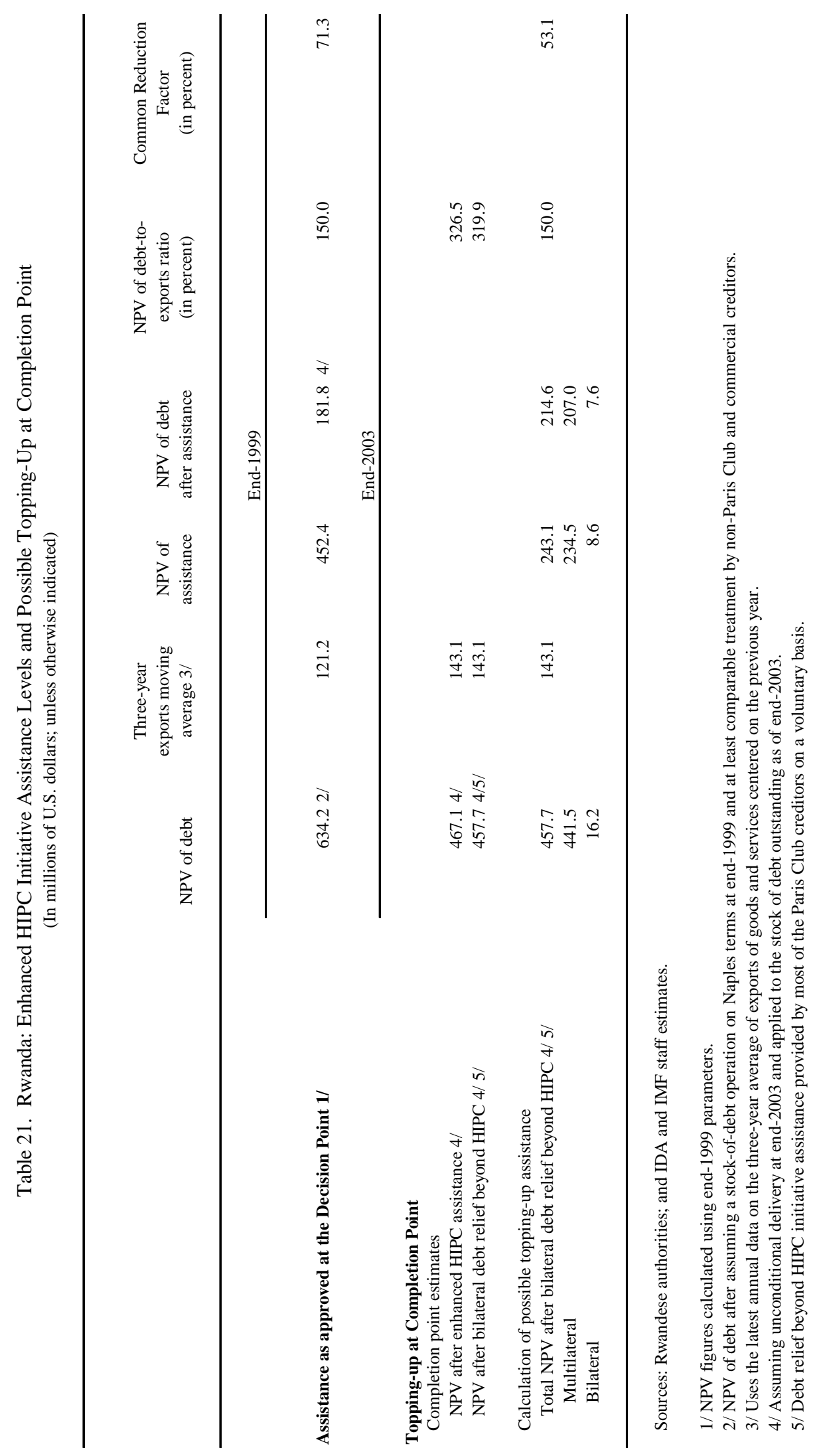


Table 22. HIPC Initiative: Status of Country Cases Considered Under the Initiative, February 11, 2005

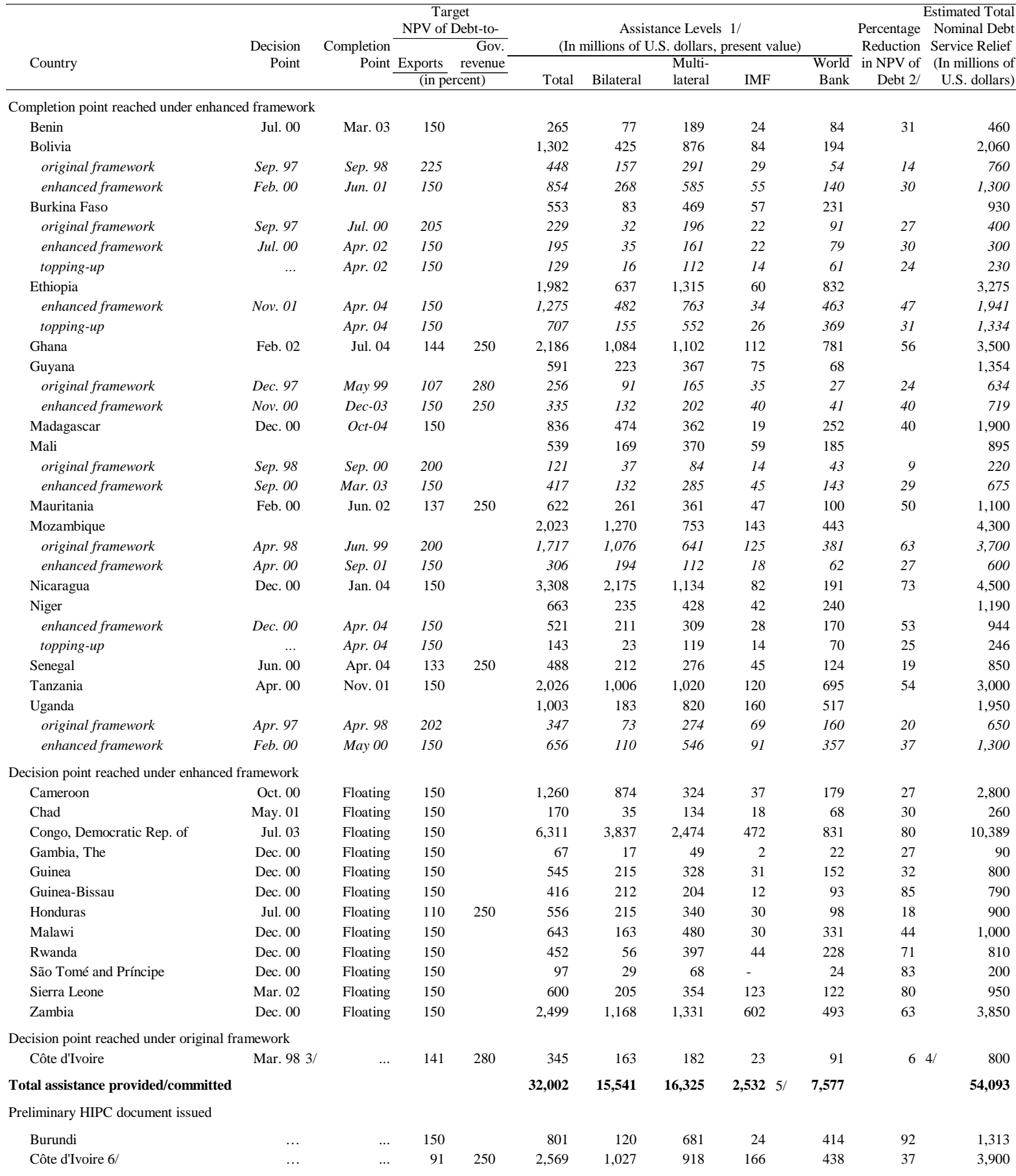

Sources: IMF and World Bank Board decisions, completion point documents, decision point documents, preliminary HIPC documents, and staff calculations.

1/ Assistance levels are at countries' respective decision or completion points, as applicable.

2/ In percent of the net present value of debt at the decision or completion point (as applicable), after the full use of traditional debt-relief mechanisms.

3/ Côte d'Ivoire reached its decision point under the original framework in March 1998. The total amount of assistance committed thereunder was US\$345 million in NPV term

4/ Nonreschedulable debt to non-Paris Club official bilateral creditors and the London Club, which was already subject to a highly concessional restructuring, is

excluded from the NPVof debt at the completion point in the calculation of this ratio.

5/ Equivalent to SDR 1,718 million at an SDR/USD exchange rate of 0.6635, as of February 11, 2005.

6/ It is suggested that enhanced HIPC relief for Côte d'Ivoire overtake the commitments made under the original HIPC framework. 


\section{Public Debt Management}

1. The responsibility for public debt management is shared among different bodies within the government of Rwanda. The Public Debt Division (DPP) at the Ministry of Finance (MINECOFIN) maintains the debt database and is responsible for ensuring the servicing of external obligations. Actual payments are made by the "Département de l'inspection du change et balance de paiements" at the National Bank of Rwanda (NBR). Other divisions in the MINECOFIN are concerned with negotiating and contracting public external debt and granting public guarantees. The Central Projects and External Finance Bureau (CEPEX), a semi-autonomous body in the MINECOFIN, is tasked with coordinating external financing activities by line ministries, by sector priority, and by donor.

2. The "Sous-comité de gestion de la dette" is in charge of the coordination between these different agencies. Its effectiveness, however, is hampered by the absence of a legal mandate and the irregularity of its coordination meetings. As a result, the Committee is not able to effectively channel or facilitate the flow of information. In this regard, it is necessary to empower it with an explicit and clear legal mandate. ${ }^{36}$

\section{Rwanda's legal framework for debt management would also need to be strengthened to place stronger emphasis on public disclosure of both public debt management policies and reports on public debt.}

\section{A. Policy Coordination and Debt Strategy}

4. The main responsibility for decisions regarding new borrowing is with the MINECOFIN. The contracting of new loans and granting of guarantees is the responsibility of the MINECOFIN, subject to parliamentary approval. In the process, MINECOFIN seeks technical advice from its own debt office and the NBR regarding the terms of the new loans and from CEPEX on the allocation of new financing to priority sectors. Only to a lesser extent do decisions on new borrowing take into account the impact of additional loans on the medium- and long-term macroeconomic outlook.

5. Evaluations of new borrowing are done mainly in the context of their compliance with the concessionality requirements set out in the PRGF arrangement. Under the current PRGF arrangement, new borrowing is strictly limited to loans with a grant element of 50 percent or more. This policy applies to the contracting and

\footnotetext{
${ }^{36}$ Such a mandate could include (a) coordination of debt management activities; (b) establishment of a channel for a regular and reliable flow of information; (c) formulation and follow up of the country's debt strategy; (d) periodical analysis of the debt management framework and proposals for its improvement; (e) technical analysis of new borrowing proposals, including a recommendation to the Minister of Finance; and (f) elaboration of a disclosure policy, aiming at enhancing the accountability of the agencies participating in the debt management process by making the debt policy and its results public.
} 
guaranteeing of new long-term borrowing by the central government, local governments, and the NBR.

\section{B. Data Recording and Reporting}

6. Two institutions record debt data in Rwanda, the MINECOFIN and the NBR. The DDP at MINECOFIN records external central government debt. In parallel, the NBR also records debt data, but with a more comprehensive coverage. For example, domestic debt is solely recorded at the NBR. By means of a questionnaire that is sent out on a regular basis, the NBR also maintains a database on public enterprise and publicly guaranteed external private debt.

7. The quality of debt data recording could be enhanced by improved access to debt documentation and the installation in a network of a debt recording software. Fairly good documentation on public sector debt is maintained in both institutions; however, weak archiving practices make any data reconciliation efforts unnecessarily cumbersome. Only the MINECOFIN is using UNCTAD's database system DMFAS 5.2 (DMFAS was first installed in 1990 and the last update to version 5.2. took place in November 2000). Staff has been trained in the use of DMFAS at the MINECOFIN but many trained staff have left the ministry since. In parallel, the NBR maintains its own database in an excel environment. An interface between the two institutions is lacking and a reconciliation of the two databases is time intensive and therefore only carried out on an irregular basis. It is based mainly on informal efforts by staffs of both institutions.

8. Inconsistencies between the two datasets has led, and could lead, to discrepancies between debt data in the budget and in the balance of payments. The DDP provides debt statistics for the budget; on the other hand, debt statistics included in the balance of payments originate from the NBR. Despite the reconciliation efforts by the two institutions, consistency of numbers across government publications could not be ensured in the past. Effective reconciliation and management of the databases in the MINECOFIN and NBR will be critical in order to ensure reliable debt data.

\section{Analytical Capacity and Staffing}

9. There is a need to build the capacity of staff on all aspects of debt management, ranging from interpretation of loan agreements and reports sent by creditors to the use of the debt recording system and formulation of DSAs. Some training has been provided by Debt Relief International and UNCTAD. However, awareness of debt restructuring options and sustainability issues is limited to a few individuals. Further technical assistance aiming to ensure a wider dispersion of debt management skills throughout the staff, and to assist in integrating debt simulations with macroeconomic projections, should be a priority.

10. In addition, the number of staff with sufficient training to carry out even basic debt management functions seems inadequate. Since 1998, the DDP has experienced a significant reduction in the number of staff: from 8 staff in 1998 it shrank 
to only 3 in 2004. As a result, carrying out the functions of the DDP (as outlined in the "Cadre organique du ministère de finances") represents a challenge. Going forward, it will be vital for the government to attract and retain into its debt management team skilled personnel. 


\section{Debt Sustainability Analysis for Low-Income Countries Framework}

1. The IDA and the IMF have proposed a forward-looking framework for debt sustainability for low-income countries (LIC framework). ${ }^{37}$ This appendix presents the projected path of Rwanda's debt burden indicators under the LIC framework methodology and draws some conclusions on the forward-looking sustainability of the country's sovereign external debt.

2. The results under the baseline scenario indicate that, even after full delivery of HIPC assistance and additional bilateral debt relief, Rwanda faces a high risk of debt distress (see Appendix II, Table 1). Using the LIC framework, Rwanda's NPV of debt as of end-2003, after full delivery of HIPC assistance and additional bilateral debt relief, ${ }^{38}$ is estimated at US\$398 million, equivalent to 286 percent of exports. ${ }^{39}$ In the following years, the NPV of debt-to-exports ratio is projected to increase and peak at 267 percent in 2007. Thereafter, it falls gradually to reach the 137 percent by 2024 (see Appendix II, Figure 1). The NPV of external debt-to-GDP ratio follows a similar pattern: from 24 percent at end-2003, the ratio increases to 25 percent by end-2007, and then decreases gradually to about 16 percent by the end of the analysis period. Finally, the external debt service representing about 11 percent of export revenue in 2003 decreases gradually to levels around 6 to 7 percent until 2020, after which it increases sharply above 9 percent as concessional debt comes to maturity and debt service reduction under the HIPC Initiative is exhausted. An overall assessment would point out that, even if liquidity indicators suggest that a distress situation is a distant concern, they do not provide sufficient comfort against the high level of the exports-based stock indicator.

\section{When compared with Rwanda's historical performance, it becomes clear} that both an increased reliance on grant financing and the success of the export promotion strategy are key to realize the projections in the baseline scenario. The proposed LIC framework suggests an alternative scenario in which the main parameters that determine the debt dynamics are assumed to remain at their historical averages. ${ }^{40}$ This "historical scenario" is intended to provide an indication about how optimistic the

\footnotetext{
${ }^{37}$ See “Debt Sustainability in Low-Income Countries: Proposal for an Operational Framework and Policy Implications" and "Debt Sustainability in Low-Income Countries: Further Considerations on an Operational Framework and Policy Implications”.

${ }^{38}$ Unless otherwise indicated, all debt ratios in this section assume full delivery of HIPC assistance (as approved at the decision point) and bilateral debt relief beyond HIPC.

${ }^{39}$ This compares to 320 percent under the HIPC methodology. Appendix II Box 1, presents the methodological differences between the HIPC framework and the LIC framework in the calculation of the NPV of debt-to-exports ratio, as well as the impact of such differences on the ratio.

${ }^{40}$ Under this scenario, real GDP growth, inflation, the noninterest current account in percent of GDP, and non-debt-creating flows in percent of GDP are assumed to remain at their ten-year historic averages.
} 
baseline is relative to the country's own past performance. As shown in Appendix II, Figure 1, all debt burden indicators under the "historical scenario" present a significant deterioration compared to the baseline. In particular, the debt service-to-exports ratio exhibits an upward trend and by the end of the projection period, it would reach 61 percent, more than six times the level projected under the baseline. The significant deterioration of debt and debt service indicators under the "historical scenario" underlines the critical importance of realizing the ambitious export growth projections under the baseline in terms of exports performance and grant financing. ${ }^{41}$

\section{Other stress tests give further evidence to Rwanda's vulnerability to adverse}

developments. Rwanda's debt indicators experience a considerable deterioration under most of the stress tests proposed under the LIC framework (see Appendix II, Table 2). In particular, the debt service-to-exports ratio is significantly affected when all main parameters determining the debt dynamics are assumed to be one-half standard deviation below their respective historical averages during the period 2005-06. Under this scenario, which represents a 25 percent probability of occurrence, the debt service-toexports ratio is projected to be twice as high by 2014 as in the baseline case.

\section{In summary, the projected path of the NPV of debt-to-exports ratio under} the baseline signals a high risk of debt distress despite low levels of the debt serviceto-exports ratio. Such a situation calls for increased reliance on grant financing with prudent new borrowing only on highly concessional terms. In this context, donors and creditors will need to coordinate carefully to ensure that external financing to support Rwanda's development goals is provided on terms compatible with longer-term debt sustainability. Equally important, the government needs to swiftly proceed with the implementation of its export promotion strategy, with a view to strengthen Rwanda's repayment capacity and reduce its vulnerability to shocks.

\footnotetext{
${ }^{41}$ In this context, it is important to note that even the optimistic baseline assumptions for export growth do not fully reflect the ambitious quantitative objective's set in the authorities' strategies for the coffee, tea, and tourism sectors.
} 


\section{Box 1. Impact of the Use of the LIC Framework Methodology on the End-2003 NPV of Debt-to-Exports Ratio}

Using the new LIC framework methodology, Rwanda's NPV of debt-to-exports ratio is estimated to have reached 286 percent at end-2003. This is 34 percentage points lower compared with the 320 percent obtained using the HIPC methodology. The increase is due to three factors:

(i) a 3 percentage points decrease is due to the change in the exchange rates used to calculate the projected debt service streams: projected exchange rates (from WEO) under the LIC framework versus end-2003 exchange rates under the HIPC methodology;

(ii) a 38 percentage points decrease is explained by the change in the discount rate used to calculate the NPV of debt: a single (5 percent) discount rate under the LIC framework versus currency-specific discount rates under the HIPC methodology; and

(iii) a 7 percentage points increase is due to the change in the denominator used to calculate the ratio: current exports under the LIC framework versus a three-year backward-looking average under the HIPC framework.

Table 1. Rwanda: Decomposition of the decrease in the NPV of debt-to-exports ratio at end-2003 1/ (in percentage points, unless otherwise indicated)

\begin{tabular}{|c|c|c|}
\hline Factors explaining the change in the NPV of & \multicolumn{2}{|c|}{ Impact of methodological changes } \\
\hline Total Change & \multicolumn{2}{|c|}{-34.3} \\
\hline \multicolumn{3}{|l|}{ Of which: due to changes in: } \\
\hline Exchange rates & \multicolumn{2}{|c|}{-3.2} \\
\hline Discount rates & \multicolumn{2}{|c|}{-38.3} \\
\hline Exports of goods and services & \multicolumn{2}{|c|}{7.2} \\
\hline \multicolumn{3}{|l|}{ Memorandum items: } \\
\hline & Completion point & LIC framework \\
\hline End-2003 NPV of debt-to-exports ratio & 319.9 & 285.6 \\
\hline \multicolumn{3}{|l|}{ Exports of goods and services } \\
\hline Current & 139.5 & 139.5 \\
\hline Three year average & 143.1 & 143.1 \\
\hline
\end{tabular}

1/ Refers to public and publicly guarenteed external debt. 


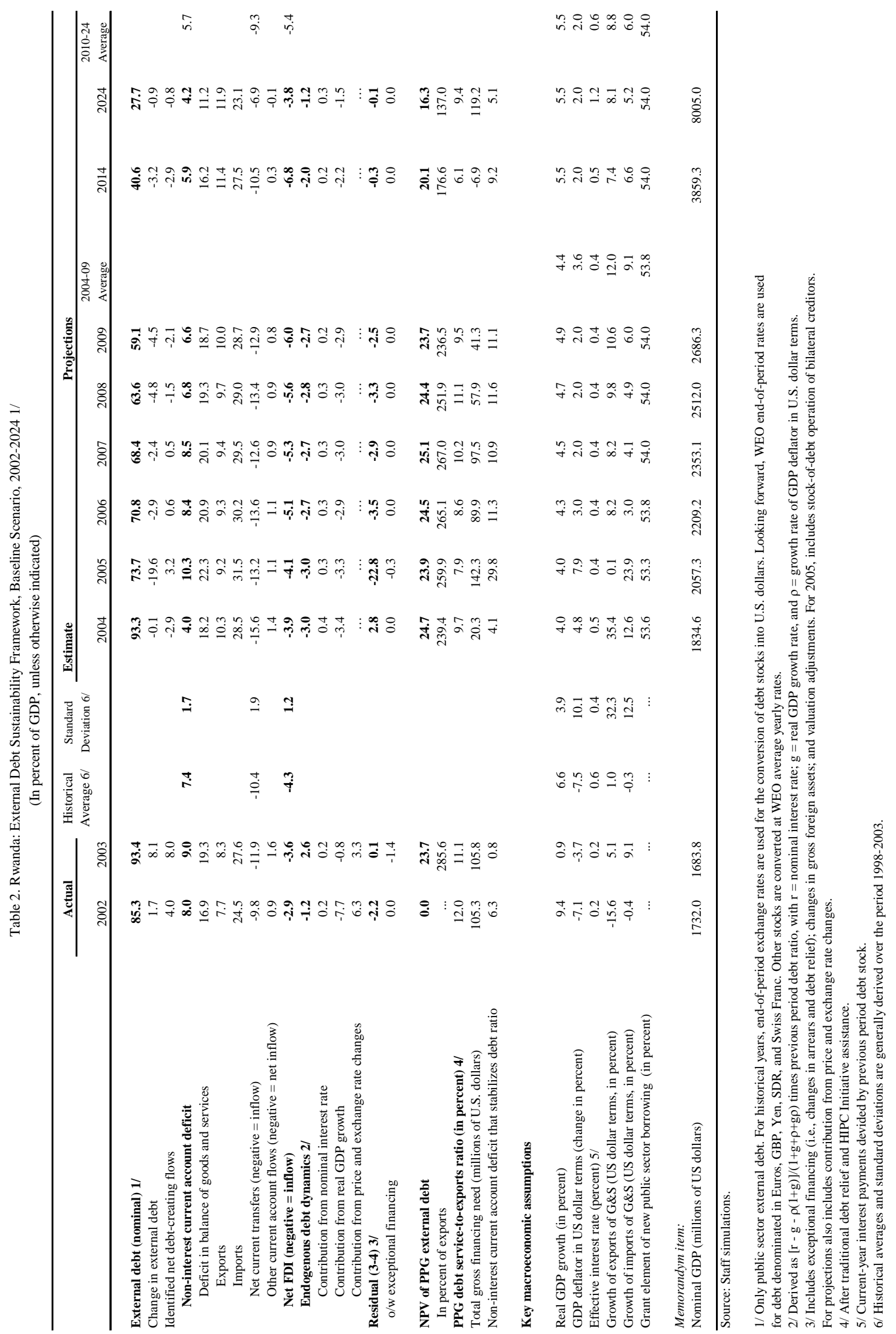


Table 3. Rwanda: Sensitivity Analyses for Key Indicators of Public and Publicly Guaranteed External Debt, 2004-24 (In percent)

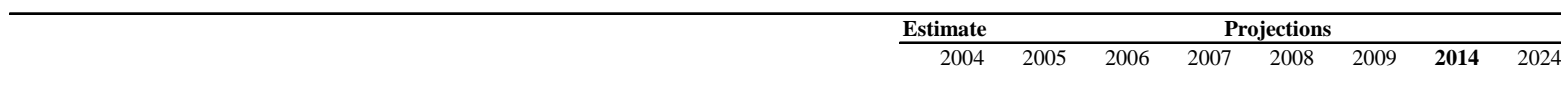

NPV of debt-to-GDP ratio

Baseline

A. Alternative Scenarios

A1. Key variables at their historical averages in 2005-24 1/

A2. New public sector loans on less favorable terms in 2005-24 2/

\section{B. Bound Tests}

B1. Real GDP growth at historical average minus one standard deviation in 2005-06 B2. Export value growth at historical average minus one standard deviation in 2005-06 3/ B3. US dollar GDP deflator at historical average minus one standard deviation in 2005-06 B4. Net non-debt creating flows at historical average minus one standard deviation in 2005-06 4/ B5. Combination of B1-B4 using one-half standard deviation shocks B6. One-time 30 percent nominal depreciation relative to the baseline in $20055 /$

$\begin{array}{rrrrrrrr}25 & 24 & 25 & 25 & 24 & 24 & \mathbf{2 0} & 16 \\ & & & & & & & \\ 25 & 26 & 29 & 32 & 35 & 39 & \mathbf{6 5} & 117 \\ 25 & 25 & 26 & 28 & 28 & 27 & \mathbf{2 4} & 24 \\ & & & & & & & \\ & & & & & & & \\ 25 & 24 & 25 & 25 & 25 & 24 & \mathbf{2 0} & 17 \\ 25 & 25 & 27 & 28 & 27 & 26 & \mathbf{2 2} & 17 \\ 25 & 29 & 35 & 36 & 35 & 34 & \mathbf{2 9} & 23 \\ 25 & 26 & 30 & 30 & 30 & 29 & \mathbf{2 4} & 18 \\ 25 & 31 & 42 & 42 & 41 & 40 & \mathbf{3 3} & 24 \\ 25 & 33 & 34 & 35 & 34 & 33 & \mathbf{2 8} & 23\end{array}$

Baseline

NPV of debt-to-exports ratio

\section{A. Alternative Scenarios}

A1. Key variables at their historical averages in 2005-241/ A2. New public sector loans on less favorable terms in 2005-24 2/

$\begin{array}{llllllll}239 & 260 & 265 & 267 & 252 & 237 & \mathbf{1 7 7} & 137 \\ & & & & & & & \\ 239 & 287 & 316 & 340 & 365 & 391 & \mathbf{5 6 8} & 983 \\ 239 & 269 & 286 & 298 & 285 & 272 & \mathbf{2 1 5} & 200\end{array}$

B. Bound Tests

B1. Real GDP growth at historical average minus one standard deviation in 2005-06 B2. Export value growth at historical average minus one standard deviation in 2005-06 3/ B3. US dollar GDP deflator at historical average minus one standard deviation in 2005-06 B4. Net non-debt creating flows at historical average minus one standard deviation in 2005-06 4/ B5. Combination of B1-B4 using one-half standard deviation shocks B6. One-time 30 percent nominal depreciation relative to the baseline in 2005 5/

Debt service ratio

\section{Baseline}

\section{A. Alternative Scenarios}

A1. Key variables at their historical averages in 2005-24 1/

A2. New public sector loans on less favorable terms in 2005-24 2/

$\begin{array}{llllllll}239 & 260 & 265 & 267 & 252 & 237 & \mathbf{1 7 7} & 137 \\ 239 & 329 & 473 & 474 & 448 & 421 & \mathbf{3 1 1} & 231 \\ 239 & 260 & 265 & 267 & 252 & 237 & \mathbf{1 7 7} & 137 \\ 239 & 286 & 324 & 323 & 305 & 287 & \mathbf{2 1 0} & 150 \\ 239 & 317 & 437 & 437 & 412 & 387 & \mathbf{2 8 3} & 198 \\ 239 & 260 & 265 & 267 & 252 & 237 & \mathbf{1 7 7} & 137\end{array}$

\section{B. Bound Tests}

B1. Real GDP growth at historical average minus one standard deviation in 2005-06 B2. Export value growth at historical average minus one standard deviation in 2005-06 3/ B3. US dollar GDP deflator at historical average minus one standard deviation in 2005-06 B4. Net non-debt creating flows at historical average minus one standard deviation in 2005-06 4/ B5. Combination of B1-B4 using one-half standard deviation shocks B6. One-time 30 percent nominal depreciation relative to the baseline in 2005 5/

$\begin{array}{rrrrrrrr}10 & 8 & 9 & 10 & 11 & 10 & \mathbf{6} & 9 \\ & & & & & & & \\ 10 & 9 & 10 & 13 & 16 & 15 & \mathbf{1 7} & 65 \\ 10 & 8 & 8 & 11 & 13 & 11 & \mathbf{8} & 12\end{array}$

Memorandum item:

Grant element assumed on residual financing (i.e., financing required above baseline) 6/

$\begin{array}{rrrrrrrr}10 & 8 & 9 & 10 & 11 & 10 & \mathbf{7} & 9 \\ 10 & 10 & 14 & 17 & 19 & 16 & \mathbf{1 3} & 15 \\ 10 & 8 & 9 & 10 & 11 & 10 & \mathbf{7} & 9 \\ 10 & 8 & 9 & 11 & 12 & 10 & \mathbf{9} & 10 \\ 10 & 9 & 12 & 15 & 16 & 14 & \mathbf{1 2} & 13 \\ 10 & 8 & 9 & 10 & 11 & 10 & \mathbf{7} & 9 \\ & & & & & & & \\ 53 & 53 & 53 & 53 & 53 & 53 & \mathbf{5 3} & 53\end{array}$

Source: Staff projections and simulations.

1/ Variables include real GDP growth, growth of GDP deflator (in U.S. dollar terms), non-interest current account in percent of GDP, and non-debt creating flows.

2/ Assumes that the interest rate on new borrowing is by 2 percentage points higher than in the baseline., while grace and maturity periods are the same as in the baseline. 3/ Exports values are assumed to remain permanently at the lower level, but the current account as a share of GDP is assumed to return to its baseline level after the shock (implicitly assuming an offsetting adjustment in import levels).

4/ Includes official and private transfers and FDI.

5/ Depreciation is defined as percentage decline in dollar/local currency rate, such that it never exceeds 100 percent.

6/ Applies to all stress scenarios except for A2 (less favorable financing) in which the terms on all new financing are as specified in footnote 2. 
Figure 1. Rwanda: Indicators of Public and Publicly Guaranteed External Debt Under Alternative Scenarios, 2004-2024

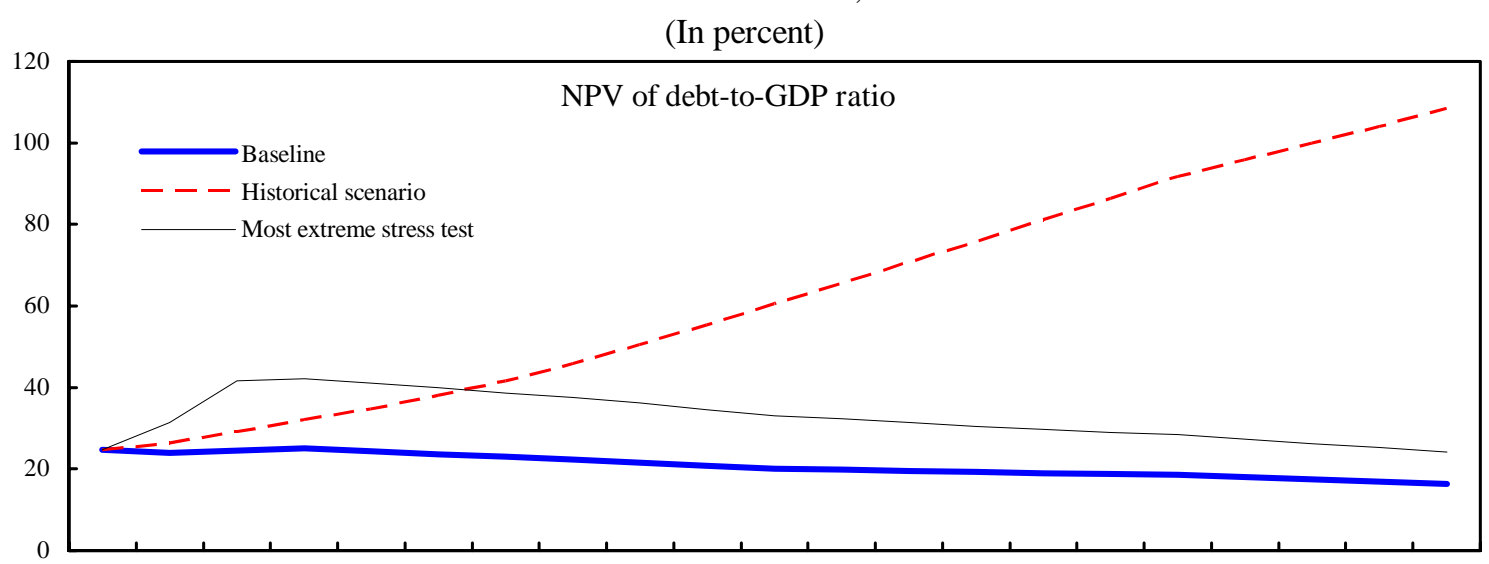

200420052006200720082009201020112012201320142015201620172018201920202021202220232024

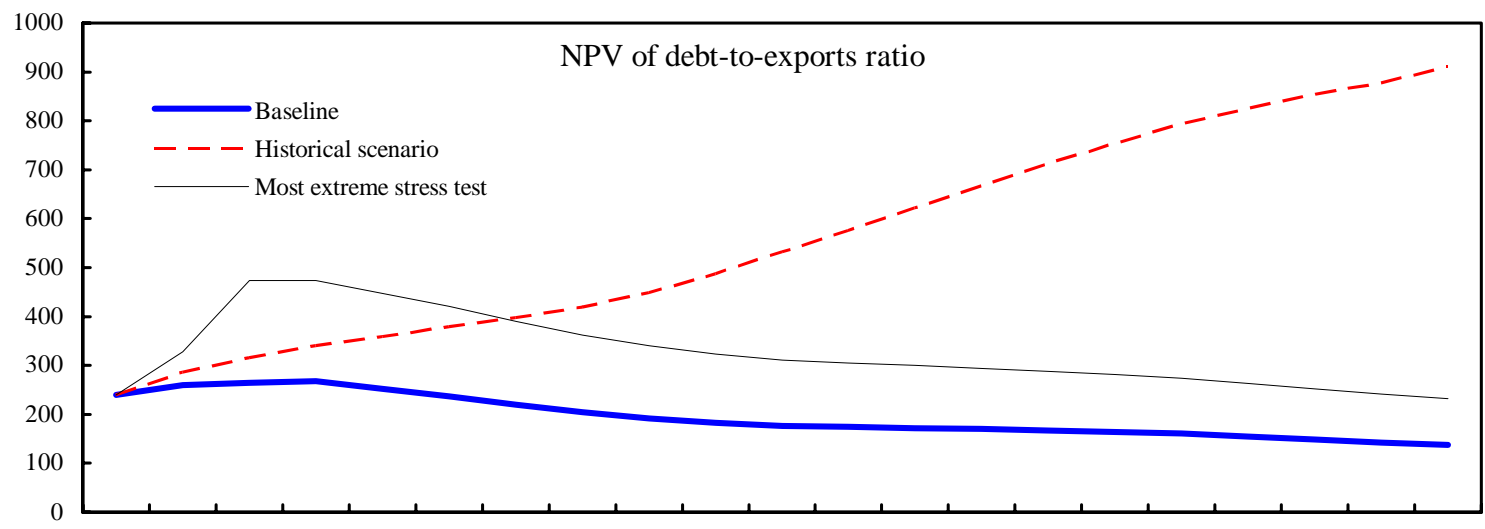

200420052006200720082009201020112012201320142015201620172018201920202021202220232024

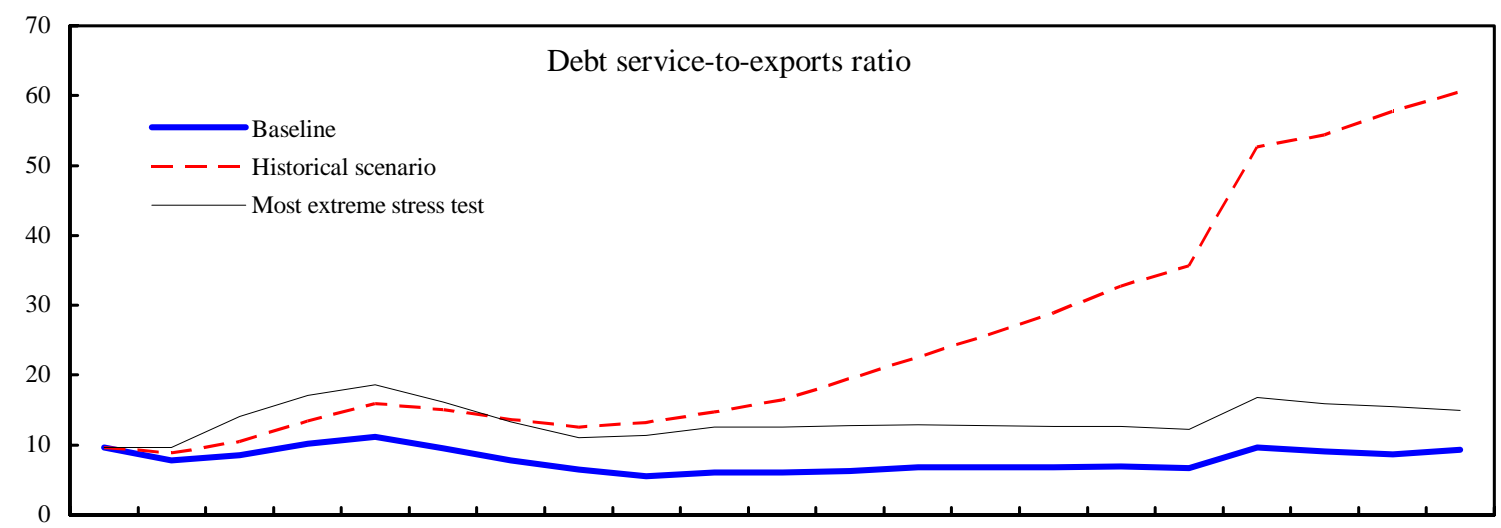

200420052006200720082009201020112012201320142015201620172018201920202021202220232024

Source: Staff projections and simulations. 